NBER WORKING PAPER SERIES

INTERNATIONAL EVIDENCE ON WELL-BEING

David G. Blanchflower

Working Paper 14318

http://www.nber.org/papers/w14318

NATIONAL BUREAU OF ECONOMIC RESEARCH
1050 Massachusetts Avenue
Cambridge, MA 02138
September 2008

I thank Andrew Clark, Dick Easterlin, Richard Freeman, Alan Krueger, Andrew Oswald, Jon Skinner, Alois Stutzer and Justin Wolfers and participants at the NBER Conference on National Time Accounts for helpful comments and suggestions. The views expressed herein are those of the author(s) and do not necessarily reflect the views of the National Bureau of Economic Research.

NBER working papers are circulated for discussion and comment purposes. They have not been peerreviewed or been subject to the review by the NBER Board of Directors that accompanies official NBER publications.

(C) 2008 by David G. Blanchflower. All rights reserved. Short sections of text, not to exceed two paragraphs, may be quoted without explicit permission provided that full credit, including $\odot$ notice, is given to the source. 
International evidence on well-being

David G. Blanchflower

NBER Working Paper No. 14318

September 2008

JEL No. I1,J0

\begin{abstract}
$\underline{\text { ABSTRACT }}$
National Time Accounting is a way of measuring society's well-being, based on time use. Its explicit form is the U-index, for "unpleasant" or "undesirable", which measures the proportion of time an individual spends in an unpleasant state. In this paper I review cross-country evidence on happiness and life satisfaction and consider whether these data will likely be replaced by the U-index. I find that first, that there are many similarities. According to both measures happiness is higher for the more educated, for married people, for those with higher income and for whites and lower for the unemployed; is U-shaped in age and un-trended over time in the USA although they are trended up in a number of EU countries and especially so in developing countries. Equivalent results are found using self-reported unhappiness data. Second, there is a large body of data on happiness that is unavailable on the U-index. For example, according to happiness research well-being across nations is lower the higher is the unemployment rate, the current inflation rate and the highest inflation rate in a person's adult life. Higher inequality also lowers happiness. Third, we know little about the predictive power of the U-index. Happiness and life satisfaction data seem able to forecast migration flows. Fourth, happy people are particularly optimistic about the future. Fifth, according to the happiness data the US ranks above France but the U-index suggests the reverse.
\end{abstract}

David G. Blanchflower

Bruce V. Rauner Professor of Economics

309B Silsby Hall

Dartmouth College

Hanover, NH 03755-3514

and NBER

david.g.blanchflower@dartmouth.edu 
National Time Accounting (NTA) as propounded by Krueger, Kahneman, Schkade, Schwarz and Stone (2007) - henceforth K2S3 - is a way of measuring society's well-being, based on time use. It is a set of methods for measuring, comparing and analyzing the way people spend their time, across countries, over historical time, or between groups of people within a country at a given time. The arguments for NTA build on earlier work in Kahneman et al (2004a, b) and Kahneman and Krueger (2006). K2S3 argue that NTA should be seen as a compliment to the National Income Accounts, not a substitute. Like the National Income Accounts, K2S3 accept that NTA "is also incomplete, providing a partial measure of society's well-being". However, national time accounting, as K2S3 note, "misses people's general sense of satisfaction or fulfillment with their lives as a whole, apart from moment to moment feelings" (p.4, 2007).

K2S3 propose an index, called the U-index (for "unpleasant" or "undesirable") which is designed to measure the proportion of time an individual spends in an unpleasant state. The first step in computing the U-index is to determine whether an episode is unpleasant or pleasant. An episode is classified as unpleasant by $\mathrm{K} 2 \mathrm{~S} 3$ if the most intense feeling reported for that episode is a negative one -- that is, if the maximum rating on any of the negative affect dimensions is strictly greater than the maximum of rating of the positive affect dimensions. Once they have categorized episodes as unpleasant or pleasant, the U-index is defined by $\mathrm{K} 2 \mathrm{~S} 3$ as the fraction of an individual's waking time that is spent in an unpleasant state. The U-index can be computed for each individual (what proportion of the time is this person in an unpleasant emotional state?), and averaged over a sample of individuals. There does seem to be some differences in the paper on how the U-index is actually calculated. For example, in K2S3's Table 5.2 the U-index is defined as where 'stressed, sad or pain exceeded happy whereas in their Table 8.2 it is defined as the 'maximum of tense, blue and angry being strictly greater than the rating of happy'. 
It is apparent that $\mathrm{K} 2 \mathrm{~S} 3$ believe their index is an improvement on the use of data on life satisfaction and happiness, which they suggest has a number of weaknesses. In Kahneman et al (2004) these same authors have criticized the use of such data because they argue that, there are (i) surprisingly small effects of circumstances on well-being (e.g., income, marital status, etc.);

(ii) large differences in the level of life satisfaction in various countries which they regard as 'implausibly large'. They go on to argue that, "..reports of life satisfaction are influenced by manipulations of current mood and of the immediate context, including earlier questions on a survey that cause particular domains of life to be temporarily salient. Satisfaction with life and with particular domains (e.g., income, work) is also affected by comparisons with other people and with past experiences. The same experience of pleasure or displeasure can be reported differently, depending on the standard to which it is compared and the context." (Kahneman et al 2004, p. 430)

Indeed, Kahneman and Krueger (2006) argued that well-being measures are best described as “... a global retrospective judgment, which in most cases is constructed only when asked and is determined in part by the respondent's current mood and memory, and by the immediate context." Frey and Stutzer (2005) have a rather different view.

"As subjective survey data are based on individuals' judgments, they are, of course, prone to a multitude of systematic and non-systematic biases. The relevance of reporting errors, however, depends on the intended usage of the data. Often, the main use of happiness measures is not to compare levels in an absolute sense, but rather to seek to identify the determinants of happiness. For that purpose, it is neither necessary to assume that reported subjective well-being is cardinally measurable, nor that it is interpersonally comparable. Higher reports of subjective well-being for one and the same individual has solely to reflect that she or he experiences more true inner positive feelings" (2005, pp. 208-209).

In the same vein Di Tella and MacCulloch (2007) note, "one would expect that such small shocks can be treated as noise in regression analyses". Consistent with this, however, Krueger and Schkade (2007) have reported that

"..overall life satisfaction measures...exhibited test-retest correlations in the range of $.50-.70$. While these figures are lower than the reliability ratios typically found for education, income and many other common micro economic variables, they are probably sufficiently high to support much of the research that is currently being undertaken on subjective well-being, particularly in cases where group 
means are being compared (e.g. rich vs. poor, employed vs. unemployed) and the benefits of statistical aggregation apply" (2007, p.23).

In their earliest empirical analysis, Kahneman and Kruger (2006) calculated a U-index using data from a sample of 909 working women in Texas and showed that those who report less satisfaction with their lives spend a greater fraction of their time in an unpleasant state. Of the respondents who reported they were 'not at all satisfied', 49\% of their time was spent in an unpleasant state, compared with $11 \%$ who said they were 'very satisfied'. The authors also found that those who score in the top third on a depression scale spent $31 \%$ of their time in an unpleasant state whereas those who score in the bottom third on the depression scale spent $13 \%$ of their time in an unpleasant state. K2S3 extend this work and report a comparison of the Uindex based on data they collected in the US and France - and I understand that results from Denmark are coming shortly. K2S3 sampled 810 women in Columbus, Ohio and 820 women in Rennes, France, in the spring of 2005 and obtained information on both life satisfaction and their U-index. The American women were twice as likely to say they were very satisfied with their lives as are the French women (26 percent versus 13 percent). Furthermore, assigning a number from 1 to 4 indicating life satisfaction also indicated that the Americans are significantly more satisfied, on average. In contrast to reported life satisfaction, the U-index is 2.8 percentage points lower in the French sample (16\%) than in the American sample $(18.8 \%)$. Thus, the French, according to K2S3, appear to spend less of their time engaged in unpleasant activities (i.e., activities in which the dominant feeling is a negative one) than do the Americans in their samples. Moreover, national time-use data examined by K2S3 indicated that the French spend relatively more of their time engaged in activities that tend to yield more pleasure than do Americans. 
The U-index relates to a relatively short period of time. Hence, there are a number of things the U-index does not measure - it appears to miss more general factors likely to impact a citizen's overall well-being. Examples, by country, include the fact that young people have been rioting on the streets of Paris (the UK Daily Telegraph headline read 'Test for Sarkozy as Paris riots continue', November $\left.27^{\text {th }}, 2007\right)$, the French soccer team has won the World Cup or the English team has been knocked out of Euro 2008, or that the country is at war in Iraq and Afghanistan, or there has been a terrorist attack or a hurricane or even forest fires in Malibu or floods in New Orleans? These may well be missed by the U-index while likely being picked up in happiness or life satisfaction measures which relate to a more general feeling of happiness. It remains unclear whether an increase in unemployment, inflation or inequality or a decline in growth, or a drop in the stock market or a rise in the possibility of recession the following year would raise the U-index? Does the U-index predict the outcomes of elections or migration flows or anything at all for that matter? As I will outline in more detail below, it certainly seems that these factors impact our measures of well-being.

In what follows I provide a somewhat selective review of evidence on well-being using cross-country data and try to provide a framework for reconciling the findings from this work with those from the U-index. I present the main findings from responses on both happiness and life satisfaction as well as on unhappiness, hypertension, stress, depression, anxiety and pain from a considerable number of cross-country data sources. I also explore the results when happiness questions are based on what happens over the preceding week and find slightly weaker results. I then move on to look at how macro variables such as the national unemployment rate, inflation and output impact life satisfaction. I find evidence that a one percentage point increase in unemployment lowers happiness more than an equivalent increase in inflation and that the 
highest level of inflation experienced as an adult lowers happiness further. Further, I show that life satisfaction levels in East European countries predict flows of workers to the UK and Ireland. Finally, I examine individual's expectations and show that happy people are particularly optimistic about the future, both for themselves and the economy. Subjective well-being data are clearly correlated with observable phenomena (Oswald, 1997).

\section{Happiness and Life satisfaction}

Data on happiness and life satisfaction in particular are now available for many countries and for a large number of time periods. As with the U-index it is possible to average these already existing data across individuals and countries to form a National Happiness Index (NHI) to generate a measure national well-being, which would be a simple and cheap alternative to K2S3's proposed NTA. A crucial question is whether or not K2S3's proposed U-index an improvement over an NHI? As I lay out in detail below, there are many similarities between the two indices in terms of their determinants. The main differences relate to country rankings.

Before presenting data on happiness and life satisfaction in seminars to the many skeptical economists who don't believe you can, or even should, measure well-being - although there are less of that ilk these days - I explain that the data have been validated by researchers in other disciplines. I tell them that the answers to happiness and life satisfaction questions are well correlated with a number of important factors (for references see Di Tella and MacCulloch, 2007).

1. Objective characteristics such as unemployment.

2. Assessments of the person's happiness by friends and family members.

3. Assessments of the person's happiness by his or her spouse.

4. Heart rate and blood-pressure measures of response to stress. 
5. The risk of coronary heart disease

6. Duration of authentic or so-called Duchenne smiles. A Duchenne smile occurs when both the zygomatic major and obicularus orus facial muscles fire, and human beings identify these as 'genuine' smiles (see Ekman, Friesen and O'Sullivan (1988) and Ekman, Davidson and Friesen, (1990)).

7. Skin-resistance measures of response to stress.

8. Electroencephelogram measures of prefrontal brain activity.

Happiness and life satisfaction data are easy to obtain at the macro level as the data are downloadable from the World Database of Happiness for over 100 countries. Most surveys now use a common format for the questions. In general economists have focused on modelling two fairly simple questions, one on life satisfaction and one on happiness. These are typically asked as follows.

Q1. 3-step happiness - e.g. from the US General Social Survey (GSS)

"Taken all together, how would you say things are these days - would you say that you are very happy, pretty happy or not too happy?"

Q2. 4-step life satisfaction - e.g. from the European Eurobarometer Surveys

"On the whole, are you very satisfied, fairly satisfied, not very satisfied, or not at all satisfied with the life you lead?"

The micro data on happiness are easily obtainable from most data archives including ICPSR for the GSS, the Data Archive at the University of Essex and ZACAT in Germany for the Eurobarometers, ISSP, European Social Survey, BHPS, GSOEP, European Quality of Life Survey, European Social Surveys etc.. Life satisfaction data are also now available annually from the Latinobarometers while happiness data is available annually in the Asianbarometers (Blanchflower and Oswald, 2007). Several of the data series extend back at least to the early 1970s. Many of the data sets cover several countries. 
Economists like to run regressions, so by now the standard econometric approach taken by economists is to use micro data on happiness and/or life satisfaction to estimate an ordered logit or an Ordinary Least Squares (OLS) regression with the coding such that the higher the number the more satisfied an individual is (e.g. Blanchflower and Oswald, 2004). Generally, it makes little or no difference if you use an OLS or an ordered logit. The results are similar - but not identical - for happiness and life satisfaction. The main, ceteris paribus, findings from happiness and life satisfaction equations across countries and time are as follows.

\section{Well-being is higher among:}

Women

Married people

The highly educated

Active involvement in religion

The healthy

Those with high income

The young and the old - U-shaped in age

The self-employed

People with low blood pressure

The sexually active and especially those who have sex at least once a week

Those with one sex partner

Those without children

\section{Well-being is lower among:}

Newly divorced and separated people

Adults in their mid to late 40s

The unemployed

Immigrants and minorities

Those in poor health

Commuters

People with high blood pressure

The less educated

The poor

The sexually inactive

Those with children

There have been a number of recent surveys of the happiness literature including Clark et al (2007); Frey and Stutzer (2002a, b) and Di Tella and MacCulloch (2006) which provide 
discussions of the relevant issues. Recent findings from the statistical happiness research include the following:

(i) For a person, money does buy a reasonable amount of happiness. But it is useful to keep this in perspective. Very loosely, for the typical individual, a doubling of salary makes a lot less difference than life events like marriage or unemployment.

(ii) For a nation, things are different. Whole countries, at least in the West where almost all the research has been done, do not seem to get much happier as they get richer.

(iii) Happiness is U-shaped in age. Women report higher well-being than men. Two of the biggest negatives in life are unemployment and divorce. Education is associated with high reported levels of happiness even after controlling for income.

(iv) Happy people are less likely to commit suicide (Koivuma et al, 2001).

(v) The structure of a happiness equation has the same general form in each industrialized country (and possibly in developing nations, though only a small amount of evidence has so far been collected). In other words, the broad statistical patterns look the same in France, Britain and the United States. As Di Tella and MacCulloch note "well-being equations, (where happiness and life satisfaction scores are correlated with the demographic characteristics of the respondents) are broadly "similar" across countries, (is) an unlikely outcome if the data contained just noise" (2007, p.9).

(vi) There is some evidence that the same is true in panels of people (that is, in longitudinal data). Particularly useful evidence comes from looking at windfalls, like lottery wins.

(vii) There is adaptation. Good and bad life events wear off, at least partially, as people get used to them. 
(vii) Relative things matter a great deal. First, in experiments, people care about how they are treated compared to those who are like them, and in the laboratory will even pay to hurt others to restore what they see as fairness. Second, in large statistical studies, reported well-being depends on a person's wage relative to an average or 'comparison' wage including Blanchflower and Oswald (2004); Ferrer-i-Carbonell (2005); Di Tella et al (2005) and Luttmer (2005). Third, wage inequality depresses reported happiness in a region or nation (controlling for many variables), but the effect is not large (Alesina et al, 2004). Some of these patterns are visible in raw data alone. Strong correlations with income, marriage and unemployment are noticeable.

For the United States there seems to be relatively little evidence that despite rising affluence, happiness or life satisfaction have trended up much over time (Blanchflower and Oswald (2004). For example, in the 2006 GSS, $13.1 \%$ of respondents said they were not too happy, $56.1 \%$ pretty happy and $30.8 \%$ very happy. In 1972 , the first year happiness data are available the numbers were $16.5 \%, 53.2 \%$ and $30.3 \%$ respectively. As can be seen from Figure 1, average happiness levels for the US are flat, while real GDP per capita has risen. It is also apparent from Table 7.3 of $\mathrm{K} 2 \mathrm{~S} 3$ that their U-index based on time in various activities each year is also flat over time.

$\begin{array}{lcclcll} & 1965-66 & 1975-76 & 1985 & 1992-94 & 2003 & 2005 \\ \text { All } & 20.1 \% & 19.5 \% & 19.5 \% & 20.0 \% & 19.3 \% & 19.6 \% \\ \text { Men } & 20.9 & 20.4 & 20.1 & 20.2 & 19.6 & 19.9 \\ \text { Women } & 19.4 & 18.7 & 19.0 & 19.8 & 19.2 & 19.4\end{array}$

The picture is rather more mixed among European countries. For example, in Figure $2 \mathrm{a}$ and $2 \mathrm{~b}$ there is some sign of a strong long-run upward trend in Italy and to a lesser extent in Denmark, and France while the data are relatively flat in the Netherlands, Germany, the UK and Ireland. In contrast, Belgium and Portugal have significant downward trends (results not reported). Note that happiness levels are generally high in Denmark and low in Italy and France. In addition, 
Frey and Stutzer (2002b) have shown that the time trend in life satisfaction in Japan was flat between 1958 and 1991 over the period when GDP per capita rose by a factor of six.

There is evidence however of upward trends in Eastern European countries, Turkey and South American countries over the recent past. Table 1 reports the distribution of life satisfaction scores for countries from Western and Eastern Europe and from Latin America over the recent past. Among the seventeen Western European countries since the turn of the century, five have seen satisfaction broadly flat (Denmark; Greece: Ireland; Spain and the UK); five have seen increases (Belgium; Finland; France; Luxembourg and Sweden) while seven have seen declines (Austria; Germany; Italy; Japan; Netherlands; Portugal and the USA). In contrast, with the exception of Hungary, all of the Eastern European countries plus Turkey have all seen increases as is the case for all the Latin American countries from 1997. ${ }^{1}$ There is some consistent evidence also that the wellbeing of the young $(<30)$ has risen over time in both the USA and Europe (Blanchflower and Oswald, 2000). The rise is mostly among the unmarried. We found that this upward trend is not explained by changing education or work, falling discrimination or rise of youth-oriented consumer goods.

There is some evidence of convergence over time in the happiness of men and women in the US as women have become less happy (Blanchflower and Oswald, 2004a). Stevenson and Wolfers (2007) find that the relative decline in women's well-being holds for both working and stay-at-home moms, for those married and divorced, for the old and the young, and across the education distribution. The relative decline in well-being holds across various datasets, and for whether one asks about happiness or life satisfaction. Stevenson and Wolfers find that the

\footnotetext{
${ }^{1}$ Easterlin and Zimmermann (2008) suggest that the observed increases in happiness in East Germany have arisen following a noticeable drop in life satisfaction at the time of unification (Blanchflower, 2001), so the rise is largely a recovery to pre-transition levels. In private communication Dick Easterlin has further suggested, based on his recent work, that the collapse and recovery of life satisfaction is typically the case for the European transition countries.
} 
exception is that this African-American women have become happier over this period as have African-American men and there has been little consistent change in the gender happiness gap among African Americans over this period. As with U.S. women, Stevenson and Wolfers find that the well-being of European women has declined relative to men. However, while U.S. women also experienced an absolute decline in well-being, the subjective well-being of European men and women has risen over time.

There is also intriguing new evidence that high frequency happiness data yields information about preferences. Kimball et al (2006), for example, showed that happiness dipped significantly the first week of September 2005, after the seriousness of the damage done by Hurricane Katrina started to become apparent. The dip in happiness lasted two or three weeks and was especially apparent in the South Central region, closest to the devastated area.

\section{The U-index}

The first column of Table 2 is taken from K2S3 and reports their U-index, which should be thought of as the inverse of a subjective wellbeing or happiness index. The higher the U-index the more unhappy the person is. There is little difference by gender; blacks are especially unhappy; the poor are unhappy as are the least educated. Unhappiness declines with age and is particularly low for the married and high for the widowed. How do these findings compare with those found using happiness and life satisfaction data? Column two presents the proportion of people in the USA from the General Social Surveys of 2000-2006 who say they are very happy (from a 1-3 scale) while in column 3 the proportion of Europeans from the 2000-2006 Eurobarometers saying they were very satisfied and in the final column for the 2005/2006 Latinobarometers who say they are very satisfied, both on a 1-4 scale, are reported. ${ }^{2}$ Here a

\footnotetext{
2 The countries covered in these Eurobarometers are Austria; Belgium; Bulgaria; Croatia; Cyprus; Czech Republic; Denmark; Estonia; Finland; France; Germany; Greece; Hungary; Ireland; Italy; Latvia; Lithuania; Luxembourg;
} 
larger proportion means happier and is the inverse of the U-index. Interestingly the results are very similar in all four columns. Happiness is higher for the more educated, for married people, for those with higher income and for whites.

Happiness does rise with age in the USA but once controls are included happiness is Ushaped in age (Blanchflower and Oswald, 2007b). It is U-shaped in age in both the European and Latin American countries even in the raw data and when controls are included (Blanchflower and Oswald, 2007b). ${ }^{3}$ This result is confirmed by K2S3 in their Table 7.4 where unhappiness seems to follow an inverted U-shape. ${ }^{4}$ We explore this U-shape in age in more detail below. The patterns across individuals are essentially the same then from SWB and NTA in the USA, Latin America and Europe. It turns out that the happiness derived from sex in both SWB studies and in U-index studies is especially high. (Blanchflower and Oswald, 2004b) found that sexual activity enters strongly positively in happiness equations. ${ }^{5}$ Indeed, in Kahneman and Krueger,

Malta; Netherlands; Norway; Poland; Portugal; Romania; Slovakia; Slovenia; Spain; Sweden; Turkey and the UK. The Latinobarometer covers Argentina; Bolivia; Brazil; Colombia; Costa Rica; Chile; Dominican Republic; Ecuador; El Salvador; Guatemala; Honduras; Mexico; Nicaragua; Panama; Paraguay; Peru; Uruguay and Venezuela.

${ }^{3}$ As Clark (2007) notes, this finding is repeated in happiness equations in Blanchflower and Oswald (2004); Clark (2005); Clark and Oswald (1994); Clark et al. (1996); Di Tella et al. (2001); Frey and Stutzer (2002a); Frijters et al. (2004); Gerdtham and Johannesson (2001); Graham (2005); Helliwell (2003); Kingdon and Knight (2007); Lelkes (2006); Oswald (1997); Powdthavee (2005); Propper et al. (2005); Sanfey and Teksoz (2007); Senik (2004); Shields and Wheatley Price (2005); Theodossiou (1998); Uppal (2006); Van Praag and Ferrer-i-Carbonell (2004) and Winkelmann and Winkelmann (1998).

${ }^{4}$ Blanchflower and Oswald (2007b) find that a robust U-shape in age in happiness/life satisfaction is found in seventy-two countries - Albania; Argentina; Australia; Azerbaijan; Belarus; Belgium; Bosnia; Brazil; Brunei; Bulgaria; Cambodia; Canada; Chile; China; Colombia; Costa Rica; Croatia; Czech Republic; Denmark; Dominican Republic; Ecuador; El Salvador; Estonia; Finland; France; Germany; Greece; Honduras; Hungary; Iceland; Iraq; Ireland; Israel; Italy; Japan; Kyrgyzstan; Laos; Latvia; Lithuania; Luxembourg; Macedonia; Malta; Mexico; Myanmar; Netherlands; Nicaragua; Nigeria; Norway; Paraguay; Peru; Philippines; Poland; Portugal; Puerto Rico; Romania; Russia; Serbia; Singapore; Slovakia; South Africa; South Korea; Spain; Sweden; Switzerland; Tanzania; Turkey; United Kingdom; Ukraine; Uruguay; USA; Uzbekistan and Zimbabwe.

${ }^{5}$ Blanchflower and Oswald (2004b) found that higher income does not buy more sex or more sexual partners. Married people have more sex than those who are single, divorced, widowed or separated. The happinessmaximizing number of sexual partners in the previous year is calculated to be 1. Highly educated females tend to have fewer sexual partners. Homosexuality has no statistically significant effect on happiness. 
(2006) and Kahneman et al (2004b), 'intimate relations' has the lowest rating (i.e. gives the most happiness) while commuting has the highest. Somewhat surprisingly, though in K2S3 'walking' gave more happiness than 'making love' among US women, although the reverse was the case among French women (Table 8.3)!

In section 8 of their paper $\mathrm{K} 2 \mathrm{~S} 3$ do some international comparisons of SWB in two "representative" cities, one in France and the other in the United States, and ask whether the standard measure of life satisfaction and the NTA yield the same conclusion concerning relative well-being. Specifically, they designed a survey to compare overall life satisfaction, time use, and recalled affective experience during episodes of the day for random samples of women in Rennes in France and Columbus, Ohio in the United States. These cities were selected because they argued that they represented "middle America" and "middle France". K2S3 also presented results using time allocation derived from national samples in the United States and France to extend their analysis beyond these two cities. The city sample consisted of 810 women in Columbus, Ohio and 820 women in Rennes, France. Respondents were invited to participate based on random-digit dialing in the Spring of 2005 and were paid approximately $\$ 75$ for their participation in both countries. The age range spanned 18 to 68 , and all participants spoke the country's dominant language at home. The Columbus sample was older (median age of 44 versus 39), more likely to be employed (75 percent versus 67 percent) and better educated (average of 15.2 years of schooling years versus 14.0) than the Rennes sample. In addition, the Rennes sample was more likely to be currently enrolled in school (16 percent versus 10 percent). The life satisfaction question was taken from the World Values Survey.

The distribution of reported life satisfaction in Columbus, $\mathrm{OH}$ and Rennes, France for women found by $\mathrm{K} 2 \mathrm{~S} 3$ is presented in the first two columns of part A of Table 3a using the 4- 
step life satisfaction scale. Life satisfaction is based on the question, "Taking all things together, how satisfied are you with your life as a whole these days - not at all satisfied, not very, fairly and very satisfied?" K2S3 found that American women reported higher levels of life satisfaction than the French did, whether the proportion who said they were very satisfied or the overall score is used. Yet they also found that, on average, the French spent their days in a more positive mood. Moreover, the national time-use data they used also indicated that the French spend relatively more of their time engaged in activities that tend to yield more pleasure than do Americans. Their results, they argue, "suggest that considerable caution is required in comparing standard life satisfaction data across populations with different cultures". In particular, the Americans seem to be more emphatic when reporting their well-being. The Uindex K2S3 suggests, "apparently overcomes this inclination".

Kahneman et al (2004 p. 430) have argued that differences in the SWB ratings of Denmark and France, for example, in the Eurobarometers are implausibly large, and they "raise additional doubts about the validity of global reports of subjective well-being, which may be susceptible to cultural differences in the norms that govern self descriptions". For example, in the Eurobarometers 2000-2006, the average distributions for life satisfaction for these two countries are as follows.

$\begin{array}{lccccc} & \text { not at all } & \text { not very } & \text { fairly } & \text { very } & \text { N } \\ & \text { satisfied } & \text { satisfied } & \text { satisfied } & \text { satisfied } & \\ \text { France } & 4 \% & 15 \% & 65 \% & 16 \% & 13,554 \\ \text { Denmark } & 1 \% & 3 \% & 33 \% & 63 \% & 13,718\end{array}$

Such differences are consistently repeated in multiple data sets, whether happiness or life satisfaction is used. It is clearly problematic to compare one country's happiness answers to those of another country. Nations have different languages and cultures, and in principle that may cause biases, perhaps large ones, in happiness surveys. At this point in research on 
subjective well-being, the size of any bias is not known, and there is no accepted way to correct the data, although the literature has made some progress in exploring this issue (for instance, by looking inside a nation like Switzerland at sub-groups with different languages). In the long run, research into ways to difference out country fixed-effects will no doubt be done and the work of K2S3 in this regard is obviously important. The strong well-being performance in some happiness surveys of countries such as Mexico and Brazil in the 2002 ISSP, for example, (Blanchflower and Oswald, 2005), may or may not ultimately be viewed as completely accurate. In Blanchflower and Oswald (2005), one check was done by comparing happiness in the English speaking nations of Great Britain, Ireland, New Zealand, Northern Ireland and the United States. The main attraction is that this automatically avoids translation problems. Moreover, this smaller group of nations has the advantage that they are likely to be more similar in culture and philosophical outlook, and that in turn may reduce other forms of bias in people's answers. However, it does appear that there is considerable stability in cross-country rankings of life satisfaction in English speaking countries (Blanchflower and Oswald, (2005, 2006); Leigh and Wolfers, (2006)).

\section{Econometric evidence on life satisfaction and happiness}

As I will show in more detail below there is also a great deal of stability in the rankings of European countries across a number of surveys including the Eurobarometers (1973-2006), European Quality of Life Survey (2003) and the European Social Survey (2002). Further, it seems that there is evidence from the World Values Survey and the International Social Survey Programme (2002) supporting a happiness ranking where the US is ranked above France as implied in K2S3's life satisfaction data rather than below it as implied by their U-index. In fact I am unable to find any data file where the ranking reverses as occurs with the U-index. The 
evidence is essentially the same whether we look at happiness, life satisfaction or health, family life or conversely, a variety of measures of unhappiness including measures of high blood pressure, stress, lack of sleep, pain and being 'down and depressed'.

Where feasible I present data comparing the US and France but there are only a few data files that include both countries so we make use of data from a number of European data files that allow a direct comparison with Denmark that will be included in K2S3's analysis shortly plus the UK, which is of particular interest to this author! In almost all of what follows the UK ranks above France: Denmark is mostly top of the happiness rankings in Europe, especially when life satisfaction is used. If we refer to Figures $2 \mathrm{a}$ and $2 \mathrm{~b}$ which are based on Eurobarometer data, Denmark ranks above the UK which itself ranks above France, in every year of data we have available. Indeed, based simply on life satisfaction averages France usually ranks below the large majority of the EU15. For example, in the raw data from the latest Eurobarometer available, \#65.2 for March-May 2006, France ranked fourteenth out of thirty countries. ${ }^{6}$ Controlling for a variety of characteristics over a long run of thirty years, France ranked seventeenth out of thirty. ${ }^{7}$

Columns 3-5 of part A of Table 3a report results using the most recent subset of the data from the Eurobarometers for 2000-2006 which shows that France ranks third behind Denmark

\footnotetext{
${ }^{6}$ Average life satisfaction scores were Denmark (3.61); Sweden (3.39); Luxembourg (3.39); Netherlands (3.36); Ireland (3.28); Finland (3.23); UK (3.19); Belgium (3.19); Cyprus (3.12); Slovenia (3.10); Spain (3.08); Austria (3.08); Turkish Cyprus (3.02); France (3.00); Malta (2.98); West Germany (2.95); Czech Republic (2.89); Italy (2.86); Turkey (2.85); Poland (2.79); Croatia (2.78); Estonia (2.72); East Germany (2.72); Greece (2.67); Slovakia (2.66); Lithuania (2.58); Latvia (2.56); Hungary (2.47); Portugal (2.44); Romania (2.31) and Bulgaria (1.97).

${ }^{7}$ When an ordered logit is run using these Eurobarometer data from 1973-2006 pooled across all member countries plus Candidate Countries Croatia, Norway and Turkey with a standard set of controls as in Table 8 column 5, the rankings are as follows with rank in parentheses Denmark (1); Netherlands (2); Norway (3); Sweden (4); Luxembourg (5); Ireland (6); UK (7); Finland (8); Belgium (9); Austria (10); Cyprus (11); Slovenia (12); Malta (13); Spain (14); Germany (15); Turkey (16); France (17); Czech Republic (18); Italy (19); Croatia (20); Poland (21); Portugal (22); Estonia (23); Greece (24); Slovakia (25); Latvia (26); Lithuania (27); Hungary (28); Romania (29); Bulgaria (30);
} 
and the UK. Part B of Table 3a presents data on women using the World Values Survey on a 10 point life satisfaction scale and replicates that ranking. Part $\mathrm{C}$ of the table uses data for men and women combined from the World Database of Happiness and which includes all four countries. Once again France ranks bottom, with Denmark second and the UK third with the USA at the top.

In the final part of Table 3a I present some macro-economic data on GDP per capita, the Gini coefficient and the most recent unemployment rate (Source; Labour Market Statistics First Release, ONS, November, 2007). In comparison with France the USA has a) a lower unemployment rate, b) higher GDP per capita c) higher Gini coefficient. France has especially high rates of long-term unemployment and youth unemployment. Denmark has an especially low unemployment rate and low Gini coefficient. Despite the well known difficulty of making suicide rates comparable across countries, it appears that the rates in France for both men and women are well above those for the USA. This is illustrated in Table $3 \mathrm{~b}$. This ranking is more consistent with SWB data rankings than it is with rankings based on NTA.

Happiness from a further source, the International Social Survey Programme (ISSP), which also contains data from the two countries, is also supportive of the fact that happiness in the USA is higher than it is in France. Data on the two countries are available in the 1998, 2001 and 2002 sweeps. In the first two sweeps happiness data is available on a four point scale in response to the question 'how happy are you with your life in general - not at all happy; not very happy, fairly happy and very happy'. Responses are as follows

\begin{tabular}{|c|c|c|c|c|c|c|}
\hline & not at all & not very & fairly & very & score & $\mathrm{N}$ \\
\hline 2001 USA & $1 \%$ & $7 \%$ & $51 \%$ & $41 \%$ & $3.3 \%$ & 1129 \\
\hline 1998 USA & $2 \%$ & $9 \%$ & $52 \%$ & $37 \%$ & $3.2 \%$ & 1272 \\
\hline 2001 France & $1 \%$ & $9 \%$ & $62 \%$ & $27 \%$ & $3.2 \%$ & 1330 \\
\hline 1998 France & $3 \%$ & $20 \%$ & $64 \%$ & $13 \%$ & $2.9 \%$ & 1082 \\
\hline
\end{tabular}


The overall score for the French increased between 1998 and 2001. In the 2002 ISSP responses were provided on a seven point scale and the US score is once again considerably higher than for the French for both men and women. As can be seen below the average score across respondents in the USA was higher for both men and women, however, the proportion very unhappy completely, very or fairly - was higher. For men in the USA $4.3 \%$ in this category compared with $3.1 \%$ in France while for women the numbers were $4.2 \%$ and 3.6\% respectively.

\section{USA}

Completely unhappy

Female

Very unhappy

Fairly unhappy

Neither

0.2

1.5

2.5

5.4

Fairly happy

Very happy

31.9

Completely happy

Score

$\mathrm{N}$

45.7

13.0

5.56

672

Male

All

0.0

1.2

3.1

6.8

36.3

41.6

11.1

5.47

488

0.1

1.4

2.8

6.0

33.7

44.0

12.2

5.52

1,160

\section{France}

Completely unhappy

Female

Male

All

Very unhappy

0.1

0.3

3.2

13.4

Neither

48.8

23.6

Very happy

10.7

Completely happy

5.24

$\mathrm{N}$

0.2

0.5

2.4

10.9

49.1

25.0

12.0

5.31

617
0.1

0.3

3.0

12.6

48.9

24.1

11.1

5.26

1,833

We now turn to the econometric evidence where we are able to hold constant a number of factors including labor market and marital status, age, gender and schooling. The rankings remain essentially unchanged.

Econometric evidence on the micro-determinants of happiness 
Rank orderings of the United States and France are consistent whether we examine happiness, life satisfaction or other variables relating to the family, no matter what the data file or year we examine. Table $4 \mathrm{a}$ and $4 \mathrm{~b}$ explores differences in happiness between the United States and France using the ISSP 1998, 2001 and 2002 data described above. ${ }^{8}$ In all three years of data the USA ranks above France, although there is some variation in the rankings across other countries. For example, the UK is above the USA in 1998 and 2001 but below it in 2002 and above Denmark in all three years while Denmark is below France in 2001. In most other data files we examine below Denmark ranks top in Europe, especially on life satisfaction. Columns 3 and 4 provide estimates of ordered logits estimating how satisfied the individual is with their family life. The idea here is to ensure the rankings are not driven by different interpretations of the word 'happy', although still potentially impacted by the reticence of the French to be emphatic when reporting their well-being. Rankings are similar to those based on happiness, with Americans more satisfied than the French. It does seem, however, that people in the USA value time with their families very highly. Interestingly, when individuals in the ISSP are asked whether they wished they could spend more time with their families, more than half of respondents reported they would like to spend 'much more time', compared with a third in France and the UK and a fifth in Denmark (Table 5).

It is appropriate to explore further the ranking by country using the SWB measures from other data files to see if the rankings are consistent and this is what is done in Tables 6-8 and it turns out they are. Table 6 uses data from eighty two countries from the four sweeps of the World Values Surveys of 1981-2004 on both life satisfaction and happiness. Ordered logits are

\footnotetext{
${ }^{8}$ The exact question asked is Q.17. 'If you were to consider your life in general, how happy or unhappy would you say you are, on the whole?' $-1=$ completely happy, $2=$ =very happy, $3=$ fairly happy, $4=$ =neither happy nor unhappy, $5=$ fairly unhappy, $6=$ very unhappy and $7=$ completely unhappy.
} 
estimated in columns 1 and 2 with the dependent variable life satisfaction with responses scored on a scale of 1-10 where 1 is least satisfied and 10 most satisfied. The sample size is just over a quarter of a million observations - only three country dummies are included with the remaining country dummies all excluded for simplicity. The first column only includes 19 year dummies and country dummies for France, Denmark, the UK and the USA with all other countries set as the omitted category for simplicity. Column 2 adds controls for age, gender, marital status and labor market status. Happiness is higher among the married (Zimmermann and Easterlin, 2006), the educated and especially low among unemployed (Blanchflower and Oswald, 2004a, b). In both columns the country ranking remains as follows - France, UK, USA and Denmark. In columns 3 and 4 the dependent variable is a 4-step happiness variable and the rankings are a little different - France, USA, UK and again Denmark at the top. These results are consistent with the findings of Veenhoven (2000) who examined the first three waves of the WVS and found that among the three possible ways of ranking countries based on responses of individuals on how happy they are, how satisfied they are and how they would rate their lives on a scale from the worst to the best possible life, the ranking stays roughly the same.

Table 7 uses data from another source, the European Quality of Life Study of 2003 $(\mathrm{n}=26,000)$, which obviously excludes the US, and follows a similar form but this time separate results are reported on a 10-step scale for life satisfaction and happiness. Data are also available on the individual's assessment of their overall health - on a five point scale: poor, fair, good, very good and excellent. Four separate controls for health status are included in column 2 for life satisfaction and column 5 for happiness along with a standard set of controls. Household income in Euros is also available in the data file which is the added, in natural logarithms, in columns 3 and 6 . This is the first time in a cross-country data file on happiness that income has 
been available in one currency (Euros). In all cases the rankings for the three main countries of interest are France, then the UK and finally Denmark highest ranked. East European countries have low levels of happiness (Blanchflower (2001), Sanfey and Teksoz (2007)); life satisfaction and happiness is U-shaped in age, minimizing in the mid-40s for life satisfaction and in the $50 \mathrm{~s}$ for happiness. Adding controls for income lowers the age minimum. Happiness rises with education and income whether health is controlled for or not. Married people and those living together as well as those in good health are particularly happy. The unemployed are especially unhappy (Blanchflower and Oswald, 2004; Carroll, 2007 for Australia and Hinks and Gruen, 2007 and Powdthavee, 2007 for South Africa).

Money buys happiness. Interestingly, and perhaps surprisingly from an economist's point of view, the coefficients on the other variables in Table 7's well-being equations hardly alter when income is controlled for. The amount of happiness bought by extra income is not as large as some would expect. To put this differently, the non-economic variables in happiness equations enter with large coefficients, relative to that on income. Following Blanchflower and Oswald (2004), Table 7, or its ordinary least squares equivalent (see Appendix Table A), can be used to do a form of happiness calculus. The relative size of any two coefficients provides information about how one variable would have to change to maintain constant well-being in the face of an alteration in the other variable. To 'compensate' for a major life event such as being widowed or a marital separation, it would be necessary to provide an individual with additional income. Viewing widowhood as an exogenous event, and so a kind of natural experiment, this number may be thought of as the 'value' of marriage. A different interpretation of this type of correlation is that happy people are more likely to stay married. It is clear that this hypothesis cannot easily be dismissed if only cross-section data are available. However, panel data on well- 
being suggest that similarly large effects are found when looking longitudinally at changes (thus differencing out person specific fixed effects). If high income goes with more happiness, and characteristics such as unemployment and being black go with less happiness, it is reasonable to wonder whether a monetary value could be put on some of the other things that are associated with disutility. Further calculation using the life satisfaction data in Appendix Table A suggests that to 'compensate' for unemployment compared with being a manual worker would take a rise in net income of approximately $€ 3,900$ per month, which is very large given the mean in the data of $€ 1,392$ and to 'compensate' for being married or living together would take $€ 1,770$ Euros compared to being single. ${ }^{9}$ Blanchflower and Oswald (2004) also found large effects for the US using the GSS data. These effects seem large and inconsistent with the claims of Kahneman et al (2004) that the size of the effects of circumstances on well-being are, 'surprisingly small'.

Table 8 examines data from the 2002 European Social Survey (ESS) across 20 EU countries plus Israel and Switzerland. Data are provided in columns 1-3 on happiness and life satisfaction. The rankings are very similar to those reported in Table 7 - France then the UK then Denmark at the top. The patterns in the data are similar to those identified above happiness and life satisfaction is higher for the most educated, for married people, the employed and the healthy. Happiness and life satisfaction are U-shaped in age. Table 9 uses data from a single Eurobarometer \#57.2 on life-satisfaction (5-step) also with and without health status dummies. There is a U-shape in age in every case. Once again in all six cases the rankings are France then the UK and Denmark highest.

\footnotetext{
${ }^{9}$ This is done simply by dividing the coefficient on unemployment by the coefficient on household income i.e. $.6847 / .0001715=3903$ Euros. The size of these effects is even higher using the happiness data i.e. 6420 Euros for unemployment .
} 
Identical rankings to this are found in Table 10 which uses over three quarters of a million observations from a long time series of Eurobarometers on life satisfaction (4-step). The rank ordering is France, UK and Denmark for the period 1975-2006 as well as for all subperiods. The rankings were also the same as this when thirty separate equations were run with the same controls in every year individually (results not reported). It is also apparent from Appendix Table B that the structure of (OLS) life satisfaction equations is similar across the main European countries. Interestingly, the patterns of the life satisfaction appear to be very similar to those in the happiness data in the United States.

Blanchflower and Oswald (2008b) found that psychological well-being is U-shaped through life. A difficulty with research on this issue is that there are likely to be omitted cohort effects (earlier generations may have been born in, say, particularly good or bad times). First, using data on 500,000 randomly sampled Americans and West Europeans, the paper designs a test that can control for cohort effects. Holding other factors constant, we showed that a typical individual's happiness reaches its minimum -- on both sides of the Atlantic and for both males and females -- in middle age. Second, evidence was provided for the existence of a similar Ushape through the life-course in East European, Latin American and Asian nations. Third, a Ushape in age is found in separate well-being regression equations in 72 developed and developing nations. Fourth, using measures that are closer to psychiatric scores, Blanchflower and Oswald (2008b) document a comparable well-being curve across the life cycle in two other data sets: (i) in GHQ-N6 mental health levels among a sample of 16,000 Europeans, and (ii) in reported 
depression and anxiety levels among 1 million U.K. citizens. ${ }^{10}$ Evidence of a U-shape in age is found in all life satisfaction and happiness equations reported in this paper. ${ }^{11}$

Easterlin (2006) argues that happiness in the US, as well as family satisfaction and job satisfaction in the US follow an inverse U-shape in age. ${ }^{12} 13$ His evidence was based on data from the General Social Surveys from 1973-1994. It is true in the raw data, or in specifications that do not include income or marital status as controls, that there is an inverse U-shape in the data in these three variables but only in the USA. ${ }^{14}$ However, once marital status alone is included the U-shape flips and the sign of the time trend reverses, as can be seen below in the two ordered logits with t-statistics in parentheses estimated on the GSS data from 1972-2006. ${ }^{15}$

$\begin{array}{lcc}\text { Age } & +.0152(5.18) & -.0276(8.92) \\ \text { Age }^{2} & -.00011(3.76) & .00031(10.21) \\ \text { Time }(1972=0) & -.0032(3.52) & .0044(4.79) \\ \text { Married } & & .9872(49.23) \\ \text { cut1 } & -1.6061 & -1.9501 \\ \text { cut2 } & 1.1330 & .9123 \\ \mathrm{~N} & 46,153 & 46,149 \\ \text { Pseudo } \mathrm{R}^{2} & .0011 & .0299\end{array}$

Easterlin (2007) only includes controls for gender, education and year of birth and its square, and I replicate his results with these variables using the longer time run of data from 1973-2006. I include controls for gender, schooling, race, region, birth decade, plus marital status and labor

${ }^{10}$ Clark (2007) finds a similar result in the UK using data from the BHPS even after controlling for cohort effects.

${ }^{11}$ See Tables 5-10 and 12.

12 However, Easterlin (2006) did find a U-shape in health and satisfaction with their financial situation .

${ }^{13}$ Analogously Mroczek and Spiro (2005) found that subjective well-being follows an inverted U-shape peaking at around retirement age.

${ }^{14}$ If an ordered logit is run with each of these five variables along with only age and its square there is an inverse Ushape for happiness, family satisfaction and job satisfaction (workers only). There is a U-shape for the family's financial situation while for the health variable only the age square term is significant and negative.

${ }^{15}$ Note in the data that the proportion married falls from $71.9 \%$ in 1972 to $48.1 \%$ in 2006 . 
market status in Table $11 .{ }^{16}$ In each case there is a U-shape in age after the inclusion of controls. ${ }^{17}$

I estimated fourteen separate OLS equations for the largest European countries using the 1972-2006 Eurobarometers; in each case the dependent variable was life satisfaction scored from 1-4 with only age and its square as controls. Below we report signs of the variables if significant at $1 \%$ on a two tailed test. If insignificant a zero is entered. In every country except Austria there is a significant U-shape in age. The coefficients, all of which were highly significant, were as follows

$\begin{array}{lllcc}\text { Austria } & \begin{array}{c}\text { Age } \\ \text { Age }^{2}\end{array} & \begin{array}{c}\text { Minimum } \\ \mathrm{n} / \mathrm{a}\end{array} & \mathrm{N} \\ \text { Belgium } & -.0035 & 0 & 69,309 \\ \text { Denmark } & -.00692 & .000055 & 63 & 61,840 \\ \text { Finland } & -.00331 & .000028 & 60 & 61,023 \\ \text { France } & -.01312 & .000117 & 56 & 19,646 \\ \text { Germany } & -.01943 & .000208 & 47 & 63,253 \\ \text { Greece } & -.00512 & .000056 & 46 & 92,815 \\ \text { Ireland } & -.01741 & .000127 & 68 & 49,863 \\ \text { Italy } & -.00766 & .000105 & 36 & 59,983 \\ \text { Netherlands } & -.00745 & .000054 & 69 & 63,587 \\ \text { Portugal } & -.00918 & .000084 & 55 & 61,699 \\ \text { Spain } & -.01572 & .000096 & 82 & 41,286 \\ \text { Sweden } & -.01510 & .000140 & 54 & 41,201 \\ \text { UK } & -.00768 & .000073 & 53 & 19,602 \\ & -.00619 & .000077 & 40 & 81,992\end{array}$

When controls are included - for education, gender, marital status, labor market status and time in Appendix Table 1 all of these countries had significant U-shapes in age. Table 12a uses 5-step happiness data for thirteen Asian countries for 2003 and 2004 drawn from the

\footnotetext{
${ }^{16}$ I use a slightly different health variable than the one used by Easterlin (2007). I used health whereas Easterlin used Sathealth, which was only available for a subset of years.

${ }^{17}$ Health satisfaction declines with age in the raw data which is consistent with the findings of Deaton (2007) who also found that health satisfaction declined with age.
} 
Asianbarometers. ${ }^{18}$ The variables work in the same way as for other countries; and there are Ushapes in age with minima of 46 from column 3 for the two years pooled. However, there is no U-shape in the raw data as was found in the USA. Analogously, simply adding marital status variables generates a significant U-shape. Well-being is U-shaped in age whether measured by life satisfaction, happiness or the U-index once controls are included and in many countries even in the raw data. Cambodians and South Koreans are the least satisfied while those from Brunei and Singapore the most satisfied.

Table $12 \mathrm{~b}$ uses data on 5-step life satisfaction for nine Asian and 9 European countries from the Asia/Europe Survey (ASES) of 2001. Happiness is U-shaped in age and rises with education. The unemployed are especially unhappy in Europe but are also unhappy in Asia. In both Asia and Europe native English speakers are especially happy - those with no understanding of English at all are less happy. Swedes are especially happy and Portugueses unhappy. There is a similar pattern to the Asian country dummies to those reported in Table 12a: Koreans are especially unhappy and Malaysians and Singaporeans notably happy.

\section{Econometric evidence on hypertension, unhappiness and pain}

The question then is whether the pattern of results we have seen using happiness and life satisfaction are repeated when we make use of self-reported data on unhappiness including high blood pressure, being under strain, being unable to sleep, being tired, under stress and in pain. It turns out that the results mostly go through. A modern literature has claimed that countries like Denmark, Ireland and the Netherlands are particularly happy while nations such as Germany, Italy and Portugal are less happy. Yet it is arguably implausible that words such as 'happiness' or

\footnotetext{
${ }^{18}$ The 5-step happiness scale is very unhappy; not too unhappy; neither; pretty happy and very happy. The raw means by country were; Brunei 4.45; Cambodia 3.34; China 3.73; Indonesia 3.71; Japan 3.70; Korea 3.37; Laos 3.66; Malaysia 3.93; Myanmar 3.71; Philippines 3.82; Singapore 3.99; Thailand 3.88 and Vietnam 3.87.
} 
'satisfaction' can be communicated unambiguously and in exactly the same way across countries, so it is not easy to know whether such cross-national well-being patterns are believable. Evidence on blood pressure across nations suggests that such happiness findings are credible. This is illustrated in Table 13 which uses data from two individual Eurobarometers \#56.1 for 2001 in columns 1-5 and a more recent one, \#64.4 for December 2005-January 2006. Column 1 of Table 13 reports an ordered logit estimating whether an individual has high blood pressure from Blanchflower and Oswald (2008a) who showed that self-reported high blood pressure across individuals and countries is negatively correlated with self-reported happiness. Denmark ranks lowest on blood pressure and France highest. More recently Mojon-Azzi and Sousa-Poza (2007) show that even with more objective measures of hypertension a negative relationship between high blood pressure problems and life satisfaction can be observed. They examined life satisfaction (scored in the normal way from 1-4, and self-reported blood pressure, including whether the respondent took blood pressure medication, for a sample aged 50+ from the Survey on Health, Ageing and Retirement in Europe. Their main results were as follows; note that the correlation with life satisfaction was higher with taking medication (correlation=.79) than with self-reported high blood pressure (correlation $=-.66$ ).

$$
\text { Satisfaction score } \% \text { high blood pressure } \% \text { taking blood pressure }
$$

$\begin{array}{llll}\text { Austria } & 3.25 & 30.9 & 31.3 \\ \text { Belgium } & 3.33 & 30.5 & 26.1 \\ \text { Denmark } & 3.65 & 28.6 & 26.4 \\ \text { France } & 3.02 & 27.9 & 30.8 \\ \text { Germany } & 3.19 & 35.4 & 34.9 \\ \text { Greece } & 3.23 & 33.0 & 32.6 \\ \text { Israel } & 3.04 & 41.4 & 41.8 \\ \text { Italy } & 3.00 & 36.1 & 35.9 \\ \text { Netherlands } & 3.56 & 24.8 & 24.2 \\ \text { Spain } & 3.30 & 34.3 & 32.4 \\ \text { Sweden } & 3.33 & 28.8 & 27.9 \\ \text { Switzerland } & 3.43 & 25.6 & 27.9\end{array}$


Happy countries seem to have fewer blood-pressure problems. This has two implications. First, it suggests that there may be a case to take seriously the subjective 'happiness' measurements made across the world: they follow a pattern like the (inverse of) high-blood-pressure estimates. Second, in constructing new kinds of economic and social policies in the future, where wellbeing rather than real income is likely to be a prime concern, there are grounds for economists to study people's blood pressure. The results on blood pressure validate the differences in happiness across nations in part because people can report high blood-pressure in a more objective way than they report levels of happiness;

The second column of Table 13, which is taken from Blanchflower and Oswald (2008a, column 4, Table 5), estimates an OLS where the dependent variable is a measure of psychological distress constructed (in the spirit of the well-known General Health Questionnaire score) by amalgamating answers to the questions:

Have you recently:

1. Lost much sleep over worry?

2. Felt constantly under strain?

3. Felt you could not overcome your difficulties?

4. Been feeling unhappy and depressed?

5. Been losing confidence in yourself?

6. Been thinking of yourself as a worthless person?

To the answers to each of these six, we assigned the integers $0,1,2,3$-- depending whether each was answered not at all, no more than usual, rather more than usual, much more than usual. The numerical answers were summed, and we term the result a 'GHQ-N6' measure, where $\mathrm{N}$ stands for 'negative'. The mental distress score denoted GHQ-N6, must for a person therefore lie between 0 and 18. Across Europe, the mean of the variable is 3.6 (standard deviation 3.7). These six are the 6 negative questions from the fuller General Health Questionnaire GHQ-12 measure of psychological distress. The data set does not provide data on the other six 'positive' 
questions. Thus our focus is upon negative affect. The rank ordering is the same once again France the most depressed, then the UK, and then Denmark the least depressed. Column 3 then estimates an ordered logit with the dependent variable whether an individual reports whether they feel 'unhappy or depressed'; column 4 models whether they 'had been feeling constantly under strain' and column 5 refers to whether they had 'lost much sleep over worry'. The rankings were once again in all cases France the most depressed and Denmark least depressed. Column 6 of Table 13 uses a different question from another Eurobarometer \#64.4 for 2005/6 - the respondent was asked whether during the preceding four weeks they had felt 'downhearted and depressed'. Rankings were the same - France then the UK and then Denmark.

Atlas and Skinner (2007) examined the prevalence of pain in the US population using the 2004 Health and Retirement Study (HRS) for approximately 18,000 people aged 50+. Among 50-59 year olds, rates of pain ranged from 19 percent for male college graduates to 55 percent among female respondents who did not finish high school. A variety of covariates in the HRS such as occupation, industry, and marital status attenuated but did not erase these gradients. Atlas and Skinner found differences across educational groups, with rates of people aged 50-59 troubled by pain ranging from 20 percent for men with a college education to 55 percent of women who did not finish high school. Data from Eurobarometer \#64.4 for 2006 allows us to examine this issue across 31 European countries $(n=28,000)$. Respondents were asked: 'During the past four weeks how much if at all, has pain interfered with your activities? Extremely, quite a lot, moderately, a little and not at all?'. The weighted percentage for the EU29 average reporting 'quite a bit' or 'extremely' was as follows, by gender

$\begin{array}{lcc} & \text { Men } & \text { Women } \\ \text { ALS }<=15 \text { years } & 17 & 24 \\ \text { ALS } 16-19 \text { years } & 9 & 12 \\ \text { ALS }>=20 \text { years } & 7 & 9\end{array}$


The data here are consistent with those reported by Atlas and Skinner for the US - pain declines with education. I find that pain rises with age in Europe for all levels of education, whereas Skinner and Atlas found some evidence of that for the more educated but the reverse, surprisingly, that pain fell with age from age 50 up for the least educated. Column 7 of Table 13 estimates an ordered logit and confirms that, ceteris paribus, pain declines with level of education and rises with age and is lower for men. Countries with the highest amount of pain were all from Eastern Europe (Poland; Slovakia; Latvia; Romania; Czech Republic; Lithuania; Slovenia; Croatia; Bulgaria and Estonia).who all have low rankings on happiness and life satisfaction equations (Tables 7 and 10). ${ }^{19}$ Countries with the least pain, in order, are Ireland and the UK. The French report higher levels of pain than either the British or the Danes. Alongside the evidence on hypertension the evidence from the incidence of pain does seem a further validation of the findings from the SWB data rather than the U-index. It is difficult to believe that data on pain and blood pressure are as susceptible to the K2S3 criticisms that the French are less emphatic when reporting their well-being. ${ }^{20}$

There seems very clear evidence then that the patterns in both happiness and unhappiness equations are remarkably stable across datasets, countries and however the question is asked. They also appear to be broadly consistent in other attitudinal questions relating to the state of the economy, government and even law and order. The evidence does seem to suggest dramatic stability in the cross country rankings. Table 14 examines happiness and life satisfaction data as

\footnotetext{
${ }^{19}$ I ran a happiness equation (how much of the time have you felt happy over the past four weeks - never, rarely, sometimes, most of the time, all the time?) with the same dataset and the rankings of these countries out of 31 was Poland (17); Slovakia (20); Latvia (30); Romania (24); Czech Republic (14); Lithuania (27); Slovenia (13); Croatia (23); Bulgaria (31) and Estonia (29). The overall correlation between the country coefficients from the pain and happiness equations was -.61.

${ }^{20}$ In ongoing work Andrew Oswald and I have also found that pulse rates are also highly correlated with (un)happiness scores. Indeed, the structure of a pulse equation is very similar to that of a GHQ score in terms of its determinants. This work is being conducted using data from the English National Health Surveys of 1998-2007.
} 
well as data on unhappiness from a recently available sweep of the European Social Survey of 2006/7. The broad structure of both the happiness and life satisfaction equations are as before U-shaped in age, higher for women, the more educated, the married, the healthy and the employed. We also estimate an equation relating to the respondent's standard of living. The structure of the unhappiness equations - here relating to depression, loneliness and anxiety have the inverse structure. The country rankings were as below - in all cases Denmark highest (lowest) and France lowest (highest) for happiness and unhappiness respectively.

1) Life satisfaction

2) Happiness

3) Standard of living

4) Depressed

5) Lonely

6) Anxious

$\begin{array}{ccc}\text { Denmark } & \text { France } & \text { Great Britain } \\ 1 & 14 & 9 \\ 1 & 10 & 7 \\ 1 & 11 & 7 \\ 18 & 11 & 12 \\ 19 & 6 & 12 \\ 17 & 8 & 12\end{array}$

I explored responses to a number of other attitudinal variables relating to the respondent's wellbeing over the preceding week whereas the other questions, as Krueger and Schkade (2007) suggest, "elicit a global evaluation of one's life". ${ }^{21}$ Ordered logits were again estimated with the same controls as in Table 14: once again they had a similar structure as above. For example, in all cases happiness was U-shaped in age and unhappiness followed an inverted U-shape. In four of the five 'happiness' questions, Denmark ranked higher than France while in four of the six 'unhappiness' questions Denmark also ranked lower than France. Countries below are ranked by coefficient size positive to negative.

\section{Happiness ranks}

You were happy?

You enjoyed life?

You had a lot of energy?
Denmark France Great Britain

$\begin{array}{rrr}10 & 4 & 5 \\ 4 & 2 & 5 \\ 11 & 7 & 17\end{array}$

\footnotetext{
${ }^{21}$ The question asked was as follows. Using this card, please tell me how much of the time during the past week. A) None or almost none of the time. B) Some of the time. D) Most of the time. D) All or almost all of the time?
} 
You felt calm and peaceful?

You felt really rested when you woke up in the morning?

$\begin{array}{rll}1 & 16 & 18 \\ 12 & 15 & 19\end{array}$

Unhappiness ranks

You felt that everything you did was an effort?

Your sleep was restless?

You felt sad?

$\begin{array}{rrr}7 & 13 & 10 \\ 9 & 7 & 2 \\ 17 & 13 & 12 \\ 11 & 19 & 6 \\ 8 & 6 & 3 \\ 17 & 13 & 5\end{array}$

You could not get going?

You felt tired?

You felt bored?

The rankings of countries when the questions relate to relatively short time periods such as a week are somewhat different from those obtained when questions covering the respondent's life more globally are examined. This seems more consistent with findings with the U-index that relate to even shorter time periods.

\section{The Macro-economics of Well-being}

I have increasingly become interested in the well-being data in the role as a macro policy maker. In the raw data happiness (and life satisfaction) is negatively correlated with unemployment (Figure 3) and inflation (Figure 4). It also appears that happiness is positively correlated with GDP growth (Figure 5 - taken from Leigh and Wolfers (2006)). When a nation is poor it appears that extra riches raise happiness. However, income growth in richer countries is not correlated with growth in happiness. This is the Easterlin hypothesis (Easterlin, 1974) and is illustrated in Figure 6, which uses data from the 1995/2000 World Values Survey; the slope of the function for western countries is approximately horizontal.

There is a small body of literature which uses SWB data across countries and through time to estimate a 'misery index'. Di Tella, McCulloch and Oswald $(2001,2003)$ and Di Tella, and MacCulloch (2007) use life satisfaction data to show that people are happier when both inflation and unemployment are low. They all find that unemployment depresses well-being more than does inflation. Di Tella and MacCulloch (2007) suggest that left-wing individuals care more 
about unemployment relative to inflation than right-wingers. Wolfers (2003) has also shown that greater macro volatility undermines wellbeing.

Table 15 uses aggregate life satisfaction data by country*year cell from the World Database of Happiness, with the dependent variable the score on a 4-step scale. Results are reported without a lagged dependent variable in columns 1 and 3 and with one added in columns 2 and 4, but this has little effect on the results. In columns 3 and 4, GDP per capita is added in US dollars but is always insignificant once controls for unemployment and inflation are included. The rank ordering of countries, once again is France, the UK, the USA with Denmark highest. Both unemployment and inflation lower happiness. A one percentage point increase in unemployment has a larger impact than a one percentage point increase in inflation in all four columns. If GDP per capita is included without controls for inflation or unemployment but with country and year dummies it enters positively and significantly. If an additional term is included where GDP is interacted with a poor country dummy the results were as follows with T-statistics in parentheses. ${ }^{22}$

$\begin{array}{llc} & \begin{array}{l}\text { Without a lagged } \\ \text { dependent variable }\end{array} & \begin{array}{c}\text { With a lagged } \\ \text { dependent variable }\end{array} \\ \mathrm{GDP}_{\mathrm{t}} & .000016(11.84) & .00000247(2.12) \\ \text { GDP poor country }_{\mathrm{t}} & .0000287(6.46) & .00000746(2.14)\end{array}$

Both terms are significant and positive but the slope for the richer countries is less steep than found for the poorer countries - there is diminishing marginal utility of income. This is the Easterlin effect. This does suggest that rising GDP per capita raises happiness less for the developed than for the developing countries which is consistent with the findings of Deaton (2008) who argues that "it is not true that there is some critical level of GDP per capita above

\footnotetext{
22 'Poor' is defined here as having 2004 GDP per capita of $<\$ 20,000$ which includes the Czech Republic $(\$ 6,263)$; Hungary $(\$ 5,626)$; Italy $(\$ 19,506)$; Mexico $(\$ 6,006)$; Poland $(\$ 5,032)$; Portugal $(\$ 11090)$; Slovakia $(\$ 4,483)$ and Spain $(\$ 15,403)$ with GDP per capita in \$US in parentheses.
} 
which income has no further effect on happiness" (2007, pp. 16-17). It is also consistent with the findings of Helliwell (2003, p. 345) who uses data from the first three sweeps of the WVS and finds that in a life satisfaction equation across countries "national average income also has diminishing returns, since the logarithm of average per capita income takes a positive coefficient, while the square takes a negative coefficient". This result is different from the findings of Easterlin $(1974,1995)$ that happiness does not increase for long time spans despite large increases in income. Consistent with this result is the fact that happiness levels for a number of EU countries have increased over time. Indeed, in the pooled Eurobarometers 1973-2006 microdata files if we simply regress life satisfaction in an OLS on a time trend only there is a significant upward trend in life satisfaction for ten countries - Denmark, the UK, France, Finland, Ireland, Luxembourg, the Netherlands, Spain, Sweden and Italy. There is a negative trend for Portugal, Germany and Belgium and no significant trend for Austria and Greece. ${ }^{23}$

Table 16 uses micro data on over 700,000 individuals from fifteen countries for which I have long time series of inflation data back to the 1950s (Austria; Belgium; Denmark; Finland; France; Germany; Greece; Ireland; Italy; Netherlands; Norway; Portugal; Spain; Sweden and the UK) drawn from the Eurobarometers from 1973-2006 and reported in Blanchflower (2007). As in Table 15 which uses macro data, controls are included for the unemployment rates and the inflation rate, but here standard errors are clustered at the country*year cell. Once again both macro variables enter negatively and the ranking is Denmark, UK and finally France the lowest. Column 2 adds the variable reflecting the average annual inflation experience of each individual in our sample given their age, country, and year the life satisfaction survey was conducted; this

${ }^{23}$ Data are available from 1973-2006 for Belgium, France, Denmark, Germany, Ireland, Italy, Luxembourg, Netherlands and the UK. For 1981-2006 for Greece, 1985-2006 for Portugal and Spain and from 1995-2006 for Austria, Finland and Sweden. 
term is insignificant. Column 3 substitutes the average annual experience term, for the highest annual inflation rate experienced by each individual over their adult life. This term is negatively signed and significant, and its inclusion has essentially no effect on either the coefficients on inflation or unemployment. An individual who has experienced high inflation in the past has lower happiness today, even holding constant today's inflation and unemployment rates. Unemployment appears to be more costly than inflation in terms of its impact on wellbeing. In Blanchflower (2007) I used these data to estimate a misery-index which measures the relative effect of a one percentage point increase in unemployment compared with a one percentage point increase in inflation. The estimates imply individuals weight the loss from unemployment 1.6 times more than the loss in well-being from inflation. ${ }^{24}$ Columns 4 and 5 of the table provide separate estimates for those under forty and those ages 40 and older. Interestingly, for the younger group the misery index is close to 1.4 , whereas for the older group it is approximately 2.1, while the size of the loss of happiness for the unemployed is similar. ${ }^{25}$ Interestingly, the highest inflation term, which is negative and significant in both cases, is much larger in size in the former case although its mean is much lower (20.2 and 116.2 respectively).

In Table 17 I explore the impact of the macro-economy on individual happiness and life satisfaction using self-reported views on unemployment, inflation and inequality using data from three recent Eurobarometers from 2006 and 2007. The results are very similar to those based on

\footnotetext{
${ }^{24}$ The misery-index is calculated in Blanchflower (2007) as the coefficient on the unemployment rate plus the loss for the unemployed themselves, divided by the coefficient on the inflation rate. The loss to the individual from being unemployed can be calculated from the coefficient on being 'unemployed' in a life-satisfaction micro regression, like the one reported in column 1 of Table 11, estimated with OLS to keep the units consistent - we get -.3657 . The entire well-being cost of a 1 percentage-point increase in the unemployment rate is therefore given by the sum of two components. Combining the two, we have $.0114+.0036=.0147$ as society's overall wellbeing cost of a one percentage point rise in the unemployment rate divided by .0094. The implication is that the wellbeing cost of a 1 percentage point increase in the unemployment rate equals the loss brought about by an extra $\mathbf{1 . 5 6}$ percentage points of inflation.

${ }^{25}$ Calculated as $(.0102+.0036) / .0109=1.27$ and $(.0128+.0039) / .0081=2.06$ respectively.
} 
using the macro data; we also have evidence that inequality lowers happiness. In the first column the results from estimating a series of ordered logits are reported with four-step happiness as the dependent variable. In addition to the standard controls of labor market and marital status, schooling, gender, age and country dummies plus a number of additional controls not available in other data files. First, if the respondent is a member of a minority group as well as if they are not part of the majority but do not associate themselves with a particular group: both enter significantly and negative with the effect three times larger for minorities. Second, controls are included to distinguish whether they owned their house outright or with a mortgage, which both enter significantly positive. Third, I include a control identifying whether the respondent belonged to a religious organization which also is significant and positive. Fourth, following Di Tella and MacCulloch (2005) and Alesina et al (2004) I include controls for an individual's political views on a scale from 1 (Left) to 10 (Right) and show that right wingers are happiest. Finally, I include three variables based on an individual's response to a question asking what topics "worry you the most"? I include responses relating to unemployment, inequality and the cost of living (inflation); multiple responses are possible. Unemployment and inflation lowers happiness as does inequality following Alesina et al (2004) and Blanchflower and Oswald (2004). Column 2 uses data from Eurobarometer \#66.1 which uses a four-step life satisfaction dependent variable confirms that both unemployment and inflation lowers pay - information on inequality is available in that survey. ${ }^{26}$

Column 3 also uses a four-step data on life satisfaction from a 2007 Eurobarometer \#67.2 with slightly different attitudinal questions. Once again the unemployed have lower life satisfaction, $\backslash$; happiess is U-shaped in age, higher for the married and for those who own their

\footnotetext{
${ }^{26}$ Similar results are also found using Eurobarometer \#64.1 but which does not contain details of home ownership.
} 
own house and especially high in Denmark and low in Bulgaria. The main difference in column 3 is that now the macro controls relate to whether the respondent believes that inflation is lower than, equal to or higher than it was a year earlier. Once again happiness is lower when the respondent reports that inflation or unemployment is higher. Unemployment, inflation and inequality all appear to lower happiness and life satisfaction.

\section{Predictions and expectations}

I recall John Abowd saying to me at a very early seminar given at the NBER, that the crucial test for the happiness data is whether or not it has any predictive power. Little work has so far been done on this question, but in some recent work I found that life satisfaction levels in Eastern European countries is a good predictor of migration flows to the UK. On May $1^{\text {st }} 2004$ to the so called A8 accession countries (the Czech Republic; Estonia; Hungary; Latvia; Lithuania; Poland; Slovakia; and Slovenia) joined the European Union. ${ }^{27}$ Citizens from the A8 nations obtained free movement and the right to work in the UK, Ireland and Sweden from May $1^{\text {st }} 2004 .^{28}$ Gilpin et al (2006) examined data for the UK drawn from the Worker Registration Scheme, which registers the A8 workers, and computed the number of WRS registrations as a percentage of the home country population and show it is correlated with GDP and unemployment. Gilpin et al. found that countries with the lowest GDP per head, such as Lithuania (2,500 Euros) are more likely to be registered on the UK WRS than those from countries with higher GDP, such as Slovenia (11,400 Euros). ${ }^{29}$ The propensity to migrate is even

\footnotetext{
${ }^{27}$ In addition Malta and (South) Cyprus also joined the EU at that date. Bulgaria and Romania joined the EU on January $1^{\text {st }} 2007$.

${ }^{28}$ Finland, Greece, Portugal and Spain opened their labour markets to these workers on May $1^{\text {st }} 2006$, while Italy followed in late July 2006. Five other countries (Belgium, Denmark, France, the Netherlands and Luxembourg) alleviated restrictions in 2006 (Zaiceva, 2006).

${ }^{29}$ Expressed as Euros per inhabitant at 1995 exchange rates and prices.
} 
more highly correlated with life satisfaction than it is with GDP per capita (Blanchflower and Shadforth, 2007).

Of interest is whether life satisfaction or happiness is correlated with people's expectations of the economic situation. It turns out that they are. Respondents in thirteen separate Eurobarometers for the period 1995-2006 were asked the following questions.

"What are your expectations for the next twelve months: will the next twelve months be better; worse or the same when it comes to a) your life in general b) the economic situation in (our country) c) the financial situation of your household d) the employment situation in (our country) d) your personal job situation?".

Data are available on 15 countries for all twelve years (Austria, Belgium, Denmark, Finland, France, Germany, Greece, Ireland, Italy, Luxembourg, the Netherlands, Portugal, Spain, Sweden and the UK). Data for the fifteen Accession and Candidate countries (Republic of Cyprus; Czech Republic; Estonia; Hungary; Latvia; Lithuania; Malta; Poland; Slovakia; Slovenia; Bulgaria; Romania; Turkey; Croatia and Cyprus (Turkish Cypriot Community) are present for only 2004-2006. In eight separate surveys respondents were also asked about their expectations for themselves ten years hence - "In the course of the next five years, do you expect your personal situation to improve, to stay about the same or get worse?". Life satisfaction is further reported in a subset of these surveys. We examine three of these responses here.

Table 18 reports results of estimating ordered logits for parts b), d) and a) as well as for life five years ahead. The dependent variable is coded as one if the response was 'worse', 2 if 'the same ' and 3 if 'better', so positive coefficients should be interpreted once again as suggesting the variable raises the probability of life improving. Column 1 and 2 of Table 18 relates to the individual's views on the economic situation, columns 3 and 4 to the employment situation and columns 5 and 6 to their life over the following twelve months and columns 7 and eight for life 
over the following five years. In each case separate results are provided with and without three life satisfaction controls derived from the standard 4 category life satisfaction variable. Happiness enters significantly and positively in each of these equations. This is similar to findings by Guven (2007) who found using data from the Netherlands and Germany that happiness increases savings, decreases expenditures, and the marginal propensity to consume is lower for the happy people. Happy people, Guven also found, are a) more risk averse in financial decisions b) expect to live longer c) are more concerned about the future than the present d) expect lower prices in the future e) are less likely to smoke and f) do not desire to move within a country. ${ }^{30}$

There is a common pattern in the control variables across all eight specifications. Optimism 1) rises with educational attainment 2) is U-shaped in age 3) is lower for married and widowed, the unemployed and is higher the greater the level of current happiness. The country ranking in relation to people's views on the economic and employment situations is once again France, UK and then Denmark. The British, though are especially optimistic that their life will improve and the Danes now less optimistic than the French. Happier people, it turns out, are less pessimistic about the state of the economy as well, unsurprisingly, about how their life will proceed. These country rankings are consistent with the evidence from the ESS 2002 reported in Table 8 above respectively, where the respondents report on their current views on the economy, government and democracy.

\footnotetext{
${ }^{30}$ Guven (2007) examined data on prices only for the Netherlands using data from the Dutch National Bank (DNB) Household Survey which is a panel of about 4500 individuals from 1993 to 2006. Data on price expectations are of particular interest to macro-policy makers. Guven found that happier people expect lower prices than unhappy people for the next year and also in five years time. Questions asked were 1) "Do you expect prices in general to rise, to remain the same, or to go down, in the next 12 months? $1=$ go down $2=$ remain the same $3=$ rise" 2 ) "By what percentage do you expect prices in total to have risen after 5 years?"
} 
Interestingly, respondents seem more optimistic about their own lives than they are about the economy or the employment situation in their country. For example, in the UK respondents are twice as likely to report that they think their own situation will improve, than think that either the economic situation or the employment situation of the country will improve. Moreover, the trend in the former is up, while the trend in the latter is down. The proportion of UK respondents saying that the situation in 12 months will be 'better' for the economic and employment situations and their life in general over the next twelve months is set out in Table 19. Annual percentage point ( $\mathrm{pp}$ ) changes in the unemployment and inflation rates are also shown. There is some evidence that respondents' expectations about the wider economic and employment situation in the Eurobarometers are well correlated with actual $(\mathrm{t}+1)$ macro outturns as can be seen below.

\begin{tabular}{|l|c|c|}
\multicolumn{2}{c}{} & \multicolumn{2}{c}{ Correlation matrix: } & $\begin{array}{c}\text { Annual pp changes } \\
\text { at time } t+1 \text { in }\end{array}$ \\
\hline Economic situation & Unemployment rate & Inflation \\
\hline Employment situation & -0.70 & -0.48 \\
\hline
\end{tabular}

Figure 7a plots the proportion of respondents in the Eurobarometers who say they expect the economic situation in the next twelve months in the UK to 'improve' (inverted) against changes in both the unemployment rate and the inflation rate. The responses to how the economic situation is expected to develop is also highly correlated with other surveys of economic confidence, such as the GfK and MORI measures of general economic confidence for the coming twelve months which use the same questions. The correlations are .73 and .85 respectively as shown in Figure $7 \mathrm{~b}$. Macro-economic variables appear to impact individual's expectations about their own lives and what they expect to happen to the economy as a whole, as does their current levels of happiness.

\section{Conclusions}


There are broadly consistent patterns in the SWB micro-data no matter what data file is used, no matter which country - perhaps excluding the poorest countries with low life expectancy. Results using data on well-being seem very similar to the results obtained from NTA - and potentially more stable as sample sizes are often large. Happiness appears to be a) Ushaped in age, b) higher for the most educated c) the higher paid, d) non-minorities e) the employed and f) for married people. Analogous results are found using self-reported unhappiness data. However, when such questions are asked in relation to the week prior to interview the country rankings are quite different and seem more consistent with findings with the U-index that relate to fifteen minute intervals.

Responses on blood pressure and pain appear to validate the happiness and life satisfaction data as they are likely less subject to any cultural and language differences which might arise, for example, if the French are less emphatic when reporting their well-being. Happy people and happy countries seem to have fewer blood-pressure and pain problems.

There are long consistent time runs of data available for macro-economic analysis dating back to the early 1970s. Well-being across nations is correlated with the unemployment rate, the current inflation rate and the highest inflation rate in a person's adult life as well as GDP growth rates especially in poorer countries. Happiness and life satisfaction data help to forecast including migration flows. Happy people are particularly optimistic about the prospects for the economy.

There are a number of SWB measures that can and already are being used in one form or another as an NHI. These seem to correlate strongly with other macro measures including the unemployment rate, the inflation rate, and even the suicide rate. The simplest and most widely available SWB measure is apparently the 4-step life satisfaction index which is already available 
in similar form in ongoing annual surveys for all EU countries collected by the EU Commission as well as in most Latin American countries. The fact that so much harmonized cross-country data are already available of this type is the singular attraction for this one measure. The one country where suitable data are unavailable is the United States, although 3-step happiness data have been available for many years in the General Social Surveys, which is quite small in size and now only collected bi-annually. ${ }^{31}$ I recommend that a 4-step life satisfaction plus a 3-step happiness question as soon as possible are included at regular intervals in one or more large national surveys in the US such as the Current Population Survey. The CPS is an obvious place to include it as it could be asked on more than one occasion to the same individual perhaps in the first and last rotation groups which would permit panel data analysis to be done over time for the same individuals. Such work has been possible in the UK using the BHPS and in Germany using the GSOEP but not to my knowledge in the USA. This needs to change.

Work on NTA appears to be an important complement to this work, but the 4-step life satisfaction NHI in my view should be its starting point. Obviously nations have different languages and cultures, and in principle this may cause biases in happiness surveys. K2S3 have identified that there appears to be a bias when comparing results from France with those from the US. They found that, on average, the French spent their days in a more positive mood and more of their time engaged in activities that tend to yield more pleasure than do Americans. The Americans seem to be more emphatic when reporting their well-being. Despite this, there are considerable similarities between the findings from the U-index and those from happiness and life satisfaction data. We are all trying to get utility proxy data for the $\mathrm{u}$ in the conventional utility function $\mathrm{u}(\mathrm{y})$, and in principle this is complementary to normal economics, not a rival to

\footnotetext{
${ }^{31}$ The World Database of Happiness does report data on 4-step life satisfaction (see Table 1) for the USA drawn from a number of small Gallup polls for the years 1991, 1997 and 2002-2004.
} 
it. 'Happiness data' no doubt have weaknesses but it seems unlikely they contain no useful information. A standard equation structure has now been replicated hundreds of times in a large number of nations, so we need to get to the bottom of it. Plus income comes in positive and concave; inflation and unemployment hurt; etc; and all this seems to make sense to economists. There are thus interesting regularities in wellbeing data. Whatever they mean, and whatever criticisms one might have of such data, it seems worth economists and others attempting to understand why these patterns exist. It is good scientifically if rather different subjective wellbeing measures give similar equation structures. They seem to.

A big question going forward is how to incorporate the findings from national time use with those from the subjective well-being literature. Of interest will be whether there are differences, for example, between countries who speak the same language such as the UK, Australia, Canada and New Zealand. Are there significant differences between the results obtained from NTA and SWB in other countries besides the US and France? If happiness is Ushaped in age, to what extent is the time use of the young different from that of the old? What is it that makes people unhappy in middle-age? Nations have different languages and cultures, and in principle that may cause biases, perhaps large ones, in happiness surveys. At this point in research on subjective well-being, the size of any bias is not known, and there is no accepted way to correct the data, but progress is being made. NTA and SWB appear to be complements rather than substitutes. There is still much work to be done. 


\section{References}

Alesina, A, R., Di Tella and R.J. MacCulloch (2004), 'Inequality and happiness: are Europeans and Americans different?', Journal of Public Economics, 88, pp. 2009-2042.

Atlas, S. and J. Skinner (2007), 'Education and the prevalence of pain', paper presented at the NBER Conference on Aging, Carefree, AZ, December.

Blanchflower, D.G. (2001), 'Unemployment, well-being and wage curves in Eastern and Central Europe', Journal of Japanese and International Economies, 15(4), pp. 364-402.

Blanchflower, D.G. (2007), 'Is unemployment more costly than inflation?', NBER Working Paper \#13505.

Blanchflower, D.G., and A.J. Oswald (2000), 'The rising well-being of the young', in Youth Employment and Joblessness in Advanced Countries, edited by D.G. Blanchflower and R.B. Freeman, Chicago: NBER and University of Chicago Press, Chicago.

Blanchflower, D.G., and A.J. Oswald (2004a), 'Well-being over time in Britain and the USA. Journal of Public Economics, 88, pp. 1359-1386.

Blanchflower, D.G., and A.J. Oswald (2004b), 'Money, sex and happiness', $\underline{\text { Scandinavian Journal }}$ of Economics, 106(3), pp. 393-415.

Blanchflower, D.G. and A.J. Oswald (2005), 'Happiness and the Human Development Index: the paradox of Australia', The Australian Economic Review, 38(3), September 2005, pp. 307$318(12)$.

Blanchflower, D.G. and A.J. Oswald (2006), 'On Leigh-Wolfers and well-being in Australia', The Australian Economic Review, 39(2), pp.185-186.

Blanchflower, D.G., and A.J. Oswald (2008a), 'Hypertension and happiness across nation', Journal of Health Economics, 27(2), pp. 218-233.

Blanchflower, D.G., and A.J. Oswald (2008b), 'Is Well-being U-shaped over the life cycle?', Social Science and Medicine, 66(6), pp. 1733-1749 .

Blanchflower, D.G. and C. Shadforth (2007), 'Fear, unemployment and migration', Economic Journal, forthcoming.

Carroll, N. (2007), 'Unemployment and psychological well-being', The Economic Record, 83(262), September, pp. 287-302

Clark, A.E. (2007), 'Born to be mild? Cohort effects don't (fully) explain why well-being is Ushaped in age', IZA DP \#3170. 
Clark, A.E. (2005), 'Your money or your life: changing job quality in OECD Countries', British Journal of Industrial Relations, 43, pp. 377-400.

Clark, A.E., P. Frijters and M. Shields (2007), 'Relative income, happiness and utility: an explanation for the Easterlin paradox and other puzzles', Journal of Economic Literature, (forthcoming).

Clark, A.E., and A.J. Oswald (1994), 'Unhappiness and unemployment', Economic Journal, 104, pp. 648-659.

Deaton, A. (2008), 'Income, aging, health and wellbeing around the world: evidence from the Gallup World Poll', Journal of Economic Perspectives, Spring, 22(2), pp. 53-72..

Di Tella R. and R.J. MacCulloch (2005), 'Partisan social happiness', Review of Economic Studies, 72, pp. 367-393.

Di Tella R. and R.J. MacCulloch (2006), 'Some uses of happiness data in economics', Journal of Economic Perspectives, 20(1), Winter, pp. 25-46.

Di Tella R. and R.J. MacCulloch (2007), 'Happiness, contentment and other emotions for central banks', NBER Working Paper \#13622.

Di Tella, R., MacCulloch, R. and J.P. Haisken-DeNew (2005), 'Happiness adaptation to income and to status in an individual panel', Harvard Business School Working Paper.

Di Tella, R., MacCulloch, R.J., and A.J. Oswald (2001), 'Preferences over inflation and unemployment: evidence from surveys of happiness', American Economic Review, 91, pp. 335341.

Di Tella, R., MacCulloch, R.J., and A.J. Oswald (2003), 'The macroeconomics of happiness', Review of Economics and Statistics, 85(4), pp. 809-827.

Easterlin, R. (1974), 'Does economic growth improve the human lot? Some empirical evidence', in David, P.A., Reder, M.W. (Eds.), Nations and households in economic growth, essays in honor of Moses Abramowitz, Academic Press, New York.

Easterlin, R. (1995), 'Will raising the incomes of all increase the happiness of all?', Journal of Economic Behavior and Organization, 27, pp.35-48.

Easterlin R. A. (2006), 'Life cycle happiness and its sources. Intersections of psychology, economics, and demography', Journal of Economic Psychology, 27, pp. 463-482

Easterlin R. A. and Anke C. Zimmermann (2008), 'Life satisfaction and economic conditions in East and West Germany pre- and post-Unification', Journal of Economic Behavior and Organisation, forthcoming. 
Ekman, P., R. Davidson and W. Friesen (1990), 'The Duchenne smile: emotional expression and brain physiology II', Journal of Personality and Social Psychology, 58(2), pp. 342-53.

Ekman, P., W. Friesen and M. O’Sullivan (1988), 'Smiles when lying', Journal of Personality and Social Psychology. 54(3), pp. 414-20.

Ferrer-i-Carbonell, A. (2005), 'Income and well-being: an empirical analysis of the comparison income effect', Journal of Public Economics, 89, pp. 997-1019.

Frey, B. S. and A. Stutzer (2002a), Happiness and economics, Princeton and Oxford: Princeton University Press.

Frey B.S. and A. Stutzer (2002b), 'What can economists learn from happiness research?', Journal of Economic Literature, 40(2), June, pp. 402-435.

Frey, B. S. and A. Stutzer (2005), 'Happiness research: state and prospects', Review of Social Economy, vol. LXII, No. 2, June, pp. 207-228.

Frijters, P., Haisken-DeNew, J. and Shields, M. (2004). 'Money does matter! Evidence from increasing real incomes and life satisfaction in East Germany following reunification', American Economic Review, 94, 730-740.

Gerdtham, U, and M. Johannesson (2001), 'The relationship between happiness, health, and socio-economic factors: results based on Swedish microdata', Journal of SocioEconomics, Volume 30, Issue 6, November-December, Pages 553-557.

Gilpin, N., M. Henty, S. Lemos, J. Portes and C. Bullen (2006), 'The impact of free movement of workers from Central and Eastern Europe on the UK labour market', Department of Work and Pensions, Working paper \#29.

Graham C. (2005). 'Insights on development from the economics of happiness', World Bank Research Observer, 20, pp. 201-231.

Guven, C. (2007), 'Reversing the question. Does happiness affect individual economic behavior? Evidence from surveys from Netherlands and Germany', Ph.D thesis, University of Houston. October.

Helliwell J. (2003), 'How's life? Combining individual and national variables to explain subjective well-being', Economic Modelling, 20(2), pp. 331-360.

Hinks, T., and C. Gruen (2007), 'What is the structure of South African happiness equations Evidence from quality of life surveys', Social Indicators Research, 82(2), pp. 311-336, June.

Kahneman, D. and A.B. Krueger (2006), 'Developments in the measurement of subjective wellbeing', Journal of Economic Perspectives, 20(1), Winter, pp. 3-24. 
Kahneman, D. A.B. Krueger, D. Schkade, N. Schwarz and A. Stone (2004a), 'Toward National Well-Being accounts', American Economic Review Papers and Proceedings, May, pp, 429-434.

Kahneman, D. A.B. Krueger, D. Schkade, N. Schwarz and A. Stone (2004b), 'A survey method for characterizing daily life experience: the Day Reconstruction Method (DRM)', Science, December $3^{\text {rd }}$, pp. 1776-1780.

Kimball, M., H. Levy, F. Ohtake and Y. Tsutsui (2006), 'Unhappiness after Hurricane Katrina', NBER Working Paper \#12062.

Kingdon, G.G. and J. Knight (2007), 'Community, comparisons and subjective well-being in a divided society', Journal of Economic Behavior and Organization, 64, pp. 69-90.

Koivuma, H.H., R. Honkanen, H. Viinamaeki, K. Heikkalae, J. Kaprio and M. Koskenvuo (2001), 'Life satisfaction and suicide; a 20-year follow-up study', American Journal of Psychiatry, 1589(3), pp. 433-439.

Krueger, A.B., D. Kahneman, D. Schkade, N. Schwarz and A.A. Stone (2007), 'National time accounting: the currency of life', Working Paper, November.

Krueger, A.B. and D. A. Schkade (2007), 'The reliability of subjective well-being measures', working paper \#516, Industrial Relations Section, Princeton University, January.

Leigh, A. and Wolfers, J. (2006), 'Happiness and the Human Development Index: Australia is not a paradox', Australian Economic Review, 39(2), pp. 176-184.

Lelkes, O. (2006), 'Life-cycle happiness'. European Centre, mimeo.

Luttmer, E. (2005), 'Neighbors as negatives; relative earnings and well-being', Quarterly Journal of Economics, August, 120(3), pp. 963-1002.

Mojon-Azzi, S. and A. Sousa-Poza (2007), 'Hypertension and life satisfaction: an analysis using data from the Survey of Health, Ageing and Retirement in Europe (SHARE)', Working paper, University of Hohenheim-Stuttgart, Germany.

Mroczek, D.K and A. Spiro (2005), 'Change in life satisfaction during adulthood: Findings from the Veterans Affairs Normative Aging study', Journal of Personality and Social Psychology, 88, pp. 189-202.

Oswald, A. J. (1997), 'Happiness and economic performance', Economic Journal, 107, pp. 18151831.

Powdthavee N. (2005), 'Unhappiness and crime: Evidence from South Africa', Economica, 72, pp. 531-547. 
Powdthavee N. (2007), 'Are there geographical variations in the psychological cost of unemployment in South Africa?', Social Indicators Research, 80(3), pp. 629-652, February.

Propper C., Jones K., Bolster A., Burgess S., Johnston R. and R. Sarker (2005), 'Local neighbourhood and mental health: Evidence from the UK', Social Science and Medicine, 61, 2065-2083.

Sanfey, P. and U. Teksoz (2007), 'Does transition make you happy?', Economics of Transition, 15(4), pp. 707-731

Senik, C. (2004), 'When information dominates comparison: a panel data analysis using Russian subjective data', Journal of Public Economics, 88, pp. 2099-2123.

Shields M.A. and S. Wheatley Price (2005), 'Exploring the economic and social determinants of psychological well-being and perceived social support in England', Journal of the Royal Statistical Society (Series A), 168, pp. 513-537.

Stevenson, B. and J. Wolfers (2007), 'The paradox of declining female happiness', working paper.

Theodossiou, I. (1998), 'The effects of low-pay and unemployment on psychological well-being: A logistic regression approach', Journal of Health Economics, 17, pp. 85-104.

Uppal, S. (2006), 'Impact of the timing and severity of disability on the subjective well-being of individuals with disabilities', Social Science and Medicine, 63, pp. 525-539.

Van Praag, B. and Ferrer-i-Carbonell, A. (2004), Happiness quantified. Oxford: Oxford University Press.

Veenhoven, R. (2000), 'Freedom and happiness: A comparative study in 44 nations in the early 1990s', in Diener, E. and Suh, E. (eds), Culture and Subjective Well-being, Cambridge, MA: MIT Press, pp. 257-288.

Winkelmann, L., and R. Winkelmann (1998), 'Why are the unemployed so unhappy? Evidence from panel data', Economica, 65, pp. 1-15.

Wolfers, J. (2003), 'Is business cycle volatility costly? Evidence from surveys of subjective wellbeing', International Finance, 6(1), pp. 1-26.

Zaiceva, A. (2006), 'Reconciling the estimates of potential migration into the enlarged European Union', IZA Bonn, Discussion Paper No. 2519.

Zimmermann, A.C. and R.A. Easterlin (2006), 'Happily ever after? Cohabitation, marriage, divorce, and happiness in Germany', Population and Development Review, 32(3), pp. 511- 528, September. 
Table 1. Four-step Life satisfaction in Europe, USA, Japan and Latin America

\begin{tabular}{|c|c|c|c|c|c|c|}
\hline & 2001 & 2002 & 2003 & 2004 & 2005 & 2006 \\
\hline \multicolumn{7}{|c|}{ 1) Western countries } \\
\hline Austria & 3.18 & 3.13 & 3.08 & 3.05 & 3.04 & 3.08 \\
\hline Belgium & 3.06 & 2.96 & 3.04 & 3.18 & 3.16 & 3.19 \\
\hline Denmark & 3.60 & 3.61 & 3.57 & 3.59 & 3.62 & 3.61 \\
\hline Finland & 3.11 & 3.14 & 3.15 & 3.29 & 3.26 & 3.23 \\
\hline France & 2.94 & 2.88 & 2.85 & 2.95 & 2.96 & 3.00 \\
\hline Germany & 2.94 & 2.86 & 2.75 & 2.96 & 2.93 & 2.87 \\
\hline Greece & 2.66 & 2.66 & 2.66 & 2.73 & 2.66 & 2.67 \\
\hline Ireland & 3.26 & 3.18 & 3.15 & 3.32 & 3.29 & 3.28 \\
\hline Italy & 2.93 & 2.95 & 2.86 & 2.86 & 2.83 & 2.85 \\
\hline Japan & 2.71 & 2.61 & 2.59 & 2.74 & 2.58 & $\mathrm{n} / \mathrm{a}$ \\
\hline Luxembourg & 3.31 & 3.30 & 3.25 & 3.44 & 3.42 & 3.39 \\
\hline Netherlands & 3.42 & 3.31 & 3.28 & 3.33 & 3.41 & 3.36 \\
\hline Portugal & 2.71 & 2.63 & 2.49 & 2.49 & 2.48 & 2.44 \\
\hline Spain & 3.07 & 3.02 & 3.01 & 3.13 & 3.03 & 3.08 \\
\hline Sweden & 3.35 & 3.32 & 3.28 & 3.40 & 3.42 & 3.39 \\
\hline UK & 3.21 & 3.18 & 3.17 & 3.23 & 3.20 & 3.19 \\
\hline USA & 3.35 & 3.33 & 3.37 & 3.42 & $\mathrm{n} / \mathrm{a}$ & $\mathrm{n} / \mathrm{a}$ \\
\hline \multicolumn{7}{|c|}{ 2) East Europe + Turkey } \\
\hline Bulgaria & 2.08 & 2.04 & 2.05 & 2.06 & 2.04 & 1.99 \\
\hline Czech Republic & 2.84 & 2.84 & 2.73 & 2.82 & 2.93 & 2.92 \\
\hline Estonia & 2.44 & 2.52 & 2.48 & 2.74 & 2.72 & 2.74 \\
\hline Hungary & 2.54 & 2.63 & 2.53 & 2.44 & 2.53 & 2.50 \\
\hline Latvia & 2.54 & 2.47 & 2.54 & 2.52 & 2.62 & 2.62 \\
\hline Lithuania & 2.29 & 2.46 & 2.52 & 2.55 & 2.56 & 2.62 \\
\hline Poland & 2.65 & 2.71 & 2.67 & 2.81 & 2.77 & 2.80 \\
\hline Romania & 2.12 & 2.20 & 2.10 & 2.32 & 2.35 & 2.33 \\
\hline Slovakia & 2.48 & 2.54 & 2.47 & 2.59 & 2.64 & 2.70 \\
\hline Slovenia & 3.04 & 3.03 & 3.04 & 3.17 & 3.10 & 3.09 \\
\hline Turkey & 2.26 & 2.43 & 2.71 & 2.87 & 2.90 & 2.84 \\
\hline \multicolumn{7}{|c|}{ 3) Latin America } \\
\hline & 1997 & 2000 & 2001 & 2003 & 2004 & 2005 \\
\hline Argentina & 2.14 & 2.21 & 2.82 & 2.91 & 2.92 & 2.94 \\
\hline Bolivia & 1.97 & 1.89 & 2.54 & 2.77 & 2.42 & 2.57 \\
\hline Brazil & 2.34 & 2.61 & 2.71 & 2.71 & 2.67 & 2.73 \\
\hline Colombia & 2.50 & 2.40 & 3.06 & 3.16 & 3.14 & 3.17 \\
\hline Costa Rica & 2.82 & 2.65 & 3.34 & 3.46 & 3.29 & 3.34 \\
\hline Chile & 2.32 & 2.84 & 2.82 & 2.92 & 2.80 & 2.85 \\
\hline Ecuador & 2.06 & 1.86 & 2.74 & 3.03 & 2.48 & 2.68 \\
\hline El Salvador & 2.49 & 2.34 & 2.90 & 3.34 & 2.88 & 2.90 \\
\hline Guatemala & 2.40 & 2.64 & 3.01 & 3.15 & 3.03 & 3.13 \\
\hline Honduras & 2.41 & 2.62 & 3.28 & 3.21 & 3.17 & 2.98 \\
\hline Mexico & 2.61 & 2.71 & 2.95 & 3.13 & 2.96 & 3.06 \\
\hline Nicaragua & 2.67 & 2.16 & 2.96 & 3.18 & 2.77 & 2.94 \\
\hline Panama & 2.38 & 2.78 & 2.64 & 3.17 & 3.13 & 3.21 \\
\hline Paraguay & 2.16 & 2.14 & 2.93 & 3.26 & 2.84 & 2.95 \\
\hline Peru & 1.70 & 1.72 & 2.48 & 2.74 & 2.49 & 2.50 \\
\hline Uruguay & 2.40 & 2.36 & 2.91 & 2.88 & 2.73 & 2.90 \\
\hline Venezuela & 2.45 & 2.82 & 3.26 & 3.36 & 3.26 & 3.45 \\
\hline
\end{tabular}

Source: Blanchflower and Shadforth (2007) plus Eurobarometers and Latinobarometers and World Database of Happiness. 
Table 2. U-Index, happiness and life satisfaction for various demographic groups

\begin{tabular}{|c|c|c|c|c|}
\hline & U-index & GSS & EB & LB \\
\hline \multicolumn{5}{|l|}{ Sex } \\
\hline Men & $17.6 \%$ & 30.9 & 27.0 & 30.5 \\
\hline Women & 19.6 & 31.3 & 26.8 & 30.1 \\
\hline \multicolumn{5}{|l|}{ Race/Ethnicity } \\
\hline White & 17.5 & 32.7 & & \\
\hline Black & 23.8 & 26.6 & & \\
\hline Hispanic & 21.9 & 24.8 & & \\
\hline \multicolumn{5}{|l|}{ Household Income } \\
\hline$<\$ 30,000$ & 22.5 & 31.8 & & \\
\hline$\$ 30,000-\$ 50,000$ & 18.6 & 23.6 & & \\
\hline$\$ 50,000-\$ 100,000(\$ 110 \mathrm{k})$ & 18.6 & 38.2 & & \\
\hline$>\$ 100,000$ & 15.7 & 46.8 & & \\
\hline \multicolumn{5}{|l|}{ Education } \\
\hline$<$ High School $/<16$ years & 20.5 & 28.9 & 19.3 & 28.0 \\
\hline High School/16-19 years & 21.3 & 31.2 & 25.1 & 31.6 \\
\hline Some College $/ 20+$ years & 19.6 & 31.7 & 34.8 & 32.4 \\
\hline College/still studying & 15.6 & 37.2 & 32.5 & \\
\hline Masters & 16.6 & 36.6 & & \\
\hline Doctorate & 11.3 & 36.4 & & \\
\hline \multicolumn{5}{|l|}{ Men } \\
\hline $15-24$ & 18.8 & 23.4 & 28.0 & 34.1 \\
\hline $25-44$ & 17.1 & 29.2 & 25.7 & 30.8 \\
\hline $45-64$ & 18.7 & 33.0 & 25.9 & 27.6 \\
\hline $65+$ & 15.6 & 39.8 & 30.5 & 28.0 \\
\hline Married & 17.4 & 39.0 & 29.3 & 33.6 \\
\hline Divorced/Separated & 24.3 & 17.5 & 18.6 & 27.1 \\
\hline Widowed & 20.2 & 22.1 & 21.6 & \\
\hline Never Married & 16.9 & 20.3 & 23.3 & 29.1 \\
\hline \multicolumn{5}{|l|}{ Women } \\
\hline $15-24$ & 18.9 & 29.5 & 28.9 & 33.7 \\
\hline $25-44$ & 20.5 & 32.0 & 28.1 & 30.5 \\
\hline $45-64$ & 20.9 & 33.5 & 25.4 & 26.6 \\
\hline $65+$ & 16.1 & 33.6 & 24.6 & 28.7 \\
\hline Married & 17.4 & 41.6 & 29.4 & 32.9 \\
\hline Divorced/Separated & 24.5 & 20.3 & 18.7 & 29.0 \\
\hline Widowed & 22.3 & 25.0 & 20.7 & \\
\hline Never Married & 23.2 & 24.1 & 24.9 & 29.8 \\
\hline
\end{tabular}

Notes: U-index is proportion of time that rating of sad, stressed or pain exceeds happy.

Source: GSS pooled 2000, 2002, 2004, 2006 - \% very happy. Eurobarometers for EU15, 2000-2006 \% very satisfied (Austria; Belgium; Denmark; Finland; France; Germany; Greece; Ireland; Italy; Luxembourg; Netherlands; Portugal; Spain; Sweden and UK). PATS Krueger et al (2007) Table 5.1 using Princeton Affect and Time Survey data. Latinobarometer $2005 \%$ very satisfied (Argentina; Bolivia; Brazil; Colombia; Costa Rica; Chile; Dominican Republic; Ecuador; El Salvador; Guatemala; Honduras; Mexico; Nicaragua; Panama; Paraguay; Peru; Uruguay and Venezuela. Education categories for the LB are $<9$ years schooling; 10-12 years and $>12$ years. 
Table 3a. Life satisfaction and country characteristics, France, Denmark, UK and USA

A) 4 step life satisfaction

\begin{tabular}{lcc} 
& \multicolumn{2}{c}{ K2S3 2006} \\
& Women \\
\cline { 2 - 3 } U.S. & $\frac{\text { France }}{1.1}$ \\
Not at all satisfied & 1.6 & 16.1 \\
Not very satisfied & 21.4 & 10.0 \\
Satisfied & 51.0 & 70.0 \\
Very Satisfied & 26.1 & 12.9 \\
Score & 3.00 & 2.94 \\
N & 810 & 816
\end{tabular}

\begin{tabular}{l}
\multicolumn{3}{c|}{ Eurobarometer $2000-2006$} \\
\begin{tabular}{c|c|c|} 
Women & Women & Women \\
France & Denmark & UK \\
\hline 4.5 & 0.6 & 2.2 \\
15.1 & 2.7 & 8.4 \\
64.5 & 31.7 & 56.6 \\
15.9 & 65.0 & 32.9 \\
2.92 & 3.62 & 3.21 \\
7,074 & 6,700 & 9,457
\end{tabular}
\end{tabular}

B) 10 step life satisfaction for women (WVS)

$\begin{array}{llclc} & \text { France } & \text { Denmark } & \text { UK } & \text { USA } \\ 1981-1984 & 6.75 & 8.27 & 7.55 & 7.73 \\ 1989-1993 & 6.82 & 8.07 & 7.65 & 7.65 \\ 1999-2004 & 6.97 & 8.23 & 7.68 & 7.65\end{array}$

C) World Database of Happiness - men and women combined

France Denmark UK USA

4 step life satisfaction

$\begin{array}{lllll}2001 & 2.90 & 3.59 & 3.17 & 3.35 \\ 2002 & 2.89 & 3.59 & 3.14 & 3.33 \\ 2003 & 2.86 & 3.56 & 3.16 & 3.41 \\ 2004 & 2.96 & 3.60 & 3.22 & 3.42\end{array}$

D) Macro data

$\begin{array}{lcccc} & \text { France } & \text { Denmark } & \text { UK } & \text { USA } \\ \text { GDP/capita (PPPUS\$2004) } & \$ 29,300 & \$ 31,914 & \$ 30,821 & \$ 39,676 \\ \text { Gini coefficient } & 32.7 & 24.7 & 36.0 & 40.8 \\ \text { Unemployment rate } & 8.6 \% & 3.3 \% & 5.4 \% & 4.7 \% \\ \text { Long-term unemployment } & 44.8 \% & 20.7 \% & 27.5 \% & 10.7 \% \\ \text { Youth unemployment } & 23.9 \% & 7.6 \% & 13.9 \% & 10.5 \%\end{array}$

Notes: score is obtained by calculating a weighted average of responses where $1=$ not at all satisfied, $2=$ not very satisfied, $3=$ satisfied and $4=$ very satisfied. Youth and long-term unemployment are both for males. Youth unemployment is for ages 15-24.

Data source: http://hdrstats.undp.org/indicators/\#L 
Table 3b. Suicide Rates (per 100,000)

\begin{tabular}{|c|c|c|c|c|c|c|c|c|c|c|c|c|}
\hline \multicolumn{13}{|c|}{ United States } \\
\hline & 1950 & 1955 & 1960 & 1965 & 1970 & 1975 & 1980 & 1985 & 1990 & 1995 & 2000 & 2002 \\
\hline Total & 7.6 & 10.2 & 10.6 & 11.1 & 11.5 & 12.7 & 11.8 & 12.3 & 12.4 & 11.9 & 10.4 & 11.0 \\
\hline Male & 17.7 & 15.9 & 16.4 & 16.7 & 16.7 & 18.9 & 18.6 & 19.9 & 20.4 & 19.8 & 17.1 & 17.9 \\
\hline Female & 2.5 & 4.5 & 4.9 & 6.1 & 6.5 & 6.8 & 5.4 & 5.1 & 4.8 & 4.4 & 4.0 & 4.2 \\
\hline \multicolumn{13}{|l|}{ France } \\
\hline & 1950 & 1955 & 1960 & 1965 & 1970 & 1975 & 1980 & 1985 & 1990 & 1995 & 2000 & 2003 \\
\hline Total & 15.2 & 15.9 & 15.8 & 15.0 & 15.4 & 15.8 & 19.4 & 22.5 & 20.0 & 20.6 & 18.4 & 18.0 \\
\hline Male & 23.7 & 24.6 & 23.9 & 23.0 & 22.8 & 22.9 & 28.0 & 33.1 & 29.6 & 30.4 & 27.9 & 27.5 \\
\hline Female & 7.2 & 7.8 & 8.2 & 7.5 & 8.4 & 9.0 & 11.1 & 12.7 & 11.1 & 10.8 & 9.5 & 9.1 \\
\hline \multicolumn{13}{|c|}{ Denmark } \\
\hline & 1950 & 1955 & 1960 & 1965 & 1970 & 1975 & 1980 & 1985 & 1990 & 1995 & 2000 & 2001 \\
\hline Total & 23.3 & 23.3 & 20.3 & 19.3 & 21.5 & 24.1 & 31.6 & 27.9 & 23.9 & 17.7 & 13.6 & 13.6 \\
\hline Male & 31.7 & 32.0 & 27.2 & 24.0 & 27.4 & 29.9 & 41.1 & 35.1 & 32.2 & 24.2 & 20.2 & 19.2 \\
\hline Female & 15.0 & 14.8 & 13.6 & 14.7 & 15.7 & 18.4 & 22.3 & 20.6 & 16.3 & 11.2 & 7.2 & 8.1 \\
\hline \multicolumn{13}{|l|}{ UK } \\
\hline & 1950 & 1955 & 1960 & 1965 & 1970 & 1975 & 1980 & 1985 & 1990 & 1995 & 1999 & 2004 \\
\hline Total & 9.5 & 10.7 & 10.7 & 10.4 & 7.9 & 7.5 & 8.8 & 9.0 & 8.1 & 7.4 & 7.5 & 7.0 \\
\hline Male & 12.7 & 13.6 & 13.3 & 12.2 & 9.4 & 9.0 & 11.0 & 12.4 & 12.6 & 11.7 & 11.8 & 10.8 \\
\hline Female & 6.5 & 8.0 & 8.2 & 8.7 & 6.5 & 6.0 & 6.7 & 5.8 & 3.8 & 3.2 & 3.3 & 3.3 \\
\hline
\end{tabular}

Source: http://www.who.int/mental health/prevention/suicide/country_reports/en/index.html 
Table 4a; Happiness equations, ISSP 1998 and 2001

\begin{tabular}{|c|c|c|c|c|}
\hline & \multicolumn{2}{|c|}{1998} & \multicolumn{2}{|c|}{2001} \\
\hline & (1) & (2) & (3) & (4) \\
\hline Denmark & $.6415(7.32)$ & $.6554(7.39)$ & $.2451(2.86)$ & $.2664(3.05)$ \\
\hline France & $-.2635(3.00)$ & $-.3977(4.49)$ & $.2699(3.22)$ & .3043 (3.59) \\
\hline UK & $.8500(10.55)$ & $.8920(10.97)$ & $.5855(7.64)$ & $.7097(9.16)$ \\
\hline Australia & $.6791(8.06)$ & $.6196(7.17)$ & $.2599(3.12)$ & $.2942(3.41)$ \\
\hline Austria & $.3595(4.02)$ & $.3139(3.48)$ & $.3252(3.63)$ & $.4093(4.52)$ \\
\hline Brazil & & & $1.2895(16.34)$ & $1.4270(17.10)$ \\
\hline Bulgaria & $-1.4468(16.31)$ & $-1.4724(16.39)$ & & \\
\hline Canada & $.2404(2.63)$ & $.0987(1.06)$ & $.5587(6.42)$ & $.5751(6.45)$ \\
\hline Chile & $-.5378(6.32)$ & $-.6176(7.20)$ & .4707 (5.64) & .5407 (6.39) \\
\hline Cyprus & $-.2714(2.95)$ & $-.4533(4.88)$ & $-.9342(10.26)$ & $-1.0880(11.83)$ \\
\hline Czech Republic & $-.3740(4.41)$ & $-.4048(4.73)$ & $-.5579(6.47)$ & $-.5132(5.87)$ \\
\hline East Germany & $-.6886(7.70)$ & $-.5614(6.25)$ & $-.3648(3.18)$ & $-.2484(2.16)$ \\
\hline Finland & & & $-.3058(3.65)$ & $-.3262(3.79)$ \\
\hline Hungary & $-1.5248(17.34)$ & $-1.4973(16.84)$ & $-.7982(9.71)$ & $-.6713(8.06)$ \\
\hline Ireland & $1.2023(13.53)$ & $1.2171(13.51)$ & & $.0850(1.02)$ \\
\hline Israel & $-.1655(1.88)$ & $-.3189(3.59)$ & $-.3637(4.10)$ & $-.4534(5.06)$ \\
\hline Italy & $-.3475(3.88)$ & $-.4527(5.03)$ & $-.6034(6.64)$ & $-.8020(8.56)$ \\
\hline Japan & $.0343(0.41)$ & $-.1062(1.26)$ & $.1487(1.76)$ & $.0985(1.15)$ \\
\hline Latvia & $-1.4895(17.63)$ & $-1.5736(18.41)$ & $-1.4145(15.85)$ & $-1.3995(15.50)$ \\
\hline Netherlands & $.7338(9.48)$ & $.7252(9.30)$ & & \\
\hline New Zealand & $.7760(8.70)$ & $.7544(8.31)$ & $.7155(8.27)$ & $.7782(8.80)$ \\
\hline Norway & $.2935(3.58)$ & $.2269(2.73)$ & $.0872(1.06)$ & $.0850(1.02)$ \\
\hline Philippines & $.2444(2.79)$ & $-.0038(0.04)$ & $.1119(1.28)$ & $.0772(0.87)$ \\
\hline Poland & $-.0188(0.21)$ & $-.0332(0.38)$ & $-.5691(6.61)$ & $-.5061(5.83)$ \\
\hline Portugal & $-.9207(10.49)$ & $-1.0417(11.82)$ & & \\
\hline Russia & $-1.3633(16.72)$ & $-1.4252(17.16)$ & $-2.5134(32.28)$ & $-2.5377(32.23)$ \\
\hline Slovenia & $-.7625(8.47)$ & $-.9077(9.99)$ & $-.5625(6.31)$ & $-.6460(7.17)$ \\
\hline Slovenia & $-.9608(11.40)$ & $-1.1135(13.04)$ & $-.5625(6.31)$ & $-.6459(7.17)$ \\
\hline South Africa & & & $-.1925(2.46)$ & $-.0077(0.10)$ \\
\hline Spain & $.1531(2.03)$ & .0883 (1.17) & $-.2714(3.20)$ & $-.2837(3.31)$ \\
\hline Sweden & $.2767(3.18)$ & $.1541(1.75)$ & & \\
\hline Switzerland & $.5572(6.49)$ & $.5453(6.28)$ & .7205 (8.12) & $.7698(8.52)$ \\
\hline USA & $.8065(9.49)$ & $.8325(9.72)$ & $.7800(8.98)$ & $.9193(10.45)$ \\
\hline Age & $-.0738(17.72)$ & & & $-.0630(15.17)$ \\
\hline $\mathrm{Age}^{2}$ & $.0006(14.76)$ & & & $.0006(13.29)$ \\
\hline Male & $-.0960(4.23)$ & & & $-.0180(0.80)$ \\
\hline Personal controls & No & Yes & No & Yes \\
\hline cut1 & -3.6133 & -5.4182 & -3.5164 & -4.9288 \\
\hline cut2 & -1.5153 & -3.2445 & -1.7275 & -3.0885 \\
\hline cut3 & 1.4123 & -.2039 & 1.1509 & -.1180 \\
\hline $\mathrm{N}$ & 37,875 & 37,521 & 35,950 & 35,219 \\
\hline Pseudo $\mathrm{R}^{2}$ & .0607 & .0857 & .0765 & .0964 \\
\hline
\end{tabular}

Source: 1998 and 2001 ISSP. Notes; personal controls are marital status and labor market status dummies. Excluded country West Germany. 'If you were to consider your life in general how happy would you say you are, on the whole - not at all happy; not very happy; fairly happy, very happy'. 
Table 4b. Happiness and role of the family from the ISSP 2002

\begin{tabular}{|c|c|c|c|c|}
\hline & & jiness & $\mathrm{Fal}$ & \\
\hline & (1) & (2) & (3) & (4) \\
\hline Denmark & & $-.1159(1.53)$ & & $.3825(4.95)$ \\
\hline France & & $-.3039(4.40)$ & & $-.4605(6.41)$ \\
\hline UK & & $.3613(5.65)$ & & $.3082(4.65)$ \\
\hline USA & $.6701(8.30)$ & $.4169(5.45)$ & $.7448(9.36)$ & $.3612(4.56)$ \\
\hline Age & $-.1084(7.26)$ & $-.0705(19.55)$ & $-.1032(7.06)$ & $-.0675(18.53)$ \\
\hline $\mathrm{Age}^{2}$ & $.0011(7.29)$ & $.0006(17.50)$ & $.0010(6.91)$ & $.0006(17.03)$ \\
\hline Male & $-.0261(0.35)$ & $.0507(2.68)$ & $-.0758(1.02)$ & $.1118(5.87)$ \\
\hline No formal education & $.5095(1.36)$ & $.0208(0.49)$ & $-.1011(0.28)$ & $.0432(1.05)$ \\
\hline Above lowest formal & $.2813(2.02)$ & $.1833(4.32)$ & $-.0020(0.01)$ & $.1848(4.43)$ \\
\hline Higher secondary & $.5644(3.97)$ & $.2459(5.81)$ & $.0738(0.21)$ & $.2191(5.28)$ \\
\hline Above secondary & $.5243(3.75)$ & $.2957(6.52)$ & $.0035(0.01)$ & $.2207(4.93)$ \\
\hline University degree & $.8726(6.44)$ & $.4026(8.92)$ & $.1145(0.33)$ & $.2392(5.37)$ \\
\hline Married & $.9005(9.00)$ & $.7009(26.23)$ & $1.1943(11.93)$ & $.8491(31.05)$ \\
\hline Widowed & $.0561(0.30)$ & $-.2500(5.54)$ & $.4089(2.24)$ & $-.1107(2.41)$ \\
\hline Divorced & $-.0866(0.63)$ & $-.2372(5.46)$ & $.0597(0.44)$ & $-.3134(6.96)$ \\
\hline Separated & $-.4838(2.16)$ & $-.3636(5.53)$ & $-.3306(1.53)$ & $-.5151(7.85)$ \\
\hline Public sector & $.0291(0.29)$ & $.0392(1.41)$ & $-.0114(0.12)$ & $.0050(0.18)$ \\
\hline Self-employed & $.0980(0.65)$ & $.1061(3.11)$ & $.1601(1.08)$ & $.0911(2.69)$ \\
\hline Unpaid family worker & $-.7075(0.91)$ & $.0398(0.33)$ & $.2213(0.25)$ & $-.0415(0.35)$ \\
\hline Unemployed & $-.2388(1.24)$ & $-.5482(12.92)$ & $-.2223(1.17)$ & $-.3923(9.24)$ \\
\hline Student & $.0559(0.28)$ & $.1459(3.13)$ & $.0872(0.42)$ & $.1028(2.16)$ \\
\hline Retired & $-.0991(0.67)$ & $-.0496(1.34)$ & $-.0267(0.18)$ & $-.0625(1.68)$ \\
\hline Housewife & $-.0016(0.01)$ & $.0363(1.01)$ & $-.0246(0.18)$ & $.0038(0.11)$ \\
\hline Disabled & $-.5181(1.04)$ & $-.4661(6.60)$ & $-.5115(1.11)$ & $-.3052(4.29$ \\
\hline Other labor mkt. & $-.3538(1.35)$ & $-.2712(4.43)$ & $-.5177(1.94)$ & $-.2909(4.77)$ \\
\hline Austria & & $.4277(6.34)$ & & $.5102(7.24)$ \\
\hline Brazil & & $.4371(6.13)$ & & $-.3380(4.64)$ \\
\hline Bulgaria & & $-1.6116(20.47)$ & & $-1.3513(16.66)$ \\
\hline Chile & & $.4715(6.41)$ & & $.5708(7.70)$ \\
\hline Cyprus & & $-.0927(1.16)$ & & $-.1089(1.38)$ \\
\hline Czech Republic & & $-.7562(10.08)$ & & $-.8577(11.23)$ \\
\hline East Germany & & $-.6619(6.41)$ & & $-.1039(0.98)$ \\
\hline Estonia & & $-.2654(4.06)$ & & $-.2251(3.37)$ \\
\hline Finland & & $-.3428(4.44)$ & & $-.3863(4.86)$ \\
\hline Flanders & & $-.3712(4.98)$ & & $-.2767(3.62)$ \\
\hline Hungary & & $-.5945(7.41)$ & & $-.2962(3.59)$ \\
\hline Ireland & & $-.0298(0.41)$ & & $.4107(5.34)$ \\
\hline Israel & & $-.2329(3.00)$ & & $.1679(2.13)$ \\
\hline Japan & & $.2953(3.70)$ & & $-.2731(3.40)$ \\
\hline Latvia & & $-1.1807(14.87)$ & & $-1.1642(14.13)$ \\
\hline Mexico & & $.5591(7.34)$ & & $.8134(10.61)$ \\
\hline Netherlands & & $-.2270(3.06)$ & & $-.1761(2.30)$ \\
\hline New Zealand & & $.2682(3.30)$ & & $.1114(1.34)$ \\
\hline
\end{tabular}




\begin{tabular}{|c|c|c|c|c|}
\hline Norway & & $-.1811(2.48)$ & & $-.0272(0.37)$ \\
\hline Philip & & $.1092(1.37)$ & & $.0601(0.74)$ \\
\hline Poland & & $-.7878(10.48)$ & & $-.3929(5.11)$ \\
\hline Portugal & & $-.3820(4.82)$ & & $-.2205(2.75)$ \\
\hline Russia & & $-1.0997(15.45)$ & & $-1.0436(14.00)$ \\
\hline Slovakia & & $-.9487(12.21)$ & & $-.8533(10.61)$ \\
\hline Slovenia & & $-.4791(6.15)$ & & $-.1456(1.81)$ \\
\hline Sweden & & $-.2411(3.06)$ & & $.0495(0.60)$ \\
\hline Switzerland & & $.3338(4.28)$ & & $.2935(3.68)$ \\
\hline Taiwan & & $-.3847(5.59)$ & & $-.4845(6.95)$ \\
\hline West Germany & & $-.4315(5.36)$ & & $-.0499(0.60)$ \\
\hline Cut1 & -8.1600 & -7.5073 & -6.3764 & -6.4968 \\
\hline Cut2 & -6.0305 & -5.9530 & -5.2860 & -5.4063 \\
\hline Cut3 & -4.5138 & -4.5258 & -3.9864 & -4.1993 \\
\hline Cut4 & -3.0443 & -2.9599 & -3.0898 & -3.0322 \\
\hline Cut5 & -.7444 & -.8420 & -1.3159 & -1.1549 \\
\hline Cut6 & 1.1677 & 1.1391 & .2919 & .7428 \\
\hline Pseudo $\mathrm{R}^{2}$ & .0460 & .0456 & .0444 & .0442 \\
\hline $\mathrm{N}$ & 2,885 & 44,468 & 2,859 & 43,657 \\
\hline
\end{tabular}

Notes: excluded categories: lowest formal qualification and private sector employee and Australia. T-statistics in parentheses. Columns 1 and 3 are USA and France only. Columns 1 are 2 are responses to the question 'If you were to consider your life in general, how happy or unhappy would you say you are, on the whole?' (Respondents answered on a 7-point scale). Column 2 refers to the following question. 'All things considered, how satisfied are you with your family life?' (Respondents answered on a 7-point scale). Scale is from completely unhappy; very unhappy; fairly unhappy; neither; fairly happy; very happy and completely happy. 
Table 5. Wanting to spend time with the family - ranked by \% in 2005 (\%)

\begin{tabular}{|c|c|c|}
\hline & 1997 & 2005 \\
\hline United States & 41.9 & 55.3 \\
\hline Dominican Republic & & 55.3 \\
\hline Mexico & & 43.5 \\
\hline Philippines & 50.8 & 38.7 \\
\hline Canada & 23.3 & 37.8 \\
\hline South Africa & & 36.7 \\
\hline France & 34.3 & 33.7 \\
\hline Israel & 35.6 & 33.5 \\
\hline New Zealand & 23.9 & 28.6 \\
\hline Australia & & 28.5 \\
\hline Ireland & & 28.1 \\
\hline United Kingdom & 31.6 & 27.7 \\
\hline East Germany & 29.8 & 25.7 \\
\hline Sweden & 27.9 & 25.7 \\
\hline Norway & 25.5 & 24.8 \\
\hline Slovenia & 26.3 & 23.3 \\
\hline West Germany & 24.5 & 21.4 \\
\hline Denmark & 21.0 & 21.2 \\
\hline Portugal & 34.1 & 19.8 \\
\hline Russia & 23.9 & 19.3 \\
\hline Hungary & 19.1 & 18.7 \\
\hline Switzerland & 22.8 & 17.1 \\
\hline Bulgaria & 14.7 & 16.7 \\
\hline Czech Republic & 25.2 & 15.1 \\
\hline Spain & 7.8 & 15.0 \\
\hline Finland & & 14.4 \\
\hline South Korea & & 13.1 \\
\hline Japan & 7.5 & 9.1 \\
\hline Taiwan & & 8.9 \\
\hline Cyprus & 25.2 & 7.2 \\
\hline Bangladesh & 5.1 & \\
\hline Italy & 15.7 & \\
\hline Latvia & 15.6 & \\
\hline Netherlands & 14.6 & \\
\hline Poland & 23.4 & \\
\hline
\end{tabular}

Notes: Question asked is 'Suppose you could change the way you spend your time, spending more time on some things and less time on others. Which of the things on the following list would you like to spend more time on, which would you like to spend less time on and which would you like to spend the same amount of time on as now? Time with your family?' (1= Much more time; $2=\mathrm{A}$ bit more time; $3=$ Same time as now; $4=$ A bit less time; $5=$ Much less time). tabulated are the proportions saying 'much more time with their family'.

Source: International Social Survey Programme $1997(n=32,783)$ and $2005(n=43,440)$. 
Table 6. Life satisfaction and happiness - World Values Survey, 1981-2004 (ordered logits)

\begin{tabular}{|c|c|c|c|c|}
\hline \multirow[b]{2}{*}{ Denmark } & \multicolumn{2}{|c|}{ Life satisfaction } & \multicolumn{2}{|c|}{ Happiness } \\
\hline & $.9958(31.91)$ & $1.0033(31.47)$ & $.8450(24.83)$ & $.8625(24.78)$ \\
\hline France & $-.1073(3.88)$ & $-.1470(5.11)$ & . $4227(13.64)$ & . $4426(13.74)$ \\
\hline UK & $.5004(22.79)$ & $.2823(11.91)$ & $.8036(30.05)$ & $.6773(23.67)$ \\
\hline USA & $.5197(23.77)$ & $.3480(14.59)$ & $6959(28.04)$ & $.5800(21.41)$ \\
\hline Age & & -.0377 (22.09) & & $-.0491(26.11)$ \\
\hline $\mathrm{Age}^{2}$ & & $.00046(24.75)$ & & $.00050(24.63)$ \\
\hline Male & & $-.0765(8.45)$ & & $-.0848(8.38)$ \\
\hline Married & & $1907(14.98)$ & & $.4063(28.44)$ \\
\hline Living together & & $.2133(10.00)$ & & $.3131(13.04)$ \\
\hline Divorced & & $-.3442(14.18)$ & & $-.3737(13.82)$ \\
\hline Separated & & $-.4235(12.29)$ & & $-.4364(11.36)$ \\
\hline Widowed & & $-.4123(18.33)$ & & $-.4927(19.98)$ \\
\hline Part-time employee & & $-.0252(1.56)$ & & $-.0064(0.36)$ \\
\hline Self-employed & & $.0361(2.32)$ & & $.0612(3.50)$ \\
\hline Retired & & $-.2202(12.43)$ & & $-.2276(11.73)$ \\
\hline Home worker & & $.0607(4.21)$ & & $.1494(9.35)$ \\
\hline Student & & $-.0158(0.84)$ & & $.0824(3.87)$ \\
\hline Unemployed & & $-.6850(40.79)$ & & $-.4884(26.36)$ \\
\hline Other & & $-.2326(6.80)$ & & $-.0245(0.64)$ \\
\hline cut1 & -3.4057 & -4.0057 & -3.6190 & -4.3648 \\
\hline cut2 & -2.8445 & -3.4499 & -1.4905 & -2.2030 \\
\hline cut3 & -2.2542 & -2.8627 & 1.0105 & .4280 \\
\hline cut 4 & -1.8110 & -2.4062 & & \\
\hline cut5 & -1.0434 & -1.6032 & & \\
\hline cut6 & -.5878 & -1.1143 & & \\
\hline cut7 & -.0103 & -.4836 & & \\
\hline cut8 & .8544 & .4453 & & \\
\hline cut9 & 1.5985 & 1.2323 & & \\
\hline Year dummies & 19 & 19 & 19 & 19 \\
\hline Schooling dummies & 0 & 10 & 0 & 10 \\
\hline $\mathrm{N}$ & 263,097 & 188,529 & 257,881 & 185,629 \\
\hline Pseudo $\mathrm{R}^{2}$ & 0.0112 & .0191 & .0131 & .0336 \\
\hline
\end{tabular}

Notes: excluded categories - full-time employees. Excluded countries are Albania ; Algeria; Argentina; Armenia; Australia; Austria; Azerbaijan; Bangladesh; Belarus; Belgium; Bosnia and Herzegovina; Brazil; Bulgaria; Canada; Chile; China; Colombia; Croatia; Czech Republic; Dominican Republic; Egypt; El Salvador; Estonia; Finland; Georgia; Germany; Greece; Hungary; Iceland; India; Indonesia; Iran; Iraq; Ireland; Israel; Italy; Japan; Jordan; Korea; Kyrgyzstan; Latvia; Lithuania; Luxembourg; Macedonia ; Malta; Mexico; Moldova; Morocco; Netherlands; New Zealand; Nigeria; Norway; Pakistan; Peru; Philippines; Poland; Portugal; Puerto Rico; Romania; Russia; Saudi Arabia; Serbia and Montenegro; Singapore; Slovakia; Slovenia; South Africa; Spain; Sweden; Switzerland; Taiwan; Tanzania; Turkey; Uganda; Ukraine; Uruguay; Venezuela; Vietnam and Zimbabwe. 
Table 7. Happiness - European Quality of Life Survey, 2003, (ordered logits)

\begin{tabular}{|c|c|c|c|c|c|c|}
\hline \multirow[b]{2}{*}{ Austria } & \multicolumn{3}{|c|}{ Life satisfaction } & \multicolumn{3}{|c|}{ ness } \\
\hline & $.4090(5.10)$ & $.4271(5.27)$ & $.4289(4.49)$ & $.1428(1.79)$ & $.1567(1.93)$ & $.2364(2.47)$ \\
\hline Belgium & $.0382(0.49)$ & $.0601(0.76)$ & $.1178(1.21)$ & $-.1505(1.94)$ & $-.1305(1.64)$ & $.0248(0.26)$ \\
\hline Bulgaria & $-2.5368(31.15)$ & $-2.4404(29.46)$ & $-1.5446(14.49)$ & $-1.9696(23.99)$ & $-1.7896(21.30)$ & $-1.0179(9.45)$ \\
\hline Cyprus & $-.0981(1.04)$ & $-.5691(5.95)$ & $-.3993(3.47)$ & $-.0203(0.22)$ & $-.5992(6.26)$ & $-.5023(4.35)$ \\
\hline Czech Republic & $-.8607(10.67)$ & $-.8486(10.29)$ & $-.4109(3.99)$ & $-.6880(8.65)$ & $-.5519(6.77)$ & $-.0797(0.78)$ \\
\hline Denmark & $1.1301(14.11)$ & $.9682(11.68)$ & $.9946(10.42)$ & $.4876(6.17)$ & $.3591(4.35)$ & $.4889(5.15)$ \\
\hline Estonia & $-1.4143(15.42)$ & $-1.1176(11.94)$ & $-.5002(4.52)$ & $-1.0424(11.19)$ & $-.5971(6.27)$ & $-.0060(0.05)$ \\
\hline Finland & $.7337(9.31)$ & $.8776(10.95)$ & .9307 (10.07) & $.2892(3.73)$ & $.5505(6.87)$ & $.6638(7.17)$ \\
\hline France & $-.5155(6.67)$ & $-.5407(6.87)$ & $-.5271(5.60)$ & $-.5903(7.70)$ & $-.6114(7.77)$ & $-.5381(5.72)$ \\
\hline Germany & $-.0595(0.75)$ & $.0175(0.22)$ & $.1688(1.77)$ & $-.1787(2.28)$ & $-.0340(0.43)$ & $.1886(1.98)$ \\
\hline Greece & $-.5031(6.23)$ & $-.7647(9.29)$ & $-.4913(4.61)$ & $-.2915(3.64)$ & $-.5331(6.53)$ & $-.1970(1.86)$ \\
\hline Hungary & $-1.3205(16.37)$ & $-1.1253(13.75)$ & $-.6237(6.28)$ & $-.7612(9.36)$ & $-.4981(6.02)$ & $-.0120(0.12)$ \\
\hline Ireland & $.3055(3.83)$ & $.1194(1.48)$ & $-.0726(0.66)$ & .3099 (3.82) & $.0534(0.65)$ & $-.0187(0.17)$ \\
\hline Italy & $-.2241(2.89)$ & $-.3280(4.15)$ & $-.2784(2.82)$ & $-.3707(4.79)$ & $-.5112(6.42)$ & $-.3979(3.99)$ \\
\hline Latvia & $-1.6794(21.04)$ & $-1.2665(15.48)$ & $-.5631(5.52)$ & $-1.4945(18.57)$ & $-.9902(11.95)$ & $-.3624(3.52)$ \\
\hline Lithuania & $-1.8015(22.55)$ & $-1.4053(17.23)$ & $-.6031(5.91)$ & $-1.4176(17.51)$ & $-.9009(10.83)$ & $-.1988(1.92)$ \\
\hline Luxembourg & $.3766(4.04)$ & $.3448(3.61)$ & $.2902(2.38)$ & $.1996(2.19)$ & $.1745(1.84)$ & $.2715(2.24)$ \\
\hline Malta & $-.0742(0.80)$ & $-.1755(1.84)$ & $.0016(0.01)$ & $.0692(0.75)$ & $.0152(0.16)$ & $.1816(1.49)$ \\
\hline Netherlands & $.0326(0.43)$ & $.1135(1.46)$ & $.1602(1.70)$ & $-.2649(3.46)$ & $-.2190(2.76)$ & $-.1452(1.52)$ \\
\hline Poland & $-1.1107(13.66)$ & $-.7742(9.34)$ & $-.2635(2.61)$ & $-.9345(11.47)$ & $-.5367(6.40)$ & $-.0732(0.72)$ \\
\hline Portugal & $-1.3621(17.13)$ & $-.9364(11.45)$ & $-.5650(5.66)$ & $-1.1363(14.13)$ & $-.6304(7.62)$ & $-.2909(2.88)$ \\
\hline Romania & $-1.0805(13.45)$ & $-.8107(9.93)$ & $.1680(1.59)$ & $-.6932(8.76)$ & $-.3469(4.29)$ & $.4908(4.66)$ \\
\hline Slovakia & $-1.5512(19.34)$ & $-1.5434(18.76)$ & $-1.1304(11.09)$ & $-1.3157(16.74)$ & $-1.2635(15.61)$ & $-.8267(8.23)$ \\
\hline Slovenia & $-.3313(3.61)$ & $-.2557(2.75)$ & $.0524(0.48)$ & $-.4307(4.72)$ & $-.3449(3.70)$ & $-.0521(0.48)$ \\
\hline Spain & $.0092(0.12)$ & $.0423(0.52)$ & $.2027(2.02)$ & $-.0578(0.72)$ & $-.0038(0.05)$ & $.1765(1.74)$ \\
\hline Sweden & $.4545(5.70)$ & $.3178(3.90)$ & $.3886(4.14)$ & $.1275(1.61)$ & $.0330(0.41)$ & $.1446(1.54)$ \\
\hline Turkey & $-1.5390(18.43)$ & -1.4167 (16.39) & $-.7061(6.83)$ & $-1.2119(14.74)$ & $-1.1451(13.31)$ & $-.5424(5.24)$ \\
\hline Age & & $-.0372(8.56)$ & $-.0435(8.79)$ & & $-.0301(6.89)$ & $-.0352(7.09)$ \\
\hline $\mathrm{Age}^{2}$ & & $.0004(11.16)$ & $.0005(11.11)$ & & $.0003(7.70)$ & $.00038(7.72)$ \\
\hline Male & & $-.1795(7.43)$ & $-.1942(7.11)$ & & $-.1817(7.44)$ & $-.1801(6.55)$ \\
\hline 16-19 yrs schooling & & $.1903(5.72)$ & $.1360(3.60)$ & & $.1829(5.44)$ & $.1370(3.59)$ \\
\hline
\end{tabular}




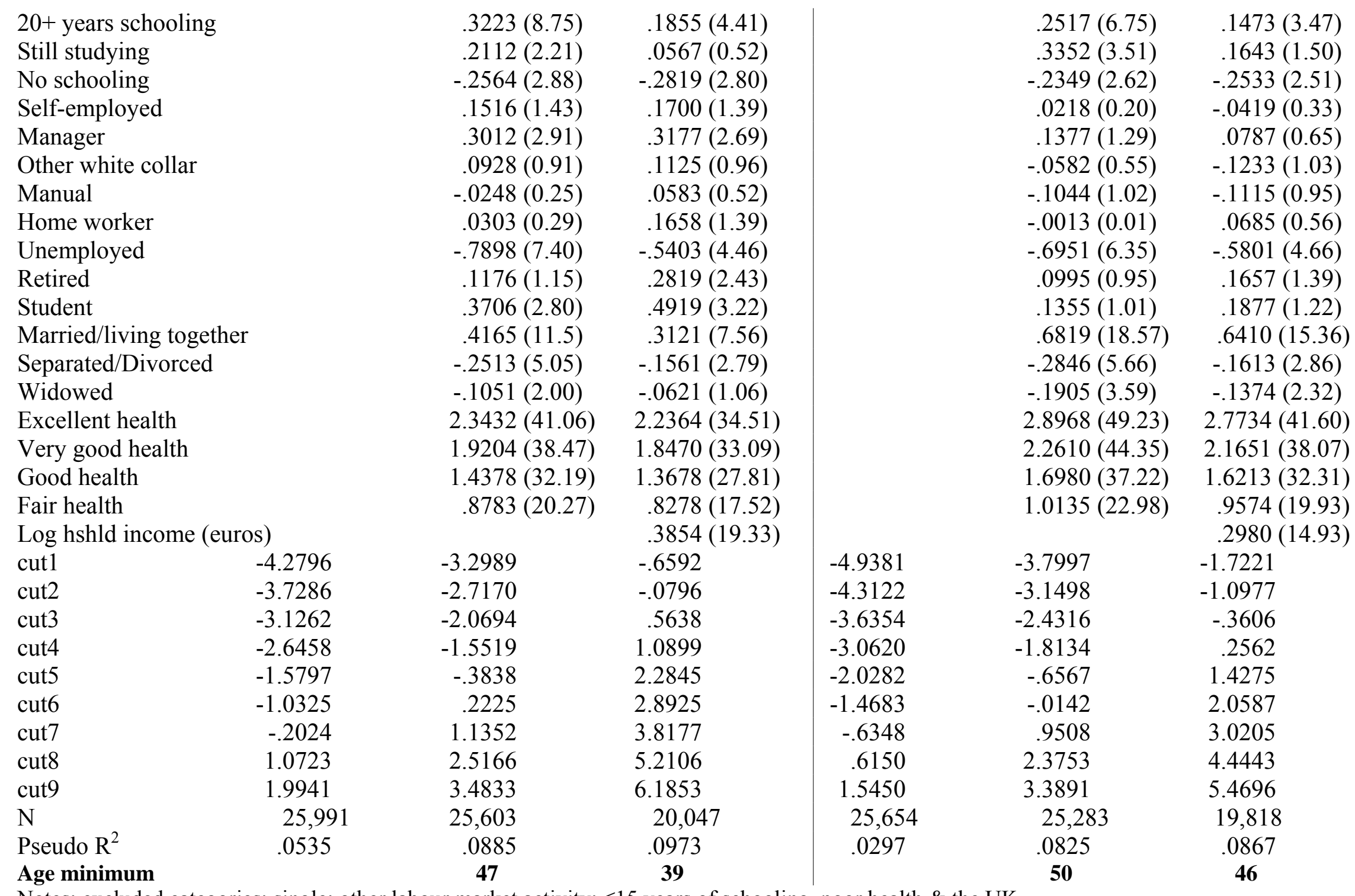


Table 8. Happiness, Life Satisfaction: European Social Survey, 2002 (ordered logits)

$\begin{array}{lclcl} & \text { Happiness } & \text { Happiness } & \text { Life satisfaction } & \text { Life satisfaction } \\ \text { France } & -.0016(0.03) & .0588(1.24) & -.5082(10.71) & -.4803(10.03) \\ \text { Denmark } & .8828(19.15) & .7462(16.01) & 1.1833(25.38) & 1.0605(22.55) \\ \text { UK } & .2033(5.01) & .1386(3.39) & -.0617(1.55) & -.1435(3.57) \\ \text { Married } & .5126(19.35) & .4891(18.42) & .2702(10.25) & .2339(8.86) \\ \text { Separated } & -.4287(5.73) & -.4585(6.10) & -.4754(6.39) & -.5149(6.86) \\ \text { Divorced } & -.1309(3.10) & -.1249(2.96) & -.2130(5.06) & -.2062(4.89) \\ \text { Widowed } & -.4401(10.00) & -.4067(9.26) & -.4055(9.26) & -.3704(8.48) \\ \text { Age } & -.0789(24.00) & -.0634(19.24) & -.0725(22.14) & -.0564(17.17) \\ \text { Age } & .0007(23.77) & .0007(21.98) & .0007(23.77) & .0007(21.95) \\ \text { Male } & -.1421(7.85) & -.1807(9.95) & -.1550(8.59) & -.1967(10.86) \\ \text { Schooling } & .0403(17.03) & .0224(9.41) & .0486(20.62) & .0302(12.68) \\ \text { Self-employed } & -.0461(1.45) & -.0811(2.54) & -.0575(1.81) & -.0879(2.76) \\ \text { Not employed } & -.2922(13.25) & -.1454(6.53) & -.3163(14.36) & -.1678(7.55) \\ \text { Good health } & & -.5999(26.65) & & -.5906(26.25) \\ \text { Fair health } & & -1.2547(45.77) & & -1.2830(46.88) \\ \text { Bad health } & & -2.1052(47.99) & & -2.1141(48.80) \\ \text { Very bad health } & & -2.9244(34.24) & & -3.0003(36.15) \\ \text { cut1 } & -6.3055 & -6.8664 & -5.0623 & -5.6024 \\ \text { cut2 } & -5.6224 & -6.1758 & -4.5712 & -5.0994 \\ \text { cut3 } & -4.9425 & -5.4806 & -4.0161 & -4.5278 \\ \text { cut4 } & -4.2389 & -4.7518 & -3.3945 & -3.8793 \\ \text { cut5 } & -3.7357 & -4.2258 & -2.9508 & -3.4121 \\ \text { cut6 } & -2.7478 & -3.1797 & -2.1598 & -2.5686 \\ \text { cut7 } & -2.2507 & -2.6484 & -1.7411 & -2.1194 \\ \text { cut8 } & -1.4475 & -1.7908 & -1.0251 & -1.3520 \\ \text { cut9 } & -.2258 & -.5009 & .1222 & -.1381 \\ \text { cut10 } & .9345 & .6989 & 1.1579 & .9339 \\ \text { N } & 40,903 & 40,879 & 40,852 & 40,825 \\ \text { Pseudo R } & .0149 & .0382 & .0138 & .0369 \\ \text { Age minimum } & 56 & 45 & 52 & 40 \\ & & & & \end{array}$

Notes; Excluded categories; very good health; single and employee plus Austria, Belgium, Czech Republic, Finland, Germany, Greece, Hungary, Ireland, Israel, Italy, Luxembourg, Netherlands, Norway, Poland, Portugal, Slovenia, Spain, Sweden and Switzerland. 
Table 9. Life satisfaction, Europe, Eurobarometer 2002 (ordered logits).

\begin{tabular}{|c|c|c|}
\hline ge & $-.0686(10.97)$ & $-.0524(8.26)$ \\
\hline $\mathrm{Age}^{2}$ & $.0006(10.56)$ & $.0005(9.03)$ \\
\hline Male & $-.0956(2.79)$ & $-.1366(3.94)$ \\
\hline ALS 16-19 & $.2396(5.51)$ & $.1616(3.67)$ \\
\hline $\mathrm{ALS} \geq 20$ & $.3558(6.95)$ & $.2533(4.89)$ \\
\hline Still studying & .4607 (4.83) & $.1785(1.84)$ \\
\hline Married & .3649 (6.24) & $.3094(5.23)$ \\
\hline Remarried & $.1566(1.12)$ & $.1712(1.22)$ \\
\hline Living as married & $.0441(0.65)$ & $.0519(0.76)$ \\
\hline Lived together & $-.4266(5.12)$ & $-.4029(4.80)$ \\
\hline Divorced & $-.3551(4.18)$ & $-.3256(3.80)$ \\
\hline Separated & $-.3424(2.73)$ & $-.2905(2.30)$ \\
\hline Widowed & $-.2354(2.75)$ & $-.2528(2.93)$ \\
\hline Home worker & $-.0752(1.12)$ & $-.2046(3.03)$ \\
\hline Unemployed & $-.6153(6.94)$ & $-.7256(8.15)$ \\
\hline Austria & $.3848(4.33)$ & $.3325(3.70)$ \\
\hline Denmark & $1.3696(15.04)$ & $1.3512(14.55)$ \\
\hline East Germany & $-.8624(9.94)$ & $-.7610(8.70)$ \\
\hline Finland & .4217 (4.79) & $.5945(6.67)$ \\
\hline France & $-.7296(8.29)$ & $-.6743(7.60)$ \\
\hline Greece & $-1.6273(18.30)$ & $-1.6692(18.48)$ \\
\hline Ireland & $.4194(4.68)$ & $.3555(3.92)$ \\
\hline Italy & $-.3468(3.93)$ & $-.2360(2.64)$ \\
\hline Luxembourg & $.8863(8.56)$ & $1.0032(9.57)$ \\
\hline Netherlands & .7914 (8.97) & $.9653(10.79)$ \\
\hline Portugal & $-1.6154(18.32)$ & $-1.2698(14.17)$ \\
\hline Spain & $-.2256(2.52)$ & $-.1340(1.48)$ \\
\hline Sweden & $.8549(9.65)$ & $.9918(11.03)$ \\
\hline UK & $.4863(5.85)$ & $.5822(6.93)$ \\
\hline West Germany & $-.2427(2.75)$ & $-.1162(1.31)$ \\
\hline Good health & & $-.6605(16.25)$ \\
\hline Fair health & & $-1.2178(24.90)$ \\
\hline Bad health & & $-1.8047(25.42)$ \\
\hline Very bad health & & $-2.4710(19.85)$ \\
\hline cut1 & -5.7366 & -6.2917 \\
\hline cut 2 & -3.9623 & -4.4689 \\
\hline cut3 & -2.7567 & -3.2146 \\
\hline cut4 & .1500 & -.1654 \\
\hline $\mathrm{N}$ & 16,032 & 15,992 \\
\hline Pse & .0911 & .1197 \\
\hline Age minimum & 57 & 52 \\
\hline
\end{tabular}

Source: Eurobarometer \#57.2; Health Issues, Cross-Border Purchases, and National Identities, April-June 2002. Notes: excluded categories; ALS $<16$; retired, Belgium, excellent health and single. Equations also include 13 occupation dummies. 
Table 10. Life satisfaction in Europe, Eurobarometers: 1975-2006 (ordered logits).

\begin{tabular}{|c|c|c|c|c|c|}
\hline & $1975-1989$ & 1990-1999 & $2000-2006$ & $1975-2006$ & $1975-2006$ \\
\hline France & $-1.5161(88.25)$ & $-1.4750(68.29)$ & $-1.3120(52.90)$ & $-1.4516(23.07)$ & $-1.4453(123.72)$ \\
\hline Denmark & $.5820(33.06)$ & $.6031(26.85)$ & .7707 (30.27) & $.6346(52.57)$ & $.6311(52.64)$ \\
\hline UK & $-.4656(28.88)$ & $-.5582(27.77)$ & $-.3871(16.72)$ & $-.4738(42.96)$ & $-.4685(42.73)$ \\
\hline Age & $-.0389(24.25)$ & $-.0389(20.22)$ & -.0365 (17.97) & $-.0379(36.35)$ & $-.0439(51.02)$ \\
\hline $\mathrm{Age}^{2}$ & $.00047(27.08)$ & $.00043(21.14)$ & $.00043(19.86)$ & $.00044(39.84)$ & $.00047(51.96)$ \\
\hline Male & $-.1754(18.19)$ & $-.0995(9.31)$ & $-.0843(7.04)$ & $-.1275(20.83)$ & $-.0942(18.76)$ \\
\hline Married & $.3341(25.83)$ & $.3063(20.17)$ & $.5527(31.33)$ & $.3630(42.50)$ & $.3511(49.32)$ \\
\hline Living together & $.0490(1.93)$ & $.1442(6.18)$ & $.2338(10.27)$ & $.1268(9.42)$ & $.1562(14.23)$ \\
\hline Divorced & $-.6085(21.31)$ & $-.4494(16.53)$ & $-.3219(11.68)$ & $-.4759(30.20)$ & $-.4055(31.47)$ \\
\hline Separated & $-.7687(18.55)$ & $-.5679(12.91)$ & $-.4587(10.78)$ & $-.6017(24.65)$ & $-.5303(25.42)$ \\
\hline Widowed & $-.3319(16.10)$ & $-.2200(8.97)$ & $-.1292(4.59)$ & $-.2566(18.71)$ & $-.2314(20.58)$ \\
\hline ALS 16-19 & $.2485(24.71)$ & $.1778(13.86)$ & $.1819(11.16)$ & $.2137(30.26)$ & $.2234(37.68)$ \\
\hline $\mathrm{ALS} \geq 20$ & $.4407(33.33)$ & $.3836(25.62)$ & $.4729(25.82)$ & $.4385(51.61)$ & $.4622(66.14)$ \\
\hline Still studying & $.4254(20.90)$ & $.4591(18.34)$ & $.6357(21.44)$ & $.4998(36.08)$ & $.4997(44.35)$ \\
\hline Self-employed & $.0801(5.40)$ & $.0167(0.88)$ & $.0628(2.81)$ & $.0514(4.97)$ & $.0358(4.33)$ \\
\hline Home worker & $-.0332(2.52)$ & $-.0594(3.50)$ & $-.1582(7.87)$ & $-.0510(5.60)$ & $-.0412(5.34)$ \\
\hline Retired & $-.0235(1.37)$ & $-.0950(5.01)$ & $-.1389(6.75)$ & $-.0863(8.02)$ & $-.1115(12.76)$ \\
\hline Unemployed & $-1.0206(54.66)$ & $-1.0112(49.64)$ & $-1.1590(46.81)$ & $-1.0593(88.25)$ & -.9557 (95.69) \\
\hline Belgium & $-.5811(34.07)$ & $-.7433(34.84)$ & $-.8530(34.71)$ & $-.6852(58.64)$ & $-.6809(58.52)$ \\
\hline Germany & $-.8913(52.16)$ & $-1.2599(66.97)$ & $-1.3673(62.25)$ & $-1.1622(07.17)$ & $-1.1457(106.75)$ \\
\hline Ireland & $-.4684(26.80)$ & $-.3616(16.67)$ & $-.3109(12.60)$ & $-.3968(33.38)$ & $-.3974(33.62)$ \\
\hline Italy & $-1.7333(99.51)$ & $-1.3532(62.52)$ & $-1.4872(58.95)$ & $-1.5650(31.22)$ & $-1.5468(131.58)$ \\
\hline Luxembourg & $-.2219(8.95)$ & $-.1188(4.43)$ & $-.1432(5.02)$ & $-.1594(10.48)$ & $-.1523(10.04)$ \\
\hline Austria & & & & & $-.7195(41.96)$ \\
\hline Bulgaria & & & & & $-3.4622(108.59)$ \\
\hline Croatia & & & & & $-1.6853(49.75)$ \\
\hline Cyprus & & & & & $-.7811(22.28)$ \\
\hline Czech Republic & & & & & $-1.4738(46.91)$ \\
\hline Estonia & & & & & $-1.9726(61.17)$ \\
\hline Finland & & & & & $-.6119(36.28)$ \\
\hline Greece & & & & & $-1.9742(156.20)$ \\
\hline
\end{tabular}




\section{Hungary \\ Latvia \\ Lithuania \\ Malta \\ Norway \\ Poland \\ Portugal \\ Romania \\ Slovakia \\ Slovenia \\ Spain \\ Sweden \\ Turkey}

Year dummies

cut1

cut2

cut3

$\mathrm{N}$

Pseudo $\mathrm{R}^{2}$

Age minimum

14

$$
\begin{array}{r}
-4.6814 \\
-3.0561 \\
-.2110
\end{array}
$$

234,939

0731

41
7

-4.8268
-2.9365
-.2103

164,693
.0656
$\mathbf{4 5}$

$$
\begin{array}{r}
-5.0042 \\
-3.1052 \\
.0150 \\
130,077 \\
.0908 \\
\mathbf{4 2}
\end{array}
$$

$$
\begin{gathered}
-2.3950(74.57) \\
-2.2816(71.80) \\
-2.3225(71.07) \\
-.8704(18.67) \\
-.0103(0.40) \\
-1.7470(52.54) \\
-1.8885(142.58) \\
-2.8584(87.56) \\
-2.2004(70.75) \\
-.8661(26.28) \\
-1.0737(81.08) \\
-.0893(5.27) \\
-1.2908(34.25)
\end{gathered}
$$

29

29

$\begin{array}{cc}-4.7075 & -4.8679 \\ -2.9500 & -3.0738 \\ -.0900 & -.2416 \\ & \\ 529,709 & 768,993 \\ .0749 & .0845 \\ \mathbf{4 3} & \mathbf{4 7}\end{array}$

43

Source: Eurobarometers, 1975-2006. Excluded categories; single, employee; ALS<16 and Netherlands. No data for 1996. 
Table 11. Happiness in the US (ordered logits).

\begin{tabular}{|c|c|c|c|c|}
\hline & Happiness & $\begin{array}{l}\text { Financial } \\
\text { Situation }\end{array}$ & $\begin{array}{c}\text { Family } \\
\text { Situation }\end{array}$ & Health \\
\hline & 1973-2006 & 1973-2006 & 1973-1994 & $1972-2006$ \\
\hline Age & $-.0168(4.11)$ & $-.0209(5.32)$ & $-.0171(2.55)$ & $-.0615(14.51)$ \\
\hline $\mathrm{Age}^{2}$ & $.0002(5.31)$ & $.0004(9.82)$ & $.0002(2.45)$ & $.0004(9.86)$ \\
\hline Married & $.7629(26.65)$ & $.1593(5.87)$ & $1.4303(35.82)$ & $.2514(8.88)$ \\
\hline Widowed & $-.3187(7.05)$ & $-.2519(5.87)$ & $.4710(7.89)$ & $-.0094(0.96)$ \\
\hline Divorced & $-.2303(6.08)$ & $-.5496(15.13)$ & $.1492(2.78)$ & $-.0629(1.64)$ \\
\hline Separated & $-.4843(8.56)$ & $-.6057(11.27)$ & $-.1039(1.42)$ & $-.2047(3.57)$ \\
\hline Male & $-.1769(8.42)$ & $.0107(0.54)$ & $-.3776(13.06)$ & $-.0520(2.39)$ \\
\hline Years schooling & $.0570(17.33)$ & .0787 (24.99) & $.0271(6.33)$ & $.1420(40.53)$ \\
\hline Black & $-.4233(14.74)$ & $-.5367(19.62)$ & $-.1456(3.97)$ & $-.3020(10.45)$ \\
\hline Other race & $-.1588(3.23)$ & $-.1035(2.24)$ & $.0174(0.20)$ & $.3007(6.11)$ \\
\hline Part-time & $-.1178(3.61)$ & $-.2360(7.52)$ & $-.1053(2.39)$ & $-.1988(5.82)$ \\
\hline Temp work & $-.2791(4.28)$ & $-.1396(2.22)$ & $-.0703(0.82)$ & $-.4426(6.44)$ \\
\hline Unemployed & $-.7613(13.37)$ & $-1.2248(21.38)$ & $-.0498(0.71)$ & $-.4486(7.73)$ \\
\hline Retired & $-.0222(0.55)$ & $-.1763(4.60)$ & $-.0705(1.33)$ & $-.6291(14.85)$ \\
\hline Student & $.1004(1.75)$ & $-.0141(0.26)$ & $.0233(0.31)$ & $-.2497(4.19)$ \\
\hline Home worker & $-.1206(3.99)$ & $-.1416(4.90)$ & $-.1765(4.60)$ & $-.5754(18.03)$ \\
\hline Other & $-.6738(9.12)$ & $-.8077(11.36)$ & $-.2245(2.15)$ & $-1.9501(24.90)$ \\
\hline Self-employed & $.1363(3.89)$ & $.1390(4.10)$ & $.0257(0.54)$ & $.2398(6.46)$ \\
\hline cut1 & -1.4343 & -.1456 & -3.5776 & -3.5952 \\
\hline cut2 & 1.4994 & 1.9331 & -2.7383 & -1.6977 \\
\hline cut3 & & & -2.1230 & .5157 \\
\hline cut4 & & & -1.2882 & \\
\hline cut5 & & & -.5270 & \\
\hline cut6 & & & 1.0421 & \\
\hline $\mathrm{N}$ & 46,034 & 46,168 & 23,911 & 38,256 \\
\hline Pseudo $\mathrm{R}^{2}$ & .0451 & .0507 & .0403 & .752 \\
\hline Age minimum & 42 & 26 & 43 & 77 \\
\hline \multicolumn{5}{|c|}{$\begin{array}{l}\text { Source: GSS 2006. All equations also include } 9 \text { birth cohort decadal dummies and } 8 \text { region dummies. } \\
\text { HAPPY: Taken all together, how would you say things are these days - would you say that you are very happy, } \\
\text { pretty happy, or not too happy? (Coded } 3,2,1 \text {, respectively). } \\
\text { SATFIN: We are interested in how people are getting along financially these days. So far as you and your family are } \\
\text { concerned, would you say that you are pretty well satisfied with your present financial situation, more or less } \\
\text { satisfied, or not satisfied at all? (Coded } 3,2,1 \text { respectively). } \\
\text { SATFAM: For each area of life I am going to name, tell me the number that shows how much satisfaction you get } \\
\text { from that area. Your family life } 1 \text {. A very great deal } 2 \text {. A great deal } 3 \text {. Quite a bit } 4 \text {. A fair amount } 5 \text {. Some } 6 \text {. A } \\
\text { little 7. None (Reverse coded here) } \\
\text { HEALTH: would you say in general your health is excellent, good, fair or poor }\end{array}$} \\
\hline
\end{tabular}


Table 12a. Happiness equations, Asia: 2003-2004.

\begin{tabular}{|c|c|c|c|}
\hline & (1) & (2) & (3) \\
\hline & 2003 & 2004 & 2003-2004 \\
\hline Age & $-.0609(3.64)$ & $-.0530(3.51)$ & $-.0545(4.89)$ \\
\hline $\mathrm{Age}^{2}$ & $.0006(2.94)$ & $.0006(3.38)$ & $.0005(4.25)$ \\
\hline Male & $.1131(2.34)$ & $.0055(0.12)$ & $.0556(1.96)$ \\
\hline 2004 & & & $.0974(2.06)$ \\
\hline Married & $.5337(8.21)$ & $.3379(5.56)$ & $.4297(9.72)$ \\
\hline Divorced/separated & $-.7679(5.31)$ & $-.4338(3.11)$ & $-.5873(5.88)$ \\
\hline Widowed & $-.3372(2.13)$ & $-.3545(2.46)$ & $-.3298(3.13)$ \\
\hline Elementary school & $-.2265(1.53)$ & $.1359(1.14)$ & $-.0271(0.29)$ \\
\hline High school & $-.1977(1.35)$ & $.2888(2.35)$ & $.0487(0.52)$ \\
\hline Vocational school & $.1407(0.89)$ & $.2014(1.25)$ & $.2784(2.56)$ \\
\hline Professional school & $-.0057(0.04)$ & $.4041(2.92)$ & $.1959(1.92)$ \\
\hline University & $-.0763(0.50)$ & $.4324(3.22)$ & $.1735(1.74)$ \\
\hline Business owner mining & $-.2329(1.03)$ & $.0195(0.08)$ & $-.0839(0.57)$ \\
\hline Business owner retail & $-.0436(0.22)$ & $.1060(0.76)$ & $.0880(0.84)$ \\
\hline Vendor/street trader & $-.3903(2.14)$ & $-.0467(0.38)$ & $-.2284(2.51)$ \\
\hline Business owner $>30 \mathrm{wkrs}$ & $.0765(0.27)$ & $.1698(0.52)$ & $.2185(1.08)$ \\
\hline Self-employed profsnl & $-.1191(0.52)$ & $-.0972(0.47)$ & $-.0453(0.32)$ \\
\hline Senior manager & $.1003(0.42)$ & $.3179(1.38)$ & $.2387(1.56)$ \\
\hline Employed professional & $-.3691(1.90)$ & $.1311(1.03)$ & $-.0526(0.52)$ \\
\hline Clerical & $-.1217(0.68)$ & $.0468(0.44)$ & $-.0016(0.02)$ \\
\hline Sales & $-.1244(0.66)$ & $-.0897(0.82)$ & $-.0678(0.75)$ \\
\hline Manual & $-.4373(2.54)$ & $-.1523(1.62)$ & $-.2525(3.18)$ \\
\hline Driver & $-.3220(1.52)$ & $-.1068(0.73)$ & $-.2073(1.81)$ \\
\hline Other worker & $-.2107(1.10)$ & $.0259(0.26)$ & $-.0708(0.81)$ \\
\hline Homemaker & $-.1748(0.99)$ & $.0829(0.86)$ & $.0332(0.42)$ \\
\hline Student & $-.0042(0.02)$ & $-.0244(0.18)$ & $.0371(0.36)$ \\
\hline Retired & $-.3681(1.73)$ & $.3568(1.83)$ & $-.0487(0.38)$ \\
\hline Unemployed & $-.3312(1.77)$ & $-.3040(2.53)$ & $-.2613(2.77)$ \\
\hline Brunei & $2.0931(20.87)$ & & $1.8634(22.63)$ \\
\hline Cambodia & $-1.1444(11.56)$ & & $-1.2613(16.21)$ \\
\hline China & & $.1355(1.75)$ & $.1703(2.27)$ \\
\hline Indonesia & $.7814(7.88)$ & & $.4968(6.32)$ \\
\hline Korea & $-.4566(6.02)$ & $-.5237(5.49)$ & $-.5538(9.67)$ \\
\hline Laos & $.1558(1.58)$ & & $-.0544(0.69)$ \\
\hline Malaysia & $.4374(5.53)$ & $1.1094(11.45)$ & $.7029(11.90)$ \\
\hline Myanmar & $.2563(3.18)$ & $.0389(0.38)$ & $.1005(1.65)$ \\
\hline Philippines & $.8101(8.06)$ & & $.6123(7.39)$ \\
\hline Singapore & $.9663(9.88)$ & & $.7894(9.86)$ \\
\hline Thailand & $.1916(2.35)$ & $.8087(8.00)$ & $.4205(6.89)$ \\
\hline Vietnam & $.3507(4.34)$ & $.8255(8.04)$ & $.5075(8.22)$ \\
\hline cut1 & -5.2402 & -4.9904 & -5.0458 \\
\hline cut2 & -3.2705 & -2.7417 & -2.9530 \\
\hline cut3 & -1.7456 & -.9109 & -1.2860 \\
\hline cut4 & .4602 & 1.4327 & .9750 \\
\hline $\mathrm{N}$ & 8,063 & 9,656 & 17,719 \\
\hline Pseudo $\mathrm{R}^{2}$ & .0187 & .0754 & .0459 \\
\hline
\end{tabular}

Source: Asianbarometers, 2003/4. Notes: excluded categories, Japan; single; self-employed in agriculture; no formal education. 
Table 12b. Five-step life satisfaction in Asia and Europe, ordered logits

\begin{tabular}{|c|c|c|c|}
\hline & All & Asia & Europe \\
\hline Age & $-.0389(6.05)$ & $-.0202(2.19)$ & $-.0582(6.45)$ \\
\hline $\mathrm{Age}^{2}$ & $.0004(6.59)$ & $.0003(2.97)$ & $.0006(6.39)$ \\
\hline Male & $.0050(0.14)$ & $-.0602(1.35)$ & $.0446(1.04)$ \\
\hline Years of Education & $.0144(3.96)$ & $.0107(1.71)$ & $.0173(3.90)$ \\
\hline Part-time $15-34 \mathrm{hrs}$ & $-.1321(2.54)$ & $-.0856(1.20)$ & $-.1748(2.28)$ \\
\hline Part-time $<15 \mathrm{hrs}$ & $-.3989(4.23)$ & $-.3739(3.07)$ & $-.4217(2.82)$ \\
\hline Unemployed & $-.8698(12.25)$ & $-.6509(6.23)$ & $-1.0340(10.60)$ \\
\hline Retired & $.0185(0.31)$ & $.1725(1.85)$ & $-.0375(0.45)$ \\
\hline Student & $.0665(1.03)$ & $.0246(0.26)$ & $.1135(1.28)$ \\
\hline Disabled & $-.8076(6.27)$ & $-.2873(1.17)$ & $-.9950(6.50)$ \\
\hline Home worker & $.0225(0.47)$ & $.1144(1.80)$ & $-.1279(1,75)$ \\
\hline China & $-.6128(5.80)$ & $.0222(0.24)$ & \\
\hline Indonesia & $-.9945(9.50)$ & $-.3335(3.77)$ & \\
\hline Japan & $-1.0882(10.58)$ & $-.4530(4.98)$ & \\
\hline Malaysia & $.5612(5.60)$ & $1.2387(13.80)$ & \\
\hline Philippines & $-.6495(6.09)$ & & \\
\hline Singapore & $.4854(5.32)$ & $1.1575(12.46)$ & \\
\hline South Korea & $-1.1532(11.14)$ & $-.4814(5.43)$ & \\
\hline Taiwan & $-.8515(8.25)$ & $-.2023(2.29)$ & \\
\hline Thailand & $.0830(0.79)$ & $.7481(8.35)$ & \\
\hline France & $-.1068(1.02)$ & & $-.0552(0.46)$ \\
\hline Germany & $.2187(2.13)$ & & $.2779(2.33)$ \\
\hline Greece & $-.6369(6.27)$ & & $-.5683(4.90)$ \\
\hline Ireland & $-.0280(0.34)$ & & $-.0226(0.27)$ \\
\hline Italy & $-.1751(1.67)$ & & $-.0999(0.82)$ \\
\hline Portugal & $-.8867(8.76)$ & & $-.8485(7.24)$ \\
\hline Spain & $.1017(0.97)$ & & $.1885(1.56)$ \\
\hline Sweden & $.7458(7.53)$ & & .7707 (6.96) \\
\hline Living with spouse & $.2354(6.00)$ & $.0429(0.78)$ & $.4417(7.72)$ \\
\hline Living with children & $.0440(1.28)$ & $.0685(1.36)$ & $.0325(0.67)$ \\
\hline Living alone & $-.2406(4.38)$ & $-.1437(1.44)$ & $-.1417(2.02)$ \\
\hline No English & $-.2741(4.38)$ & $-.2748(5.18)$ & $-.3007(5.54)$ \\
\hline English native speaker & $.1855(2.79)$ & $.1615(1.66)$ & $.2377(2.59)$ \\
\hline /cut1 & -4.0738 & -3.1443 & -4.3091 \\
\hline /cut2 & -2.5235 & -1.5143 & -2.8690 \\
\hline /cut3 & -.7316 & .1917 & -.9634 \\
\hline /cut4 & 1.2928 & 2.3497 & .9668 \\
\hline $\mathrm{N}$ & 18,148 & 9,126 & 9,022 \\
\hline Pseudo $\mathrm{R}^{2}$ & .0470 & .0501 & .0402 \\
\hline
\end{tabular}

Source: Asia/Europe Survey (ASES): A multinational comparative study in eighteen countries, 2001. ICPSR \#22324.

Notes: excluded categories: United Kingdom in columns 1 and 3 and Philippines in column 2; and full-time worker. T-statistics in parentheses 
Table 13. Unhappiness equations, 2001-2006 (ordered logits).

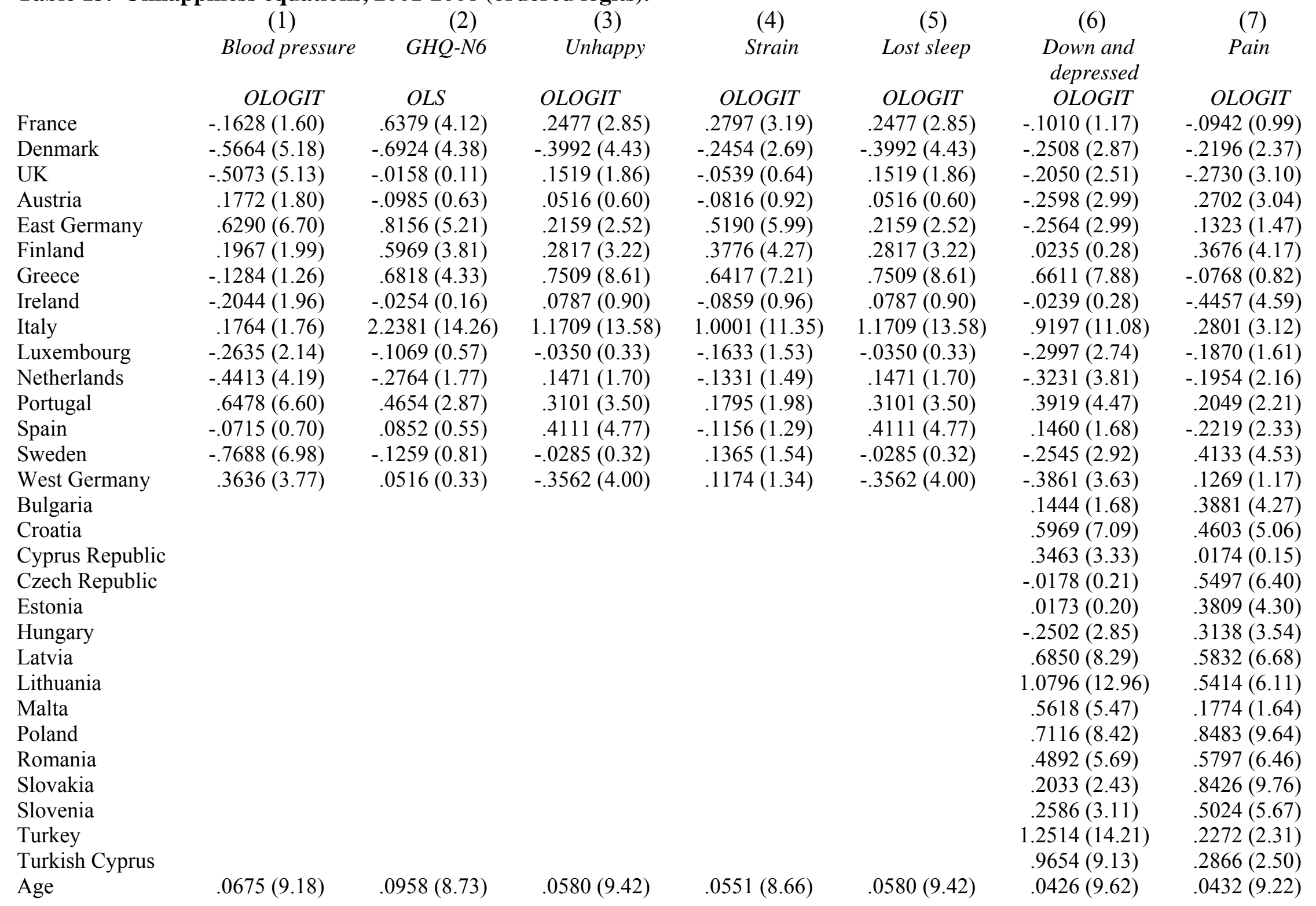




\begin{tabular}{|c|c|c|c|c|c|c|c|}
\hline $\mathrm{Age}^{2}$ & $-.00035(4.89)$ & $-.0010(9.22)$ & $-.0006(9.17)$ & $-.0006(9.75)$ & $-.0005(9.17)$ & $-.00037(8.28)$ & $-.00014(2.96$ \\
\hline Male & $.0222(0.55)$ & $-.4727(7.73)$ & $-.3122(9.20)$ & $-.1338(3.91)$ & $-.3122(9.20)$ & $-.3316(13.33)$ & $-.3302(12.44$ \\
\hline Age left schooling & $-.0173(3.53)$ & $-.0211(2.77)$ & $-.0022(0.53)$ & $-.0044(1.03)$ & $-.0022(0.53)$ & $-.0241(7.82)$ & $-.0388(11.88$ \\
\hline Constant/cut 1 & 2.6653 & 1.4913 & .6249 & .8070 & .6249 & .1346 & 1.0880 \\
\hline cut 2 & 4.2449 & 2.5083 & 2.6542 & 2.5083 & 1.0063 & 1.5043 & 2.1977 \\
\hline cut 3 & 5.8586 & 4.1751 & 4.4382 & 4.1751 & 2.6996 & 3.1742 & 3.1486 \\
\hline cut 4 & 4.4722 & & & & & 4.9244 & 4.63040 \\
\hline Pseudo/Adjusted $\mathrm{R}^{2}$ & .0847 & .1349 & .0487 & .0449 & .0487 & .0439 & .0826 \\
\hline $\mathrm{N}$ & 15,396 & 15,379 & 15,658 & 15,633 & 15,658 & 28,185 & 28,151 \\
\hline Age maximum & 96 & 48 & 48 & 46 & 58 & 58 & 160 \\
\hline
\end{tabular}

Notes: The dependent variable in column 1 is a measure of reported problems of high blood-pressure. The question that forms the dependent variable is, "Would you say that you have not at all, no more than usual, rather more than usual, much more than usual...had problems of high blood pressure?" where 1=not at all; $2=$ no more than usual; $3=$ rather more than usual; $4=$ much more than usual. The dependent variable in column 2 is a psychological distress score measured on a scale from 0 to 18. A GHQ-N6 score amalgamates answers to six questions: Have you recently: Lost much sleep over worry? Felt constantly under strain? Felt you could not overcome your difficulties? Been feeling unhappy and depressed? Been losing confidence in yourself? Been thinking of yourself as a worthless person? Its mean in the sample is 3.6 (s.d. =3.7). The dependent variable in columns 3-5 are in order a) column $3=$ 'Would you say that you have not at all, no more than usual, rather more than usual, much more than usual...been feeling unhappy and depressed?' b) column $4=$ 'Would you say that you have not at all, no more than usual, rather more than usual, much more than usual... been feeling constantly under strain?' c) column $5=$ 'Would you say that you have not at all, no more than usual, rather more than usual, much more than usual.. 'Would you say that you have not at all, no more than usual, rather more than usual, much more than usual... 'lost much sleep over worry?'

Personal controls are also included in columns 1-5 are 10 dummy variables relating to the individual's experiences before the age of 18 ; 16 labour-force status dummies; and 8 marital-status dummies. Belgium is the excluded nation.

The dependent variable in Column 6 models the following question 'These questions are about how you feel and how things have been with you during the past 4 weeks. For each question, please give the one answer that comes closest to the way you have been feeling...How much of the time during the past 4 weeks have you felt downhearted and depressed? All the time, most of the time, sometimes, rarely, never. In column 7 the question is 'During the past four weeks how much if at all, has pain interfered with your activities? Extremely, quite a lot, moderately, a little and not at all? In empirical estimation we reversed the ordering.

Personal controls included in columns 6 and 7 are 16 labour-force status dummies; and 8 marital-status dummies. Belgium is the excluded nation. T-statistics are in parentheses.

Source: columns 1-5: Eurobarometer \#56.1: Social Exclusion and Modernization of Pension Systems, September-October 2001, ICPSR \#3475 and Blanchflower and Oswald (2008a): Column 6 Eurobarometer 64.4: Mental Well-Being, Telecommunications, Harmful Internet Content, and Farm Animal Welfare, December 2005-January 2006, ICPSR \#4667 
Table 14. Happiness and Unhappiness Equations, European Social Survey 2006/7 (ordered logits).

(1)

Life satisfaction Happiness

(3)

(4)

Age

$\mathrm{Age}^{2}$

Male

Bulgaria

Denmark

Estonia

Finland

France

Germany

Great Britain

Hungary

Norway

Poland

Portugal

Romania

Russia

Slovakia

Slovenia

Spain

Sweden

Switzerland

Primary

Lower secondary

Upper secondary

Non-tertiary

$1^{\text {st }}$ stage tertiary

$2^{\text {nd }}$ stage tertiary

Married

Civil partner

Separated

$\begin{array}{llll}.0006(17.77) & -.0757(19.98) & -.0681(18.05) & .0144(3.33)\end{array}$

$\begin{array}{llll}.0006(17.77) & .0007(18.86) & .0007(19.79) & -.0001(4.40) \\ -.0900(4.51) & -.1396(6.94) & .0133(0.67) & -.3881(16.32)\end{array}$

$\begin{array}{llll}-1.8246(26.25) & -1.8829(26.66) & -2.7447(38.91) & .2715(3.39)\end{array}$

$\begin{array}{llll}1.2081(18.03) & .8112(12.22) & .9930(14.62) & -.8543(9.84)\end{array}$

$\begin{array}{lllll}-.5613(8.41) & -.5132(7.66) & -1.2267(18.23) & .1649(2.16)\end{array}$

$.7498(12.06) \quad .5886(9.46) \quad .1653(2.63)-1.1273(13.82)$

$\begin{array}{llll}-.6308(10.07) & -.2637(4.28) & -.6065(9.78) & -.1376(1.88)\end{array}$

$\begin{array}{llll}-.3417(5.80) & -.3654(6.22) & -.4580(7.70) & -.0690(1.00)\end{array}$

$\begin{array}{lllll}-.0972(1.61) & .0187(0.31) & -.0795(1.30) & -.2742(3.78) & -.07\end{array}$

$\begin{array}{llll}-1.1962(17.76) & -.7658(11.09) & -1.2413(18.31) & 1.1965(15.90)\end{array}$

$\begin{array}{llll}.3543(5.57) & .3362(5.27) & .2900(4.52) & -.7612(9.36)\end{array}$

$\begin{array}{llll}-.3125(4.72) & -.4102(6.22) & -1.0352(15.76) & .3509(4.68)\end{array}$

$\begin{array}{llll}-1.1116(17.94) & -.7288(11.76) & -.9754(15.79) & .1535(2.15)\end{array}$

$\begin{array}{llll}-.4946(7.40) & -.6367(9.52) & -.9658(14.52) & -.7713(9.95)\end{array}$

$-1.3802(22.47)-1.2003(19.42)-2.3763(37.78) \quad .3083(4.36)$

$-.9316(14.15) \quad-.9521(14.41)-1.0570(15.98) \quad .3217(4.23)$

$\begin{array}{llll}-.0498(0.74) & -.0513(0.76) & -.5968(8.86) & -.4390(5.51)\end{array}$

$\begin{array}{llll}.3175(5.02) & .2956(4.65) & -.1610(2.54) & -.2762(3.69)\end{array}$

$\begin{array}{llll}.5252(8.35) & .3757(5.99) & .3889(6.10) & -.6693(8.52)\end{array}$

$\begin{array}{llll}.6907(10.77) & .5006(7.87) & .4709(7.28) & -.0641(0.85)\end{array}$

$.2376(3.89) \quad .3142(5.06)$

$.3300(5.37) \quad .3879(6.21)$

$.4452(7.20) \quad .4967(7.91)$

$.5597(8.16) \quad .5880(8.47)$

$5781(9.13)$

$5610(8.73)$

$.2698(4.39)$

$.4361(7.06)$

$.5728(9.21)$

$.6731(9.77)$

$-.2885(4.27)$

$-.4830(7.04)$

$-.6224(8.97)$

$-.6502(8.38)$

$.8667(13.59) \quad-.6736(9.42)$

$.7583(8.33)$

$.4380(14.44)$

$.8046(8.73)$

$1.1244(12.36) \quad-.8300(7.67)$

$.4855(15.92) \quad-.2097(5.79)$

$1576(2.32)$

$.1816(2.68)$

$-.1814(2.22)$

$-.5256(5.96)$
(5)

Lonely

$.0127(2.88)$

$-.0001(2.91)$

$-.1367(5.49)$

$.5862(7.00)$

$-.7340(7.68)$

$.1317(1.59)$

$-1.4849(20.38)$

$.2460(3.16) \quad-.3743(5.48)$

$-.1783(2.35) \quad-2.3118(31.74)$

$-.0736(0.95) \quad-.8920(13.19)$

$.3155(3.84) \quad-.0889(1.21)$

$-.4393(5.08) \quad-2.2072(26.72)$

$.0381(0.46) \quad-.8912(12.15)$

$.5163(6.79) \quad-.3686(5.38)$

$.2046(2.56) \quad-.3411(4.74)$

$.7754(10.44) \quad .1851(2.77)$

$.7914(9.94) \quad-.5862(8.05)$

$.0248(0.30) \quad-1.3731(17.94)$

$-.1086(1.34)-1.6832(22.57)$

$-.2806(3.39) \quad-1.1832(16.49)$

$-.3779(4.42) \quad-.2113(3.01)$

$-.2050(2.99) \quad-.1396(2.03)$

$-.4047(5.81) \quad-.2502(3.60)$

$-.5085(7.21) \quad-.3773(5.38)$

$-.4655(5.88) \quad-.3994(5.13)$

$-.5457(7.46) \quad-.3842(5.33)$

$-.8173(7.02) \quad-.3794(3.64)$

$-.9238(24.54) \quad-.0283(0.79)$

$-.4824(5.70) \quad .0722(0.92)$

$.5793(6.02) \quad .5072(5.23)$ 


\begin{tabular}{|c|c|c|c|c|c|c|}
\hline Separated civil & $-.4096(1.75)$ & $-.5080(2.04)$ & $-.5818(2.46)$ & $.0237(0.09)$ & $.0299(0.11)$ & $-.3953(1.37)$ \\
\hline Divorced & $-.0341(0.78)$ & $.0680(1.54)$ & $-.1768(4.01)$ & $.0591(1.15)$ & $.1415(2.78)$ & $.1090(2.14)$ \\
\hline Widowed & $-.1442(3.09)$ & $-.2350(4.98)$ & $-.1357(2.90)$ & $.2502(4.68)$ & $6951(12.91)$ & $.3614(6.78)$ \\
\hline Dissolved civil & $-.3086(2.31)$ & $-.2289(1.66)$ & $-.6762(4.90)$ & $.4097(2.60)$ & $.4304(2.86)$ & $.6273(4.02)$ \\
\hline Student & $.1985(4.45)$ & $.1130(2.53)$ & $.2913(6.40)$ & $-.0716(1.33)$ & $-.1473(2.72)$ & $.0039(0.08)$ \\
\hline Unemployed & $-.9607(16.42)$ & $-.6475(11.10)$ & $1.0584(18.32)$ & $.5804(9.17)$ & $.4485(6.96)$ & $.4314(6.70)$ \\
\hline Unemployed ntlk & $-.7776(9.97)$ & $-.5443(6.88)$ & $-.8716(11.03)$ & $.4712(5.41)$ & $.5392(6.19)$ & $.4546(5.20)$ \\
\hline Disabled & $-.5285(8.08)$ & $-.4053(5.96)$ & $-.5751(8.56)$ & $.8379(11.64)$ & $.5534(7.53)$ & $.6312(8.67)$ \\
\hline Retired & $.0896(2.44)$ & $.0587(1.59)$ & $-.1088(2.97)$ & $.0927(2.19)$ & $.0915(2.05)$ & $.1516(3.60)$ \\
\hline Military service & $-.2866(0.96)$ & $-.5011(1.53)$ & $-.6952(2.16)$ & $.5182(1.39)$ & $.1838(0.45)$ & $.8609(2.29)$ \\
\hline Home worker & $-.0085(0.22)$ & $.0031(0.08)$ & $-.0797(2.09)$ & $.1112(2.57)$ & $.2229(4.80)$ & $.0792(1.83)$ \\
\hline Other lf & $-.0747(0.76)$ & $.0461(0.47)$ & $-.0302(0.31)$ & $.4364(4.07)$ & $.3025(2.76)$ & $.2826(2.63)$ \\
\hline Health bad & $.4034(5.36)$ & $.4580(5.92)$ & $.3564(4.74)$ & $-.5158(6.54)$ & $-.2409(3.09)$ & $-.2997(3.75)$ \\
\hline Health fair & $.8716(12.01)$ & $.9745(13.05)$ & $.8008(11.06)$ & $-1.0676(14.02)$ & $-.6548(8.72)$ & $-.7573(9.85)$ \\
\hline Health good & $1.4213(19.28)$ & $1.5147(20.00)$ & $1.2440(16.95)$ & $-1.6578(21.35)$ & $-.9363(12.25)$ & $-1.2391(15.85)$ \\
\hline Health very good & $1.9183(24.98)$ & $2.0326(25.82)$ & $1.6860(22.05)$ & $-2.1002(25.47)$ & $-1.2024(14.76)$ & $-1.5664(19.04)$ \\
\hline cut1 & -4.2391 & -5.2394 & -4.4362 & -1.7911 & -.6224 & -2.1631 \\
\hline cut2 & -3.6320 & -4.5336 & -3.8224 & .5269 & 1.2865 & .2997 \\
\hline cut3 & -3.0043 & -3.7943 & -3.1211 & 2.0986 & 2.5759 & 1.9788 \\
\hline cut4 & -2.3563 & -3.0901 & -2.4627 & & & \\
\hline cut5 & -1.8710 & -2.5543 & -1.9433 & & & \\
\hline cut6 & -.9569 & -1.4430 & -1.0441 & & & \\
\hline cut7 & -.4357 & -.8456 & -.4025 & & & \\
\hline cut8 & .4154 & .1110 & -.5434 & & & \\
\hline cut9 & 1.7241 & 1.4642 & 1.9403 & & & \\
\hline cut10 & 2.8699 & 2.6767 & 3.1896 & & & \\
\hline Pseudo $\mathrm{R}^{2}$ & .0767 & .0711 & .0885 & .0961 & .0941 & .1160 \\
\hline $\mathrm{N}$ & 34,786 & 34,638 & 34,780 & 34,592 & 34,674 & 34,643 \\
\hline Age $\min / \max$ & 49 & 53 & 46 & 39 & 50 & 33 \\
\hline
\end{tabular}

Source: European Social Survey, 2006/7. Notes; Excluded categories: Belgium; single; health very bad; paid work and no formal education. A) All things considered, how satisfied are you with your life as a whole nowadays? B) And how satisfied are you with your present standard of living? Please answer using this card, where 0 means extremely dissatisfied and 10 means extremely satisfied. Taking all things together, how happy would you say you are? Extremely unhappy $=0$ to Extremely happy=10. Using this card, please tell me how much of the time during the past week 1) you felt depressed? 2) you felt lonely? 3) you felt anxious? A) None or almost none of the time. B) Some of the time. D) Most of the time. D) All or almost all of the time. 
Table 15. Macro Life satisfaction, 1973-2006 (ordered logits).

Life satisfaction $\mathrm{t}_{\mathrm{t}-1}$

$\begin{array}{lll}\text { Inflation }_{\mathrm{t}} & -.0056(3.87) & -.0029(2.32) \\ \text { Unemployment }_{\mathrm{t}} & -.0126(6.26) & -.0046(2.77)\end{array}$

$\mathrm{GDP}_{\mathrm{t}}$

Austria

Belgium

Czech Republic

Denmark

Finland

France

Germany

Greece

Hungary

Ireland

Italy

Japan

Luxembourg

Mexico

Netherlands

Poland

Portugal

Slovakia

Spain

Sweden

USA

Constant

Adjusted $\mathrm{R}^{2}$

$\mathrm{N}$
(1)

(2)

$.5713(13.83)$

$-.0458(2.24)$

$-.0181(1.26)$

$-.1284(4.18)$

$.1710(7.94)$

.0248 (1.21)

$-.1253(6.64)$

-.0563 (3.65)

$-.1937(7.31)$

$-.2768(7.30)$

$.0329(2.10)$

-.1375 (6.77)

$-.2317(8.27)$

.0475 (2.71)

$-.2517(4.32)$

.0792 (4.68)

$-.2705(6.53)$

.1835 (9.50)

$-.2952(6.80)$

$-.1135(2.97)$

$-.5259(24.67) \quad-.2211(8.11)$

$-.4588(10.64) \quad-.1769(4.34)$

$-.1276(5.30)$

$.1590(6.03)$

$.1674(5.64)$

3.1310

$-.0528(2.69)$

$.0736(3.36)$

$.1137(4.02)$

1.4209
(3)

$-.0061(4.11)$
$-.0119(5.69)$
$.000002(1.46)$
$-.0783(3.04)$

$-.0783(3.04)$

$-.0250(1.36)$

$-.2737(5.59)$

.3707 (18.67)

$.0493(1.90)$

$-.2920(15.85)$

$-.1333(7.16)$

$-.4474(16.05)$

$-.5785(11.73)$

$.0847(4.11)$

$-.3346(17.06)$

$-.5519(19.79)$

$.0497(1.71)$

$-.2167(3.89)$

$.1844(9.53)$

$-.2511(4.76)$

$-.4917(15.47)$

$-.4112(7.63)$

$-.1075(3.89)$

$.1544(5.81)$

.1465 (4.46)

3.2277

.9376
455
(4)

.5689 (13.64)

$-.0031(2.37)$

$-.0046(2.63)$

$.00001(0.51)$

$-.0452(2.19)$

$-.0178(1.22)$

$-.1175(2.81)$

.1688 (7.64)

$.0252(1.22)$

$-.1253(6.61)$

$-.0566(3.66)$

$-.1876(6.41)$

$-.2640(5.73)$

$.0360(2.17)$

$-.1354(6.50)$

$-.2403(7.45)$

.0395 (1.71)

$-.2371(3.63)$

.0799 (4.60)

$-.1014(2.27)$

$-.2130(6.64)$

$-.1641(3.45)$

$-.0472(2.10)$

$.0726(3.29)$

.1081 (3.56)

1.4230

.9630

Notes: UK is excluded category. T-statistics in parentheses. Equations also include 31 year dummies. GDP is per capita in \$US. Data on GDP unavailable in 2006 for Czech Republic and Ireland.

Source: World Database of Happiness and OECD, 1973-2006. 
Table 16: Micro life satisfaction: Europe, 1973-2006 (ordered logits).

(1)

$\begin{array}{ll}\text { Inflation }_{\mathrm{t}} & -.0094(5.16) \\ \text { Unemployment rate }_{\mathrm{t}} & -.0114(5.82) \\ \text { Average inflation experience } & \\ \text { Highest inflation experience } & \\ \text { Age } & -.0133(16.42) \\ \text { Age }^{2} & .0001(18.68) \\ \text { Male } & -.0327(10.48) \\ \text { 16-19 yrs schooling } & .0873(17.72) \\ \text { 20+ yrs schooling } & .1664(26.12) \\ \text { Still studying } & .1178(7.88) \\ \text { Married } & .1186(19.86) \\ \text { Living as married } & .0481(7.38) \\ \text { Divorced } & -.1621(20.04) \\ \text { Separated } & -.2065(19.13) \\ \text { Widowed } & -.0866(13.17) \\ \text { Self-employed } & .0057(1.22) \\ \text { Home } & -.0243(4.80) \\ \text { Student } & .0710(4.90) \\ \text { Retired } & -.0395(6.88) \\ \text { Unemployed } & -.3657(29.77) \\ \text { Austria } & -.0956(4.17) \\ \text { Belgium } & -.0807(0.23) \\ \text { Denmark } & .3220(21.96) \\ \text { Finland } & -.0001(0.00) \\ \text { France } & -.3271(23.35) \\ \text { Germany } & -.2286(19.35) \\ \text { Greece } & -.4596(20.71) \\ & \\ & \end{array}$

(3)

$-.0096(5.25)$
$-.0119(6.05)$
$-.0010(1.02)$
$-.0001(3.44)$
$-.0134(16.74)$
$.0001(19.11)$
$-.0329(10.51)$
$.0871(17.80)$
$.1664(26.23)$
$.1174(7.82)$
$.1189(19.92)$
$.0496(7.61)$
$-.1622(20.05)$
$-.2061(19.12)$
$-.0852(12.95)$
$.0056(1.19)$
$-.0244(4.81)$
$.0715(4.93)$
$-.0395(6.89)$
$-.3660(29.71)$
$-.0904(3.96)$
$-.0807(4.39)$
$.3206(21.78)$
$.0032(0.16)$
$-.3254(22.99)$
$-.2229(18.85)$
$-.4485(20.32)$

(4)

Age $<40$
$-.0102(4.83)$
$-.0109(5.71)$

$-.0002(2.62)$
$-.0067(1.87)$
$-.0000(0.01)$
$-.0424(11.94)$
$.0723(10.70)$
$.1530(21.10)$
$.1127(9.02)$
$.1325(20.30)$
$.0569(8.20)$
$-.1693(15.76)$
$-.2085(13.83)$
$-.0938(3.35)$
$.0295(4.69)$
$-.0293(4.50)$
$.0589(4.94)$
$-.1463(6.23)$
$-.3574(30.25)$
$-.0720(2.65)$
$-.0432(2.11)$
$.3515(21.58)$
$.0397(1.60)$
$-.3044(17.94)$
$-.2255(17.82)$
$-.3443(15.86)$

(5)

Age $\geq 40$ $-.0128(5.89)$ $-.0081(4.20)$

$-.00003(2.85)$

$-.0048(3.83)$

.00007 (7.41)

$-.0230(5.69)$

$.0931(18.85)$

$.1666(21.92)$

$-.0080(0.11)$

.1275 (17.81)

.0406 (3.65)

$-.1415(14.86)$

$-.1839(12.83)$

$-.0723(9.77)$

$-.0097(1.71)$

$-.0205(3.43)$

.0487 (0.73)

$-.0348(5.96)$

-.3909 (24.68)

$-.1142(4.90)$

$-.1164(5.99)$

.2969 (19.72)

$-.0283(1.49)$

-.3440 (25.36)

$-.2289(17.34)$

$-.5500(20.14)$ 


$\begin{array}{lccccc}\text { Ireland } & .0524(3.50) & .0540(3.61) & .0549(3.68) & .0471(2.83) & .0651(4.01) \\ \text { Italy } & -.3434(17.47) & -.3374(15.85) & -.3306(16.34) & -.2789(12.53) & -.3850(20.09) \\ \text { Netherlands } & .1199(10.55) & .1179(10.12) & .1181(10.33) & .1549(11.70) & .0869(7.23) \\ \text { Norway } & .1072(3.47) & .1064(3.44) & .1057(3.42) & .1423(4.65) & .0757(2.30) \\ \text { Portugal } & -.4979(21.41) & -.4939(21.13) & -.4973(21.47) & -.3746(15.68) & -.6047(25.23) \\ \text { Spain } & -.1240(7.41) & -.1206(7.10) & -.1200(7.14) & -.0794(3.98) & -.1632(9.79) \\ \text { Sweden } & .1057(8.12) & .1054(8.07) & .1054(8.04) & .1386(7.04) & .0821(6.27) \\ \text { Constant } & 3.5198 & 3.5262 & 3.5264 & 3.4315 & 3.2963 \\ & & & & 332.202 & 370,970 \\ \mathrm{~N} & 703,172 & 703,172 & 703,172 & .1581 & .1639\end{array}$

Notes: excluded categories UK, employee, no children: left school before age 15; single. All equations include 20 year dummies. Standard errors are clustered by country and year. Average inflation experience refers to the average annual inflation rate experienced by an individual over their life to the survey date. Highest inflation experienced refers to the highest annual inflation rate experienced by an individual over their life to the survey date.

Source: Eurobarometers, 1973-2006 and Blanchflower (2007) 
Table 17. Happiness, life satisfaction and views on the macro economy ordered logits, 2006-2007

\begin{tabular}{|c|c|c|c|}
\hline & Happiness & Life satisfaction & Life satisfact \\
\hline Inequality - current & $-.1976(5.77)$ & & \\
\hline Unemployment - current & $-.0787(2.71)$ & $-.0745(2.79)$ & \\
\hline Inflation - current & $-.2313(8.40)$ & $-.1468(4.83)$ & \\
\hline Inflation equal & & & $-.0409(0.97)$ \\
\hline Inflation higher & & & $-.0671(1.83)$ \\
\hline Unemployment equal & & & $-.1895(4.80)$ \\
\hline Unemployment higher & & & $-.2402(6.56)$ \\
\hline Age & $-.0973(19.20)$ & $-.0785(16.84)$ & $-.0871(14.48)$ \\
\hline $\mathrm{Age}^{2}$ & $.0008(16.43)$ & $.0007(15.99)$ & $.0008(13.65)$ \\
\hline Male & $-.1655(6.00)$ & $-.1187(4.60)$ & $-.0566(1.83)$ \\
\hline ALS $<16$ & $-.0958(0.66)$ & $.3097(2.84)$ & $-.3417(0.82)$ \\
\hline ALS 16-19 & $.1883(1.30)$ & $.6316(5.72)$ & $-.2154(0.52)$ \\
\hline$A L S \geq 20$ & $.3747(2.55)$ & $.8830(7.87)$ & $.0368(0.09)$ \\
\hline Unemployed & $-.7356(10.43)$ & $-.6970(11.01)$ & $-.8683(10.77)$ \\
\hline Retired & $-.1756(3.11)$ & $.0142(0.27)$ & $-.1487(2.19)$ \\
\hline Married & $.8203(16.61)$ & $.3283(7.18)$ & $.3544(6.48)$ \\
\hline Remarried & $.6441(6.42)$ & $.2989(3.16)$ & $.3703(3.28)$ \\
\hline Living as married & $.4075(6.88)$ & $.1736(3.10)$ & $.1033(1.55)$ \\
\hline Previous lived together & $-.2089(2.69)$ & $-.2262(3.21)$ & $-.4206(5.10)$ \\
\hline Divorce & $-.1563(2.35)$ & $-.2834(4.50)$ & $-.4249(5.64)$ \\
\hline Separated & $-.5704(5.15)$ & $-.3983(3.71)$ & $-.4337(3.49)$ \\
\hline Widowed & $-.4460(6.80)$ & $-.2379(3.89)$ & $-.3670(4.85)$ \\
\hline Austria & $-.9599(10.46)$ & $.0404(0.55)$ & $-.0304(0.35)$ \\
\hline Bulgaria & $-3.1762(33.98)$ & $-2.2106(30.93)$ & $-2.2350(23.42)$ \\
\hline Cyprus & $-1.0438(9.06)$ & $.3658(3.74)$ & $.3694(2.77)$ \\
\hline Czech Republic & $-1.2175(13.65)$ & $-.3675(5.08)$ & $-.3712(4.40)$ \\
\hline Denmark & $.4515(4.90)$ & $1.9123(23.45)$ & $1.7403(18.61)$ \\
\hline East Germany & $-1.2621(11.05)$ & $-.5185(5.31)$ & $-.4315(3.97)$ \\
\hline
\end{tabular}




$\begin{array}{lccc}\text { Estonia } & -1.6008(17.00) & -.6161(8.28) & -.7205(7.96) \\ \text { Finland } & -.4786(5.31) & .7295(9.88) & .4965(5.88) \\ \text { France } & -.2727(3.00) & -.0309(0.42) & -.2405(2.65) \\ \text { Greece } & -1.2132(12.85) & -.6965(9.42) & -1.0286(12.59) \\ \text { Hungary } & -1.6718(17.61) & -1.5970(22.32) & -1.5296(17.90) \\ \text { Ireland } & .2515(2.73) & .8377(11.11) & .7815(8.75) \\ \text { Italy } & -1.1559(12.49) & -.3288(4.48) & -.6513(7.02) \\ \text { Latvia } & -1.7255(18.56) & -.9410(12.72) & -1.1391(13.10) \\ \text { Lithuania } & -1.8129(19.28) & -1.0639(14.30) & -1.0678(11.90) \\ \text { Luxembourg } & -.0565(0.51) & 1.1205(11.56) & 1.2979(10.77) \\ \text { Malta } & -.5982(5.19) & .2136(2.13) & .3762(2.96) \\ \text { Netherlands } & .0978(1.07) & 1.2924(16.78) & 1.1640(13.24) \\ \text { Poland } & -1.0093(10.85) & -.5752(7.84) & -.5261(5.64) \\ \text { Portugal } & -.9639(10.32) & -1.0027(13.87) & -1.0446(10.94) \\ \text { Romania } & -2.4141(25.56) & -1.7300(24.31) & -1.5874(15.49) \\ \text { Slovakia } & -1.8201(19.67) & -.8210(11.21) & -.8749(10.59) \\ \text { Slovenia } & -.6665(7.25) & .2936(4.04) & .1955(2.26) \\ \text { Spain } & -.6784(7.34) & .4474(6.07) & .0516(0.51) \\ \text { Sweden } & -.1260(1.38) & 1.2562(16.46) & 1.1273(12.91) \\ \text { UK } & .1592(1.84) & .7696(11.20) & .8118(9.32) \\ \text { West Germany } & -.8584(9.22) & .2374(3.21) & .3455(3.99) \\ \text { Member religious orgn. } & .2927(5.20) & .0455(1.17) & \\ \text { Minority group } & -.2695(5.78) & & \\ \text { No group } & -.1113(3.52) & & \\ \text { Own house - outright } & .2112(6.11) & .3899(12.65) & .2414(6.23) \\ \text { Own house - mortgage } & .1099(2.85) & .3356(9.33) & .3188(7.36) \\ \text { Left wing (1-2) } & .0478(0.75) & .0123(0.21) & .1210(1.67) \\ \text { Left (3-4) } & .0028(0.05) & .1584(3.17) & .2116(3.36) \\ \text { Centre (5-6) } & .0843(1.74) & .2392(5.35) & .2259(3.88) \\ \text { Right (7-8) } & .1413(2.60) & .3746(7.49) & .3792(5.98)\end{array}$




$\begin{array}{lccc}\text { Right wing (9-10) } & .3454(5.20) & .4856(8.31) & .5561(7.58) \\ & & & \\ \text { cut1 } & -7.1023 & -4.1532 & -5.6338 \\ \text { cut2 } & -4.8577 & -2.2430 & -3.6509 \\ \text { cut3 } & -1.4631 & .8395 & -.4712 \\ & & & \\ \mathrm{~N} & 26,526 & 29,017 & 20,472 \\ \text { Pseudo R } & .1319 & .1294 & .1297\end{array}$

Source: columns 1=Eurobarometer \#66.3 European Social Reality November-December 2006, (ICPSR \#4528). Column 2= Eurobarometer \#66.1 European values and societal issues, mobile phone use and farm animal welfare, Sept-Oct 2006 (ICPSR \#21281). Column 3 =Eurobarometer \#67.2 European Union enlargement, personal data privacy, national economy and scientific research, April-May 2007 (ICPSR\# 21160).

Notes: excluded categories; Belgium; responsible for ordinary shopping and housework; unmarried having previously lived with a partner; no formal education; refused to answer left/right scale and majority group. All equations also include 15 occupation dummies. T-statistics in parentheses.

Q1. On the whole, are you very satisfied, fairly satisfied, not very satisfied or not at all satisfied with the life you lead?

Q2. Do you think that, in (OUR COUNTRY), the inflation rate in 2006 was higher, lower or equal to the one in 2005 ?

Q3. Do you think that, in (OUR COUNTRY), the unemployment rate in 2006 was higher, lower or equal to the one in 2005?

Q4. Taking all things together would you say you are very happy, quite happy, not very happy and not at all happy?

Q5. Which topics worry you the most? - a) unemployment; b) the cost of living (inflation); c) the gap between the rich and the poor (inequality)?

Q6. In political matters people talk of "the left" and "the right". How would you place your views on this scale? 1 (Left) - 10 (Right) 
Table 18. Economic, Employment and Life Expectations in Europe: Eurobarometers, 1995-2006 (ordered logits).

\begin{tabular}{|c|c|c|c|c|c|c|c|c|}
\hline & \multicolumn{2}{|c|}{ Economic situation } & \multicolumn{2}{|c|}{ Employment situation } & \multicolumn{2}{|c|}{ Life 1 year ahead } & \multicolumn{2}{|c|}{ Life 5 years ahead } \\
\hline & (1) & (2) & (3) & (4) & $(5)$ & (6) & (7) & $(8)$ \\
\hline France & $-.1992(8.00)$ & $-.1645(5.65)$ & $.2112(8.41)$ & $.2532(8.65)$ & $.5166(20.17)$ & $.6714(22.18)$ & $.2419(7.76)$ & $.3045(8.99)$ \\
\hline Denmark & $.2793(11.31)$ & $.1640(5.68)$ & $.6710(26.70)$ & $.4432(15.09)$ & $.4741(18.48)$ & $.2439(8.01)$ & $.5509(17.42)$ & $.3427(9.88)$ \\
\hline UK & $.1664(7.23)$ & $.0751(2.80)$ & $.5437(23.41)$ & $.4223(15.64)$ & $.8461(35.52)$ & $.7944(28.28)$ & $.8284(28.01)$ & $.7599(23.68)$ \\
\hline Not very satisfied & & $.5787(22.91)$ & & $.5318(21.01)$ & & $.9013(34.32)$ & & $.8380(28.38)$ \\
\hline Fairly satisfied & & $1.0971(44.84)$ & & $.9678(39.53)$ & & $1.8423(72.14)$ & & $1.7548(61.65)$ \\
\hline Very satisfied & & $1.3750(52.90)$ & & $1.2523(48.21)$ & & $2.3265(85.19)$ & & $2.1457(69.87)$ \\
\hline Age & $-.0247(16.31)$ & $-.0177(10.33)$ & $-.0260(17.03)$ & $-.0187(10.89)$ & $-.0454(29.01)$ & $-.0338(18.99)$ & $-.0717(36.07)$ & $-.0623(29.09)$ \\
\hline $\mathrm{Age}^{2}$ & $.0002(12.98)$ & $.0001(7.84)$ & $.0002(13.53)$ & $.0001(8.30)$ & $.0002(14.87)$ & $.0001(6.75)$ & $.0004(19.36)$ & $.0002(13.11)$ \\
\hline Male & $.1379(15.73)$ & $.1347(13.62)$ & $.0694(7.86)$ & $.0791(7.96)$ & $-.0424(4.68)$ & $-.0443(4.30)$ & $-.0015(0.14)$ & $.0119(1.01)$ \\
\hline ALS 16-19 & $.1058(9.35)$ & $.0659(5.13)$ & $.1005(8.78)$ & $.0713(5.50)$ & $.2280(19.58)$ & $.1650(12.42)$ & $.1279(9.13)$ & $.0714(4.77)$ \\
\hline ALS $20+$ & $.2684(20.75)$ & $.1946(13.26)$ & $.2560(19.61)$ & $.1970(13.31)$ & $.4439(33.20)$ & $.3216(21.07)$ & $.3521(21.82)$ & $.2552(14.80)$ \\
\hline Still studying & $-.1670(2.25)$ & $-.1396(1.85)$ & $-.0469(0.63)$ & $-.0399(0.53)$ & $.0261(0.34)$ & $.0510(0.66)$ & $-.1002(1.20)$ & $-.0596(0.71)$ \\
\hline Homemaker & $-.0354(1.93)$ & $.0066(0.32)$ & $-.0279(1.51)$ & $.0150(0.72)$ & $-.1102(5.83)$ & $-.0677(3.14)$ & $-.1406(6.12)$ & $-.1088(4.44)$ \\
\hline Student & $.4141(5.51)$ & $.3224(4.20)$ & $.2681(3.53)$ & $.2118(2.75)$ & $.2025(2.62)$ & $.0340(0.43)$ & $.2356(2.75)$ & $.0247(0.29)$ \\
\hline Unemployed & $-.1722(8.46)$ & $-.0428(1.85)$ & $-.1666(8.14)$ & $-.0600(2.58)$ & $-.0674(3.15)$ & $.1738(7.08)$ & $-.3499(13.55)$ & $-.1498(5.39)$ \\
\hline Retired & $-.0892(5.14)$ & $-.0679(3.47)$ & $-.0604(3.43)$ & $-.0479(2.43)$ & $-.2201(12.24)$ & $-.2062(10.16)$ & $-.2226(10.02)$ & $-.1828(7.69)$ \\
\hline Farmer & $-.2591(7.36)$ & $-.2083(5.22)$ & $-.1874(5.37)$ & $-.1856(4.68)$ & $-.4208(11.53)$ & $-.3427(8.32)$ & $-.4239(9.59)$ & $-.3726(7.98)$ \\
\hline Fisherman & $-.0987(0.50)$ & $-.1320(0.60)$ & $.2000(1.02)$ & $.1952(0.90)$ & $-.0221(0.11)$ & $-.0260(0.11)$ & $-.5545(2.20)$ & $-.5713(2.13)$ \\
\hline Professional & $.1447(4.13)$ & $.1020(2.58)$ & $.0805(2.30)$ & $.0583(1.47)$ & $.3413(9.34)$ & $.2896(6.94)$ & $.2365(5.29)$ & $.2137(4.50)$ \\
\hline Shopkeeper & $-.0329(1.32)$ & $-.0171(0.60)$ & $-.0257(1.04)$ & $-.0108(0.38)$ & $.0779(3.02)$ & $.0862(2.90)$ & $.0178(0.56)$ & $-.0094(0.28)$ \\
\hline Business proprietor & $.0375(1.13)$ & $.0121(0.32)$ & $.0143(0.43)$ & $-.0043(0.12)$ & $.3133(9.04)$ & $.2671(6.78)$ & $.2642(6.18)$ & $.2180(4.77)$ \\
\hline Empd. professional & $.1083(3.66)$ & $.0569(1.75)$ & $.1120(3.78)$ & $.0803(2.47)$ & $.2223(7.12)$ & $.1355(3.92)$ & $.2264(5.85)$ & $.1480(3.64)$ \\
\hline General mgmt & $.1640(4.31)$ & $.1272(2.92)$ & $.1348(3.51)$ & $.0950(2.17)$ & $.2302(5.85)$ & $.1340(2.95)$ & $.3875(7.83)$ & $.3203(6.07)$ \\
\hline Desk employee & $.0631(3.40)$ & $.0663(3.15)$ & $.0472(2.54)$ & $.0503(2.39)$ & $.0721(3.74)$ & $.0536(2.44)$ & $.0458(1.94)$ & $.0284(1.13)$ \\
\hline Traveling worker & $.0258(0.96)$ & $.0252(0.83)$ & $-.0047(0.18)$ & $-.0063(0.21)$ & $.1356(4.84)$ & $.1436(4.50)$ & $.0370(1.07)$ & $.0235(0.64)$ \\
\hline Service workers & $-.0422(2.18)$ & $-.0454(2.07)$ & $-.0335(1.72)$ & $-.0383(1.74)$ & $.0488(2.42)$ & $.0534(2.32)$ & $.0243(0.98)$ & $.0095(0.36)$ \\
\hline Supervisor & $-.1080(2.59)$ & $-.0957(1.98)$ & $-.0244(0.59)$ & $.0026(0.06)$ & $-.0648(1.50)$ & $-.0641(1.28)$ & $.0066(0.13)$ & $-.0130(0.23)$ \\
\hline Skilled manual & $-.0704(3.86)$ & $-.0574(2.78)$ & $-.0369(2.02)$ & $-.0160(0.78)$ & $-.0719(3.79)$ & $-.0351(1.63)$ & $-.1154(4.98)$ & $-.0992(4.01)$ \\
\hline Married & $-.0438(3.42)$ & $-.1087(7.41)$ & $-.0465(3.62)$ & $-.1111(7.57)$ & $-.2285(17.11)$ & $-.3427(22.26)$ & $.0059(0.36)$ & $-.0794(4.41)$ \\
\hline Living as married & $-.0218(1.30)$ & $-.0485(2.56)$ & $.0154(0.92)$ & $-.0127(0.67)$ & $.0913(5.17)$ & $.0524(2.61)$ & $.2435(10.99)$ & $.2207(9.25)$ \\
\hline Divorced & $-.1214(5.98)$ & $-.0807(3.53)$ & $-.0892(4.37)$ & $-.0520(2.27)$ & $-.0604(2.86)$ & $.0105(0.44)$ & $-.0211(0.82)$ & $.0410(1.48)$ \\
\hline Separated & $-.0785(2.26)$ & $-.0024(0.06)$ & $-.0433(1.24)$ & $.0001(0.00)$ & $.0380(1.04)$ & $.1202(2.91)$ & $.0253(0.57)$ & $.0852(1.80)$ \\
\hline Widowed & $-.0348(1.77)$ & $-.0266(1.20)$ & $-.0451(2.26)$ & $-.0462(2.06)$ & $-.2552(12.59)$ & $-.2605(11.35)$ & $-.0426(1.74)$ & $-.0044(0.17)$ \\
\hline Belgium & $-.3270(13.12)$ & $-.3317(11.44)$ & $-.1187(4.68)$ & $-.1595(5.43)$ & $.2593(10.15)$ & $.2989(9.93)$ & $.1800(5.80)$ & $.1593(4.74)$ \\
\hline Bulgaria & $.2122(5.88)$ & $.6864(17.75)$ & $.6647(18.04)$ & $1.0273(26.01)$ & $-.3157(8.37)$ & $.5173(12.75)$ & $-.4646(10.36)$ & $.4203(8.82)$ \\
\hline
\end{tabular}




\begin{tabular}{|c|c|c|c|c|c|c|c|c|}
\hline Croatia & $-.1509(4.19)$ & $-.0566(1.49)$ & $.1982(5.45)$ & $.2246(5.88)$ & $.0765(2.02)$ & $.3013(7.54)$ & $.1426(3.22)$ & $.4676(10.13)$ \\
\hline Cyprus & $-.8493(16.54)$ & $-.9129(17.29)$ & $-.3879(7.66)$ & $-.5087(9.77)$ & $.2896(5.70)$ & $.2481(4.72)$ & $1.0663(16.89)$ & $1.3438(20.56)$ \\
\hline Czech & $.1033(3.02)$ & $.1450(4.03)$ & $.3946(11.57)$ & $.3714(10.34)$ & $-.0144(0.40)$ & $.0914(2.41)$ & $.1454(3.49)$ & $.0384(0.89)$ \\
\hline East Germany & $-.5925(22.24)$ & $-.5337(16.83)$ & $-.6807(24.45)$ & $-.6763(20.46)$ & $-.2950(11.00)$ & $-.1412(4.39)$ & $-.4160(12.80)$ & $-.2058(5.79)$ \\
\hline Estonia & $1.1382(31.82)$ & $1.2831(34.11)$ & $1.2997(35.81)$ & $1.3702(35.92)$ & $.6421(17.21)$ & $.9339(23.53)$ & $.8317(18.25)$ & $1.2139(25.58)$ \\
\hline Finland & $.4106(16.93)$ & $.2582(9.17)$ & $.6297(25.52)$ & $.4264(14.87)$ & $.6797(26.72)$ & $.5604(18.76)$ & $.4954(15.92)$ & $.4136(12.26)$ \\
\hline Greece & $-.5529(21.75)$ & $-.5137(17.23)$ & $-.3399(13.19)$ & $-.3586(11.89)$ & $.0693(2.64)$ & $.3453(11.20)$ & $.0956(2.97)$ & $.2697(7.71)$ \\
\hline Hungary & $.1444(4.07)$ & $.3748(10.02)$ & $.3728(10.49)$ & $.5062(13.51)$ & $.0314(0.84)$ & $.4611(11.65)$ & $.1077(2.49)$ & $.6243(13.78)$ \\
\hline Ireland & $.6633(26.36)$ & $.5098(17.30)$ & $.9641(38.02)$ & $.7708(26.02)$ & $.8581(33.18)$ & $.7793(25.53)$ & $1.0534(32.12)$ & $.9904(27.92)$ \\
\hline Italy & $-.0966(3.85)$ & $-.0024(0.09)$ & $.2124(8.36)$ & $.2693(9.13)$ & $.7019(27.05)$ & $.7908(25.84)$ & .4969 (15.59) & $.6210(17.96)$ \\
\hline Latvia & $.3341(9.48)$ & $.5381(14.48)$ & $.9425(26.76)$ & $1.0672(28.71)$ & $.4124(11.13)$ & $.8205(20.80)$ & $.4771(10.86)$ & $.9836(21.31)$ \\
\hline Lithuania & $.7039(19.56)$ & $.9195(24.23)$ & $1.4142(38.46)$ & $1.5498(39.97)$ & $.3486(9.22)$ & .7629 (18.98) & $.3308(7.40)$ & $.8426(17.98)$ \\
\hline Luxembourg & $-.0392(1.33)$ & $-.1869(5.36)$ & $-.1065(3.50)$ & $-.2719(7.57)$ & $.3717(12.26)$ & $.2367(6.50)$ & $.4776(13.07)$ & $.3217(8.07)$ \\
\hline Malta & $-.2176(4.20)$ & $-.2520(4.74)$ & $.1570(3.04)$ & $.0601(1.14)$ & $.3609(6.87)$ & $.3433(6.35)$ & $.5864(9.66)$ & $.6571(10.61)$ \\
\hline Netherlands & $-.1666(6.71)$ & $-.3647(12.52)$ & $.2334(9.30)$ & $-.0006(0.02)$ & $.2141(8.43)$ & $.0308(1.03)$ & $.3388(10.93)$ & $.2403(7.13)$ \\
\hline Poland & $.2184(6.00)$ & $.3241(8.47)$ & $.5216(14.56)$ & $.5540(14.68)$ & $.2721(7.16)$ & $.5026(12.47)$ & $-.1493(3.37)$ & $.1291(2.80)$ \\
\hline Portugal & $-.4662(18.09)$ & $-.4349(14.29)$ & $-.3092(11.79)$ & $-.2527(8.23)$ & $-.2748(10.36)$ & $-.0419(1.34)$ & $.5516(17.01)$ & $.8370(23.60)$ \\
\hline Romania & $.5398(14.11)$ & $.8658(21.55)$ & $.4709(12.23)$ & $.6939(17.12)$ & .4295 (10.78) & $1.0253(24.31)$ & $.6149(13.07)$ & $1.2583(25.48)$ \\
\hline Slovakia & $-.1874(5.36)$ & $-.0076(0.21)$ & $.4146(11.92)$ & $.5137(13.99)$ & $-.1950(5.36)$ & $.1520(3.95)$ & $.0773(1.32)$ & $.1372(2.29)$ \\
\hline Slovenia & $.0386(1.08)$ & $-.0115(0.31)$ & $.0443(1.23)$ & $-.0643(1.71)$ & $.1894(5.15)$ & $.1585(4.08)$ & $-.2430(5.85)$ & $.1741(4.01)$ \\
\hline Spain & $.4554(18.19)$ & $.3578(12.21)$ & $.6354(25.07)$ & $.4992(16.82)$ & $.7092(27.37)$ & $.7410(24.22)$ & $.1905(4.46)$ & $.2488(5.63)$ \\
\hline Sweden & $.3511(14.17)$ & $.2350(8.14)$ & $.5797(23.18)$ & .4554 (15.64) & $.9136(35.52)$ & $.7816(25.80)$ & $.8418(26.37)$ & $.8604(24.84)$ \\
\hline Turkey & $.8676(21.72)$ & $.9566(23.01)$ & $.8859(22.43)$ & $.9024(21.91)$ & $.6698(15.84)$ & $.8543(19.30)$ & $.7608(23.91)$ & $.6430(18.59)$ \\
\hline Turkish Cyprus & $1.2484(24.82)$ & $1.3015(25.14)$ & $1.3926(27.75)$ & $1.3765(26.64)$ & $1.0391(19.32)$ & $1.1983(21.32)$ & $.2221(4.66)$ & $.5001(10.12)$ \\
\hline West Germany & $-.2751(11.14)$ & $-.2565(8.93)$ & $-.1166(4.62)$ & $-.1199(4.09)$ & $-.1441(5.72)$ & $-.0879(2.97)$ & $-.3021(9.94)$ & $-.2264(6.88)$ \\
\hline cut1 & -.4833 & .5491 & -.1550 & .7494 & -2.3905 & -.6778 & -3.7664 & -2.0448 \\
\hline cut2 & 1.3971 & 2.4703 & 1.5584 & 2.4985 & .4734 & 2.3522 & -1.4665 & .35400 \\
\hline $\mathrm{N}$ & 225,315 & 179,205 & 224,578 & 178,295 & 232,551 & 184,890 & 155,518 & 139,559 \\
\hline Pseudo $\mathrm{R}^{2}$ & .0535 & .0489 & .0440 & .0537 & .0711 & .1059 & .0958 & .1225 \\
\hline
\end{tabular}

Notes: excluded categories: middle manager; single and ALS $<16$. T-statistics in parentheses. Ordered logits. Equations also include year dummies. Source for columns 1-6: Eurobarometers \#65.2 (2006); \#64.2 (2005); \#63.4 (2005); \#62.0 (2004); \#61.0 (2004)*;\#60.1 (2003); \#58.1 (2002); \#56.2 (2001); \#54.1 (2000); \#52.0 (1999); \#50.0 (1998)*; \#48.0 (1997); \#46.0 (1996)* and \#44.1 (1995)*. For columns 7 \& 8 Eurobarometers \#65.2 (2006); \#63.4 (2005); \#62.0 (2004); \#61.0 (2004)*; \#57.1 (2002); \#55.1 (2001); $\# 53.0$ (2000); and \#47.1 (1997). * = does not include life satisfaction data in the survey. 
Table 19. Expectations twelve months ahead - UK

\begin{tabular}{cccccccc} 
& $\begin{array}{c}\text { Your life } \\
\text { in general }\end{array}$ & $\begin{array}{c}\text { Economic } \\
\text { situation }\end{array}$ & $\begin{array}{c}\text { Employment } \\
\text { situation }\end{array}$ & $\begin{array}{c}\text { Annual pp changes in } \\
\text { Unemployment }\end{array}$ & \multicolumn{2}{c}{$\begin{array}{c}\text { Economic situation } \\
\text { Inflation }\end{array}$} & $\begin{array}{c}\text { GORI } \\
1995\end{array}$ \\
38 & 25 & 21 & -1.0 & 0.6 & -6.9 & -17.5 \\
1996 & 42 & 25 & 27 & -0.5 & -0.1 & -3.6 & -6.9 \\
1997 & 39 & 29 & 33 & -1.1 & -0.7 & 8.3 & 7.3 \\
1998 & 39 & 21 & 23 & -0.9 & -0.2 & -6.9 & -17.0 \\
1999 & 36 & 25 & 31 & -0.2 & -0.3 & -4.4 & -5.3 \\
2000 & 41 & 24 & 28 & -0.5 & -0.5 & -10.8 & -9.2 \\
2001 & 46 & 21 & 23 & -0.7 & 0.4 & -14.8 & -22.2 \\
2002 & 46 & 16 & 19 & 0.3 & 0.1 & -8.1 & -22.8 \\
2003 & 49 & 17 & 20 & -0.2 & 0.1 & -18.4 & -28.3 \\
2004 & 44 & 18 & 20 & -0.2 & -0.1 & -12.9 & -21.8 \\
2005 & 44 & 18 & 20 & -0.1 & 0.8 & -11.8 & -20.6 \\
2006 & 43 & 21 & 21 & 0.7 & 0.2 & -17.9 & -28.3
\end{tabular}

Source: columns 1-3 as in Table 18. Columns 4 and 5 ONS. Columns 6 and 7, MORI General Economic Optimism Index (www.IPSOSMORI.com - economic optimism over the next 12 months), Gfk NOP Consumer Confidence Survey (Q4. How do you think the general economic situation in this country will develop over the next 12 months?) 
Figure 1. Average Happiness and Real GDP per Capita for repeated cross-sections of Americans.

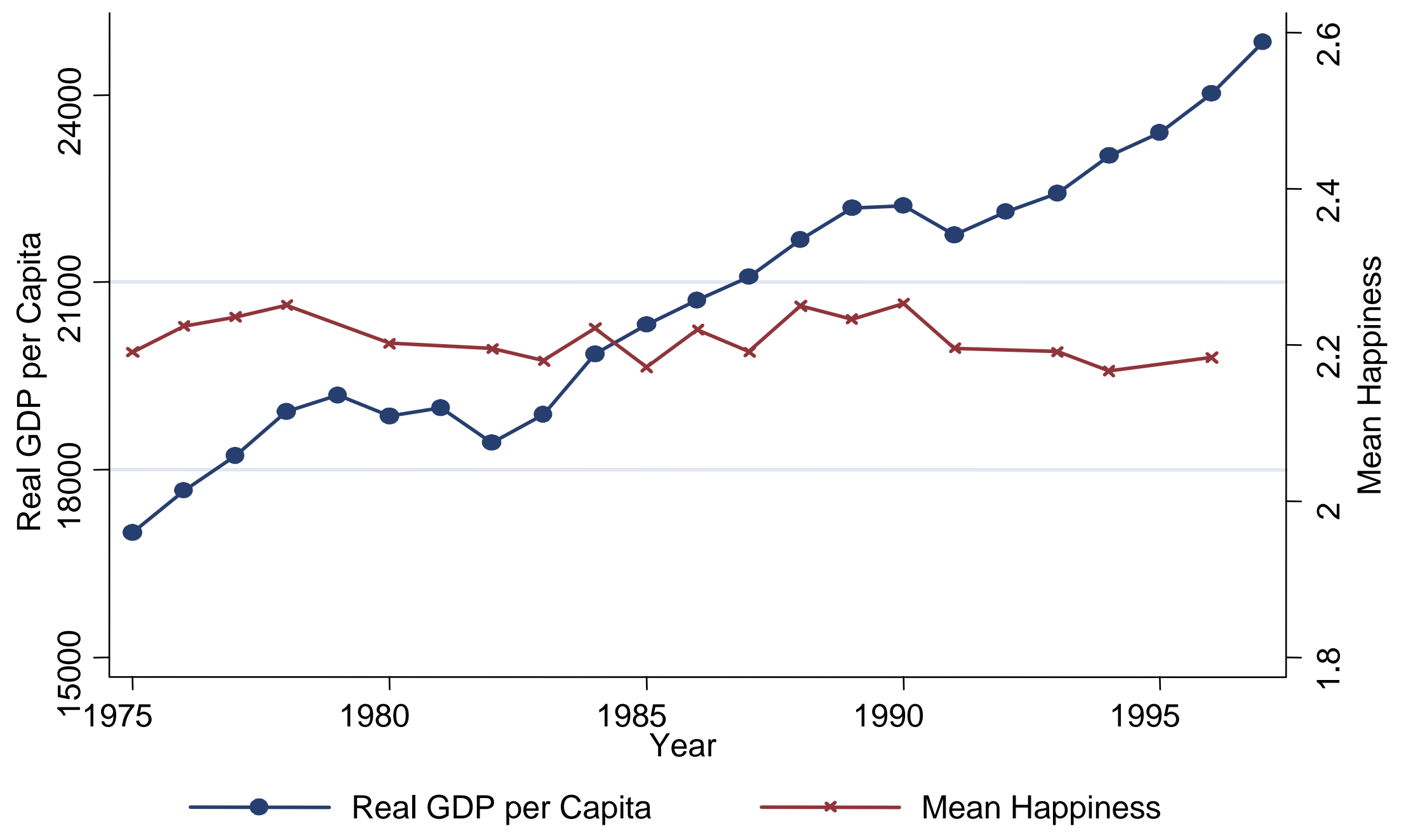


Figure 2a. Mean Life Satisfaction scores, 1973-2006

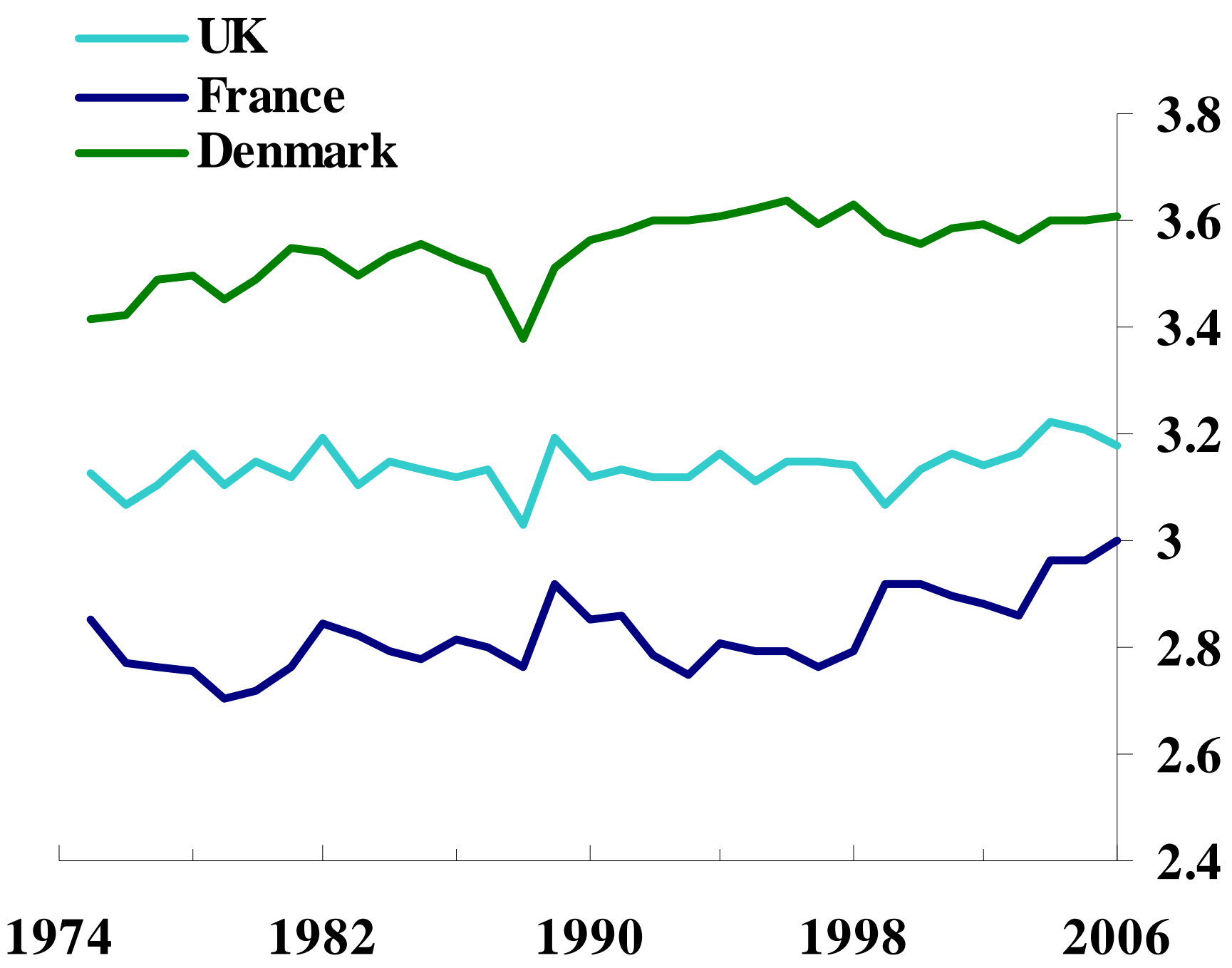


Figure 2b. Mean Life Satisfaction scores, 1973-2006

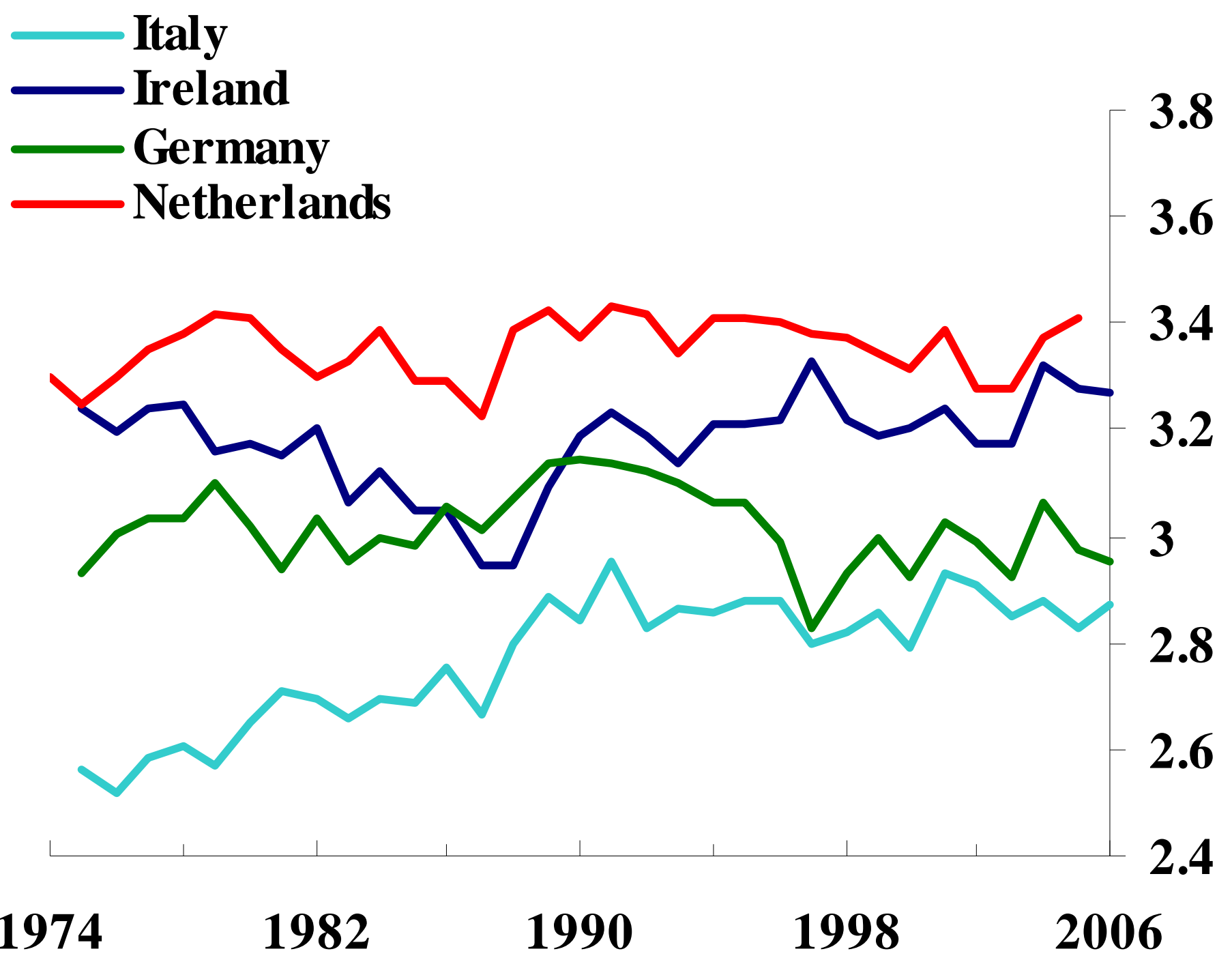


Figure 3: Life satisfaction and the unemployment rate (2003)

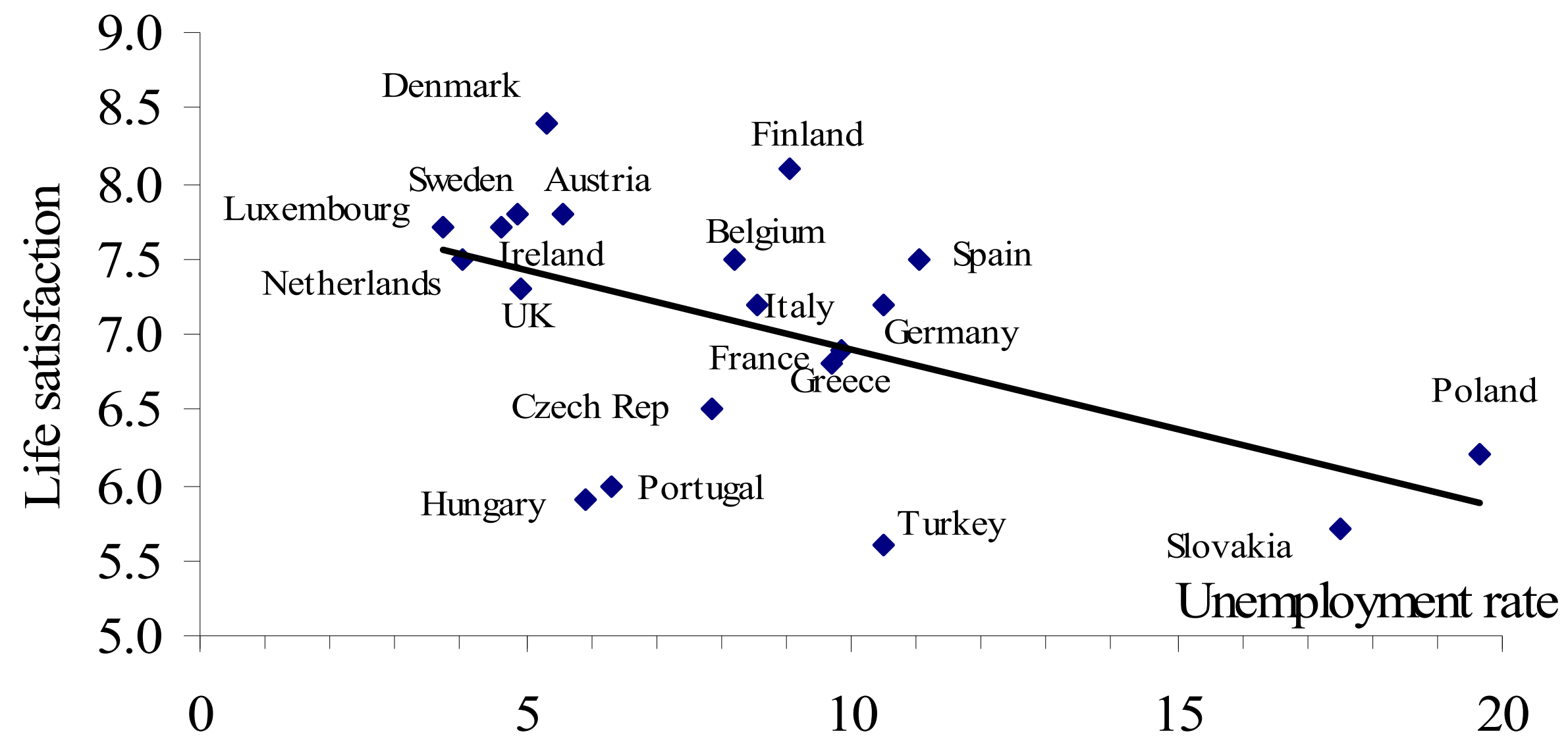


Figure 4: Life satisfaction and inflation (HICP, 2003)

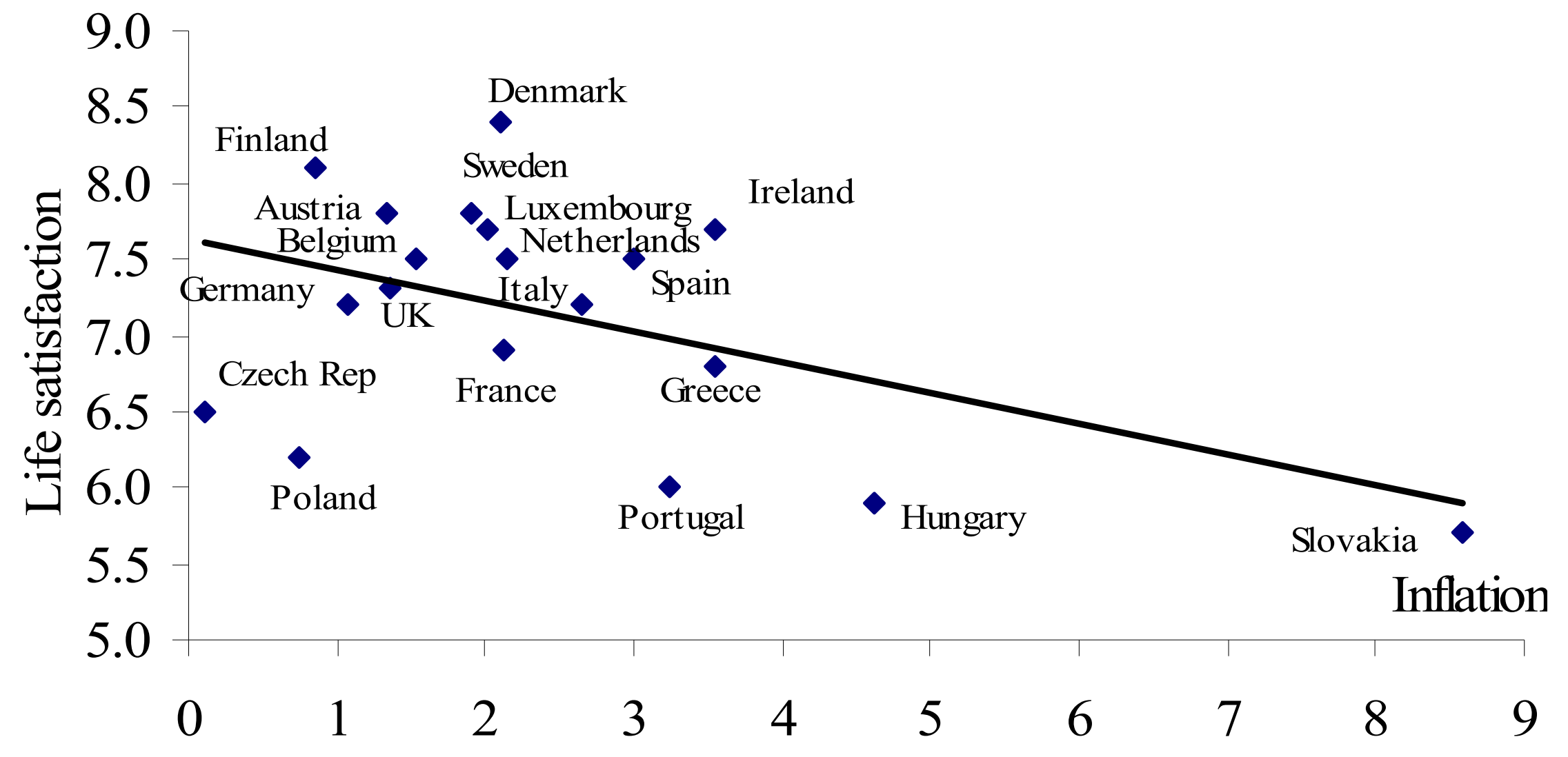


Figure 5: Life Satisfaction and GDP per capita

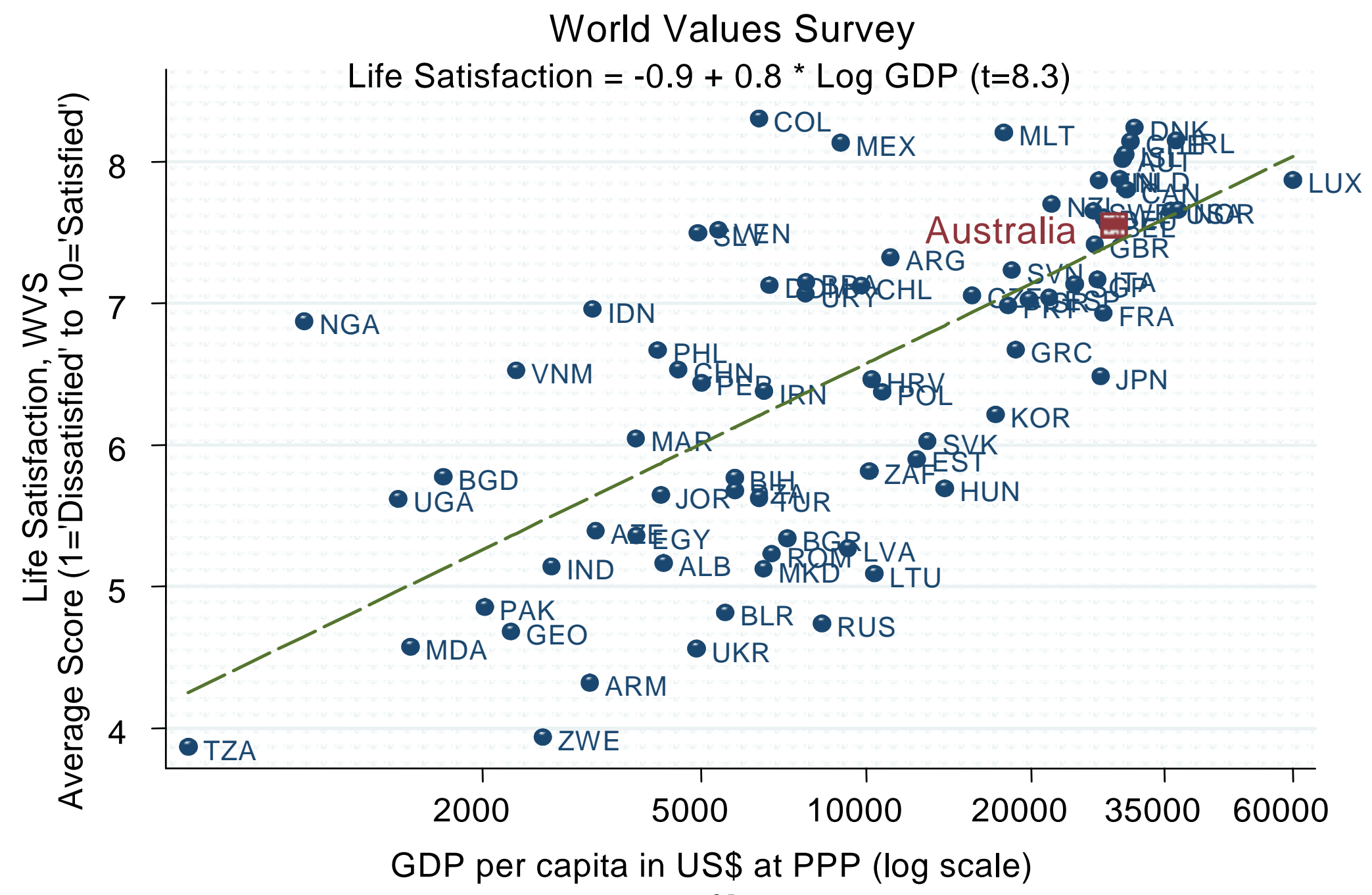




\section{Figure 6: $1995 / 2000$ World Values Survey result}

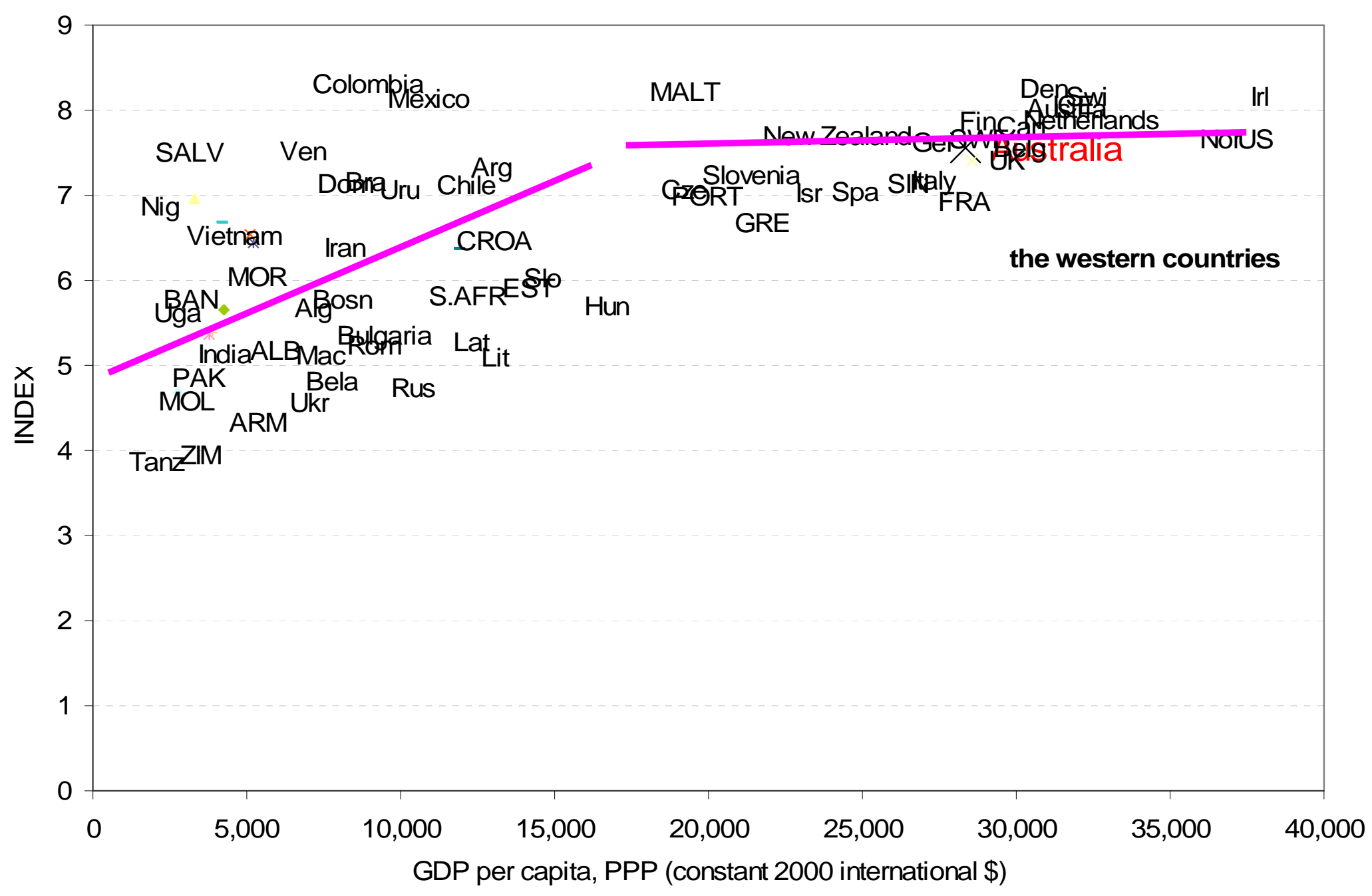


Figure 7a: Proportion of UK Eurobarometer respondents saying the economic situation in 12 months will improve (inverted) and the change in unemployment and inflation rates.

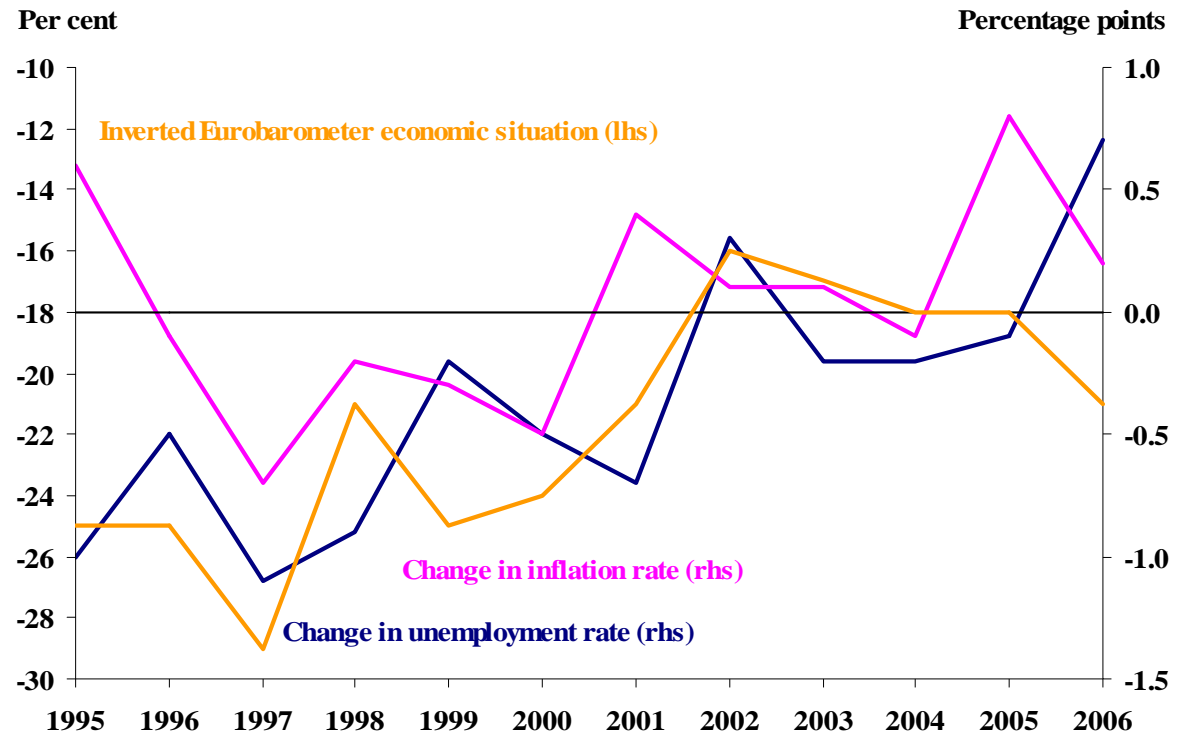

Figure 7b: Proportion of UK Eurobarometer respondents saying the economic situation in 12 months will improve (inverted) compared with other measures of economic confidence

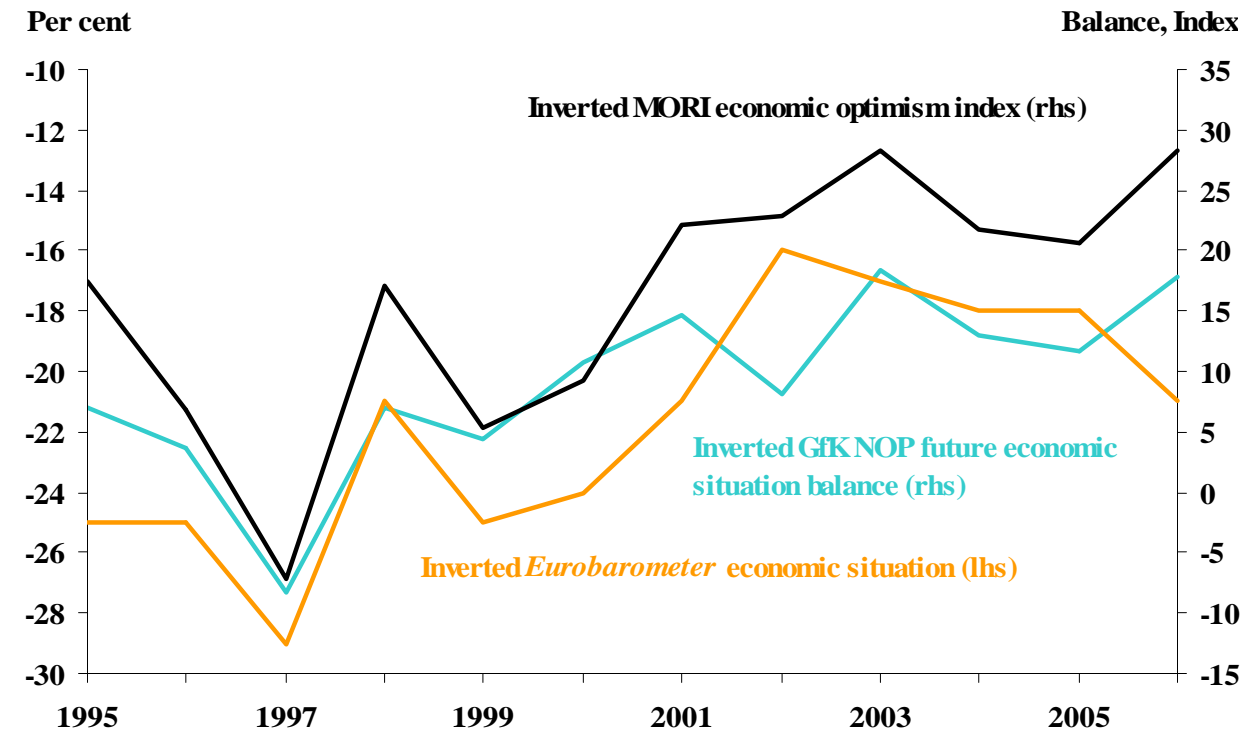

Source: Eurobarometers 1995-2006, MORI General Economic Optimism Index (www.IPSOSMORI.com - economic optimism over the next 12 months), Gfk NOP Consumer Confidence Survey (Q4. How do you think the general economic situation in this country will develop over the next 12 months?) 
Appendix Table A. OLS happiness equations from the EQLS 2003

$\begin{array}{lcc} & \text { Life satisfaction } & \text { Happiness } \\ \text { Household income (euros) } & .0001754(11.72) & .0000915(6.60) \\ \text { Age } & -.0475(9.31) & -.0346(7.33) \\ \text { Age }^{2} & .0005(11.50) & .0003(8.08) \\ \text { Male } & -.1844(6.41) & -.1525(5.72) \\ \text { 16-19 yrs schooling } & .1797(4.61) & .1972(5.46) \\ \text { 20+ years schooling } & .2712(6.21) & .2491(6.15) \\ \text { Still studying } & .1016(0.89) & .2236(2.13) \\ \text { No schooling } & .2341(1.31) & .0604(0.36) \\ \text { Self-employed } & .2506(1.98) & .0820(0.70) \\ \text { Manager } & .4361(3.55) & .2269(2.00) \\ \text { Other white collar } & .2251(1.86) & .0405(0.36) \\ \text { Manual } & .1189(1.01) & .0050(0.05) \\ \text { Home worker } & .1785(1.45) & .1114(0.98) \\ \text { Unemployed } & -.6847(5.49) & -.5874(5.08) \\ \text { Retired } & .2864(2.39) & .1786(1.61) \\ \text { Student } & .5249(3.33) & .2678(1.84) \\ \text { Very good health } & -.3109(6.05) & -.4164(8.74) \\ \text { Good health } & -.7433(14.94) & -.8651(18.76) \\ \text { Fair health } & -1.3280(24.70) & -1.5188(30.50) \\ \text { Poor health } & -2.2910(35.29) & -2.5683(42.67) \\ \text { Married/living together } & .3389(7.78) & .6240(15.46) \\ \text { Separated/Divorced } & -.2355(3.99) & -.2292(4.19) \\ \text { Widowed } & -.1400(2.27) & -.1989(3.48) \\ \text { Constant } & 8.0087(41.49) & 8.7142(48.12)\end{array}$

Notes: equations also include 27 country dummies. T-statistics in parentheses 
Appendix Table B. OLS coefficients by country from life satisfaction and happiness equations

\begin{tabular}{|c|c|c|c|c|c|c|c|c|c|c|c|c|}
\hline & Male & Age min & $\begin{array}{c}\text { ALS } \\
16-19\end{array}$ & $\begin{array}{l}\text { ALS } \\
\geq 20\end{array}$ & Time & Married & Widowed & $\begin{array}{l}\text { Self- } \\
\text { employed }\end{array}$ & Student & Retired & Unempd & $\mathrm{N}$ \\
\hline Belgium & -.03 & 48 & .03 & .12 & -.004 & .15 & -.12 & -.05 & .14 & -.05 & -.31 & 57,637 \\
\hline Denmark & -.06 & 44 & .03 & .10 & .003 & .14 & -.04 & -.03 & .05 & -.13 & -.27 & 56,882 \\
\hline France & -.02 & 46 & .10 & .24 & .005 & .12 & -.08 & * & .33 & .13 & -.24 & 58,335 \\
\hline Germany & $*$ & 42 & .02 & .10 & -.004 & .11 & -.04 & .05 & .12 & -.05 & -.52 & 85,631 \\
\hline Greece & -.01 & 56 & .16 & .28 & * & .12 & -.12 & * & .29 & * & -.21 & 47,801 \\
\hline Ireland & -.09 & 37 & .14 & .27 & $*$ & .12 & -.07 & .04 & .22 & -.04 & -.55 & 55,839 \\
\hline Italy & $*$ & 56 & .09 & .12 & .011 & .15 & -.07 & .03 & .13 & * & -.39 & 59,032 \\
\hline Luxembourg & -.04 & 41 & .06 & .11 & .003 & .15 & -.08 & * & .12 & * & -.41 & 23,297 \\
\hline Netherlands & -.08 & 46 & .07 & .12 & .001 & .16 & -.16 & * & .10 & -.04 & -.37 & 56,710 \\
\hline Portugal & .04 & 62 & .08 & .15 & -.003 & .05 & -.12 & .08 & .16 & -.04 & -.29 & 38,354 \\
\hline Spain & -.02 & 51 & .04 & .11 & .006 & .11 & -.11 & .03 & .11 & * & -.27 & 38,969 \\
\hline Sweden & -.02 & 49 & .06 & .08 & .019 & .17 & * & .01 & * & -.09 & -.25 & 18,427 \\
\hline UK & -.06 & 38 & .10 & .19 & .002 & .14 & -.08 & * & .18 & -.07 & -.40 & 76,346 \\
\hline Europe & -.03 & 46 & .08 & .16 & .001 & .11 & -.10 & .01 & .17 & -.05 & -.37 & 768,993 \\
\hline USA & -.04 & 41 & .09 & .19 & $*$ & .28 & * & .05 & .17 & $*$ & -.23 & 46,035 \\
\hline
\end{tabular}

Source: Eurobarometers and GSS 2006. OLS, dependent variable is 4-step life satisfaction and 3 step happiness in the USA. Excluded categories single, ALS $<=15$ years. Also includes dummies for home worker, divorced. * means t-statistic $<2$

Data for the US are from 1972-2006 (excl. 1979, 1981, 1992, 1995, 1997, 1999, 2001, 2003 and 2005) and from the Eurobarometers from $1973-2006$ (excl. 1974 and 1996). Data for Greece was 1981-2006; for Spain and Portugal was 1985-2006 and for Sweden and Finland, 1995-2006 (all excl. 1996). Age minimum calculated from the always highly significant, age and age squared coefficients. Europe also includes Austria (1995-2006), Czech Republic, Hungary, Poland, Slovakia, Slovenia, Bulgaria, Romania, Croatia, Turkey and Estonia (all 2004-2006) plus Norway (1990-1995) and includes country dummies for each. 